University of Pennsylvania Carey Law School

Penn Law: Legal Scholarship Repository

Faculty Scholarship at Penn Law

$2-27-2011$

\title{
Report on Offense Grading In New Jersey
}

\author{
Paul H. Robinson \\ University of Pennsylvania Carey Law School \\ Rebecca Levenson \\ Nicholas Feltham \\ Andrew Sperl \\ Kristen-Elise Brooks
}

See next page for additional authors

Follow this and additional works at: https://scholarship.law.upenn.edu/faculty_scholarship

Part of the Criminal Law Commons, Criminology Commons, Legislation Commons, Policy Design, Analysis, and Evaluation Commons, and the Public Law and Legal Theory Commons

\section{Repository Citation}

Robinson, Paul H.; Levenson, Rebecca; Feltham, Nicholas; Sperl, Andrew; Brooks, Kristen-Elise; Koprowski, Agatha; Peake, Jessica; Probber, Benjamin; and Trainor, Brian, "Report on Offense Grading In New Jersey" (2011). Faculty Scholarship at Penn Law. 340.

https://scholarship.law.upenn.edu/faculty_scholarship/340

This Report is brought to you for free and open access by Penn Law: Legal Scholarship Repository. It has been accepted for inclusion in Faculty Scholarship at Penn Law by an authorized administrator of Penn Law: Legal Scholarship Repository. For more information, please contact PennlawIR@law.upenn.edu. 


\section{Authors}

Paul H. Robinson, Rebecca Levenson, Nicholas Feltham, Andrew Sperl, Kristen-Elise Brooks, Agatha Koprowski, Jessica Peake, Benjamin Probber, and Brian Trainor 


\title{
REPORT ON OFFENSE GRADING IN NEW JERSEY
}

\author{
University of Pennsylvania Criminal Law Research Group
}

Table of Contents

I. Examples of Offense Grading Irrationalities and Inconsistencies in Current New Jersey Law .........................2

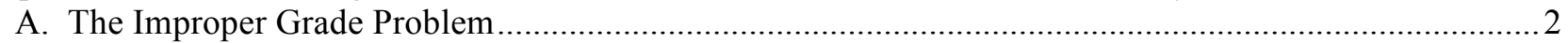

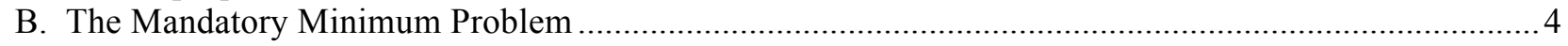

C. The Problem of Inconsistent Grades Among Similar Offenses......................................................... 6

D. The Problem of Too Broad Offenses: Failing to Distinguish Conduct of Significantly ......................... 7

Different Seriousness Contained Within a Single Offense Grade ................................................................

E. The Problem of Too Few Offense Grading Categories ...................................................................

F. The Problem of Codifying Criminal Offenses Outside of the Criminal Code....................................... 12

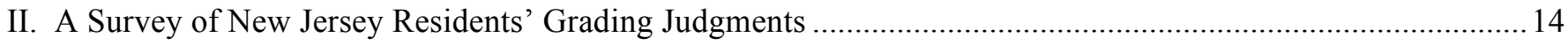

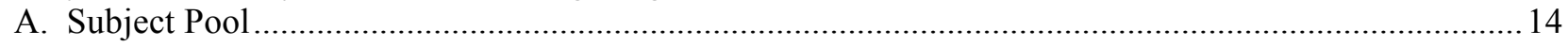

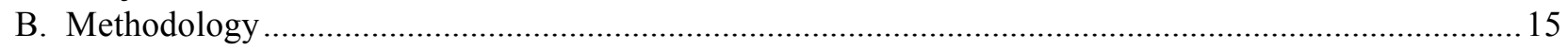

III. Why Should We Care About Getting Offense Grades Right? ............................................................. 18

A. Offense Grades that Conflict with Community Views Undermine the Criminal................................. 18

Law's Moral Credibility and, Thereby, Its Ability to Fight Crime ...................................................... 18

B. Offense Grades Tell Citizens the Relative Importance of Conflicting Duties ..................................... 18

C. Offense Grades Express the Legislature's Values, Avoiding Ad Hoc Delegation of Such ................... 19

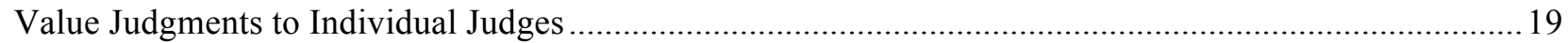

D. Offense Grades Insure a Fixed Rule for All Offenders ................................................................... 19

E. Improper Offense Grades May be Costly and Inefficient .............................................................20

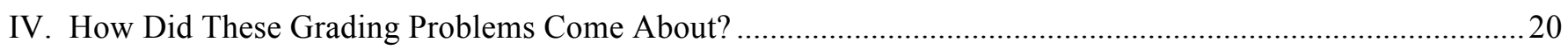

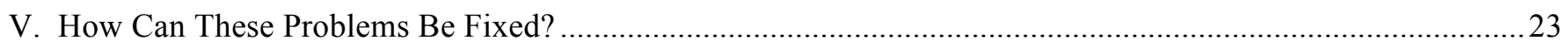

V. How Can Such Grading Irrationalities Be Avoided In The Future? .............................................................25

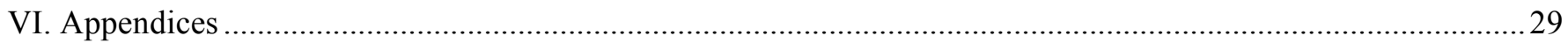

Appendix A: More Examples of the Improper Grade Problem ..........................................................29

Appendix B: More Examples of the Mandatory Minimum Problem .......................................................... 38

Appendix C: More Examples of the Problem of Failing to Distinguish Conduct of Significantly

Different Seriousness Contained Within A Single Offense Grade ............................................................39

Appendix D: More Examples of the Problem of Too Few Grading Categories ....................................... 41

Appendix E: Increasing Rate of Amendments to New Jersey Criminal Law ............................................43

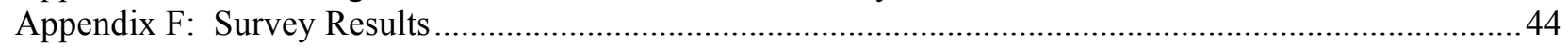

Appendix G: The Survey Instrument and Questions.......................................................................... 51

- Professor Paul H. Robinson, Rebecca Levenson \& Nicholas Feltham (co-directors), Andrew Sperl (technical director), Kristen-Elise Brooks, Agatha Koprowski, Jessica Peake, Benjamin Probber, and Brian Trainor. 
In 1978, the New Jersey Legislature enacted its Code of Criminal Justice (codified as Title 2C), followed by a host of amendments to the Code before it took effective in 1979. ${ }^{1}$ New Jersey's code, along with the criminal codes of at least 33 other states, is modeled on the Model Penal Code of the American Law Institute. Title 2C, like other Model-Code-based codes, is meant to be relatively comprehensive; that is, included in its offenses and suboffenses ${ }^{2}$ is most criminal conduct, and certainly all serious criminal conduct. Yet extensive legislative activity since 1979 has dramatically increased the number of offenses and suboffenses beyond the 243 of the original code. Today's Title 2C contains an additional 407 offenses and suboffenses - for a total of 650 . In addition, there are now 904 criminal offenses in New Jersey law defined outside of the Code of Criminal Justice. ${ }^{3}$

Unfortunately, the stream of code amendments have paid little attention to already-existing offenses or their grades, resulting in a system of offenses marked by inconsistent and contradictory grading differences, as well as offense grades that seriously conflict with the values of New Jersey residents.

One of the greatest drafting advances of modern criminal codes - one now used even by jurisdictions (and countries) that did not otherwise have a modern criminal code - is the creation of a system of offense grading. Under grading schemes, each offense is categorized into one of several grading categories that distinguished offenses according to their level of seriousness. New Jersey adopted four degrees of crimes (1st through 4th degree) ${ }^{4}$ and two degrees of disorderly person offenses (disorderly persons and petty disorderly persons). ${ }^{5}$ Later, a "super grade" category was added to mark out the most egregious crimes. ${ }^{6}$ As will become apparent from the analysis below, New Jersey Code's grading of scheme, probably flawed from the start, has become increasingly irrational in its categorizations and unfair in its application.

\section{EXAMPLES OF OFFENSE GRADING IRRATIONALITIES AND INCONSISTENCIES IN CURRENT NeW Jersey LAW}

Current law contains serious grading problems of at least six different sorts.

\section{A. The Improper Grade Problem}

The most common problem is setting the grade of an offense at a level that is inappropriate as compared to other offenses of that grade. Consider the following

\footnotetext{
${ }^{1}$ Enactment of the Code of Criminal Justice as Title 2C, 1978 N.J. Laws, c. 95, (codified as amended) at N.J. Stat. Ann. §2C (West 2010).

${ }^{2}$ By "suboffense," we mean a course of defined conduct with an offense grade different from that of other conduct defined in the same code section. In other words, a criminal code might have three suboffenses of robbery, or five suboffenses of theft, depending upon the number different grades of the offense that it recognizes.

${ }^{3}$ N.J. Stat. Ann. § 2 C (West 2010). Each suboffense was counted as a separate offense, meaning that any conduct that was graded differently from base offense was counted separately.

${ }^{4}$ N.J. Stat. Ann. §2C:43-6 (West 2010) (sentence of imprisonment for crimes, ordinary terms).

${ }^{5}$ N.J. Stat. Ann. §2C:43-8 (West 2010) (sentence of imprisonment for disorderly persons offenses).

${ }^{6}$ See, e.g., N.J. Stat. Ann. §2C:11-3b (West 2010) (sentence of imprisonment for murder, including imprisonment of 30 years to life imprisonment without the possibility of parole).
} 
examples from this study of the grading views of New Jersey residents ${ }^{7}$ :

- Opening a bottle of ketchup at the supermarket and placing it back on the shelf without purchasing it $^{8}$ is graded by New Jersey residents as similar in seriousness to fighting with another by mutual consent, a petty disorderly persons offense, which has a maximum sentence of 30 days imprisonment, ${ }^{9}$ but under current law the offense is graded as a $3 \mathrm{rd}$ degree crime, which has a maximum sentence of 5 years imprisonment. ${ }^{10}$

- Pulling a driver of a car stopped at a red light from his seat and driving the car away $^{11}$ is graded by New Jersey residents as similar in seriousness to intentionally slashing another person's shoulder with a knife, a 3rd degree crime, which has a maximum sentence of 5 years imprisonment, ${ }^{12}$ but under current law the carjacking offense is graded as a 1st degree crime, and has a maximum sentence of 30 years imprisonment. ${ }^{13}$

- Knowingly paying a contractor $\$ 80,000$ to fix a house "under the table" (without collecting and paying proper taxes ${ }^{14}$ is graded by New Jersey residents as similar in seriousness to a minor theft offense, graded as a disorderly persons offense, which has a maximum sentence of 6 months imprisonment, ${ }^{15}$ but under current law the offense is a 2 nd degree crime, which has a maximum sentence of 10 years imprisonment. $^{16}$

- Knowingly creating a fake label for a prescription hair loss medication bottle because one does not want others to know one is taking the medication ${ }^{17}$ is graded by New Jersey residents as similar in seriousness to intentionally annoying someone by making anonymous phone calls to them at 2 am, a petty disorderly persons offense, which has a maximum sentence of 30 days imprisonment, ${ }^{18}$ but under current law the offense is graded as a 3rd degree crime, which has a maximum sentence of 5 years imprisonment. ${ }^{19}$

\footnotetext{
${ }^{7}$ Note that throughout the Report, where we indicate the grades that surveyed New Jersey residents gave, we rely on the mean of the survey responses, rounded according to normal convention.

${ }^{8}$ N.J. Stat. Ann. §2C:40-17a (West 2010).

${ }^{9}$ Mean $=1.99$, Median $=2, \mathrm{SD}=0.92($ Appendix F, item A3).

${ }^{10}$ N.J. Stat. Ann. §2C:43-6.a(3) (West 2010).

${ }^{11}$ N.J. Stat. Ann. §2C:15-2a (West 2010).

${ }^{12}$ Mean $=5.23$, Median $=5, \mathrm{SD}=0.66($ Appendix $\mathrm{F}$, item A2).

${ }^{13}$ N.J. Stat. Ann. §2C:15-2b (West 2010) ("Carjacking is a crime of the first degree and upon conviction thereof a person may, notwithstanding the provisions of paragraph (1) of subsection a. of N.J. Stat. $\$ 2$ C: 43-6, be sentenced to an ordinary term of imprisonment between 10 and 30 years.").

${ }^{14}$ N.J. Stat. Ann. $\$ 34: 20-5 a(2)$ (West 2010).

${ }^{15}$ Mean $=3.46$, Median $=4, \mathrm{SD}=1.52($ Appendix F, item A1).

${ }^{16}$ N.J. Stat. Ann. §2C:43-6a(2) (West 2010).

${ }^{17}$ N.J. Stat. Ann. §24:6B-29a (West 2010).

${ }^{18}$ Mean $=1.54$, Median $=1, \mathrm{SD}=0.96$ (Appendix F, item D19).

${ }^{19}$ N.J. Stat. Ann. §2C:43-6.a(3) (West 2010).
} 
- Writing a letter from prison to a friend, pressuring him to join a gang and to begin selling drugs for $\mathrm{it}^{20}$ is graded by the New Jersey residents as similar in seriousness to intentionally giving another person a black eye, a disorderly persons offense, which has a maximum sentence of 6 months imprisonment, ${ }^{21}$ but under current law the offense is graded as a 2 nd degree crime, which has a maximum sentence of 10 years imprisonment. ${ }^{22}$

In some instances, the current law's grading is improper in the opposite direction, leaving an offense with a grade that is lower than what the New Jersey residents consider appropriate. For example:

- A lawyer purposely turning over secret court transcripts from a police informant to members of a gang, with the intent of having the gang members attack the police informant ${ }^{23}$ is graded by New Jersey residents as similar in seriousness to manslaughter, a 2nd degree crime, which has a maximum sentence of 10 years imprisonment, ${ }^{24}$ but under current law the offense is graded as a 4 th degree crime, which only has a maximum sentence of 18 months imprisonment. ${ }^{25}$

- A public utility company knowingly importing enriched uranium (a radioactive material) into New Jersey ${ }^{26}$ is graded by residents as the same seriousness as beating a person to intentionally cause paralysis, a 2 nd degree crime, which has a maximum sentence of 10 years imprisonment, ${ }^{27}$ but under current law the importing radioactive material offense is graded as a 4th degree crime, which has a maximum sentence of 18 months imprisonment. ${ }^{28}$

Appendix A provides many more examples of the problem. To produce a comprehensive list of offenses with these kinds of grading problems, one would need to undertake an empirical survey of all of New Jersey's criminal laws rather than just the 108 offenses tested in this study.

\section{B. The Mandatory Minimum Problem}

There are good reasons to be generally skeptical about mandatory minimum sentences. They often subvert the criminal law's obligation to give punishment according to the level of an offender's blameworthiness, because they prevent the system from taking into account factors that make the offense or offender at hand significantly less blameworthy than the paradigm instance of the offense. If one believes in the value of doing justice, then one must be as concerned about over-punishment as with under-

\footnotetext{
${ }^{20}$ N.J. Stat. Ann. §2C:33-28(e) (West 2010).

${ }^{21}$ Mean $=3.42$, Median $=4, \mathrm{SD}=1.65$ (Appendix F, item A9).

${ }^{22}$ N.J. Stat. Ann. §2C:43-6a(2) (West 2010).

${ }^{23}$ N.J. Stat. Ann. §2B:21-10 (West 2010).

${ }^{24}$ Mean $=5.60$, Median $=6, \mathrm{SD}=1.30($ Appendix F, item A4).

${ }^{25}$ N.J. Stat. Ann. §2C:43-6.a(4) (West 2010).

${ }^{26}$ N.J. Stat. Ann. §26:2D-22 (West 2010).

${ }^{27}$ Mean $=5.57$, Median $=6, \mathrm{SD}=1.25($ Appendix F, item A5).

${ }^{28}$ N.J. Stat. Ann. §2C:43-6.a(4) (West 2010).
} 
punishment. Mandatory minimums can often lead to over-punishment, especially in cases with facts different from the typical case.

Admittedly, there also are reasons to be concerned about the improper exercise of judicial discretion that imposes less punishment than an offender deserves. Avoiding such discretion is the primary consideration that makes minimum sentences seem appealing. However, such concerns can be addressed with a coherent sentencing guideline system, without the need for the sledgehammer of mandatory minimums that inevitably guarantee some degree of injustice. That is, the solution to the improper exercise of discretion problem is not the elimination all discretion through mandatory minimums but rather the guidance of that discretion.

However, even if one were to see some value in having mandatory minimums for some offenses, the minimums contained in New Jersey current law often produce serious distortions in the grading system, as illustrated by the examples below and in Appendix B. While the grading problems discussed in Part I.A. above allow judges to impose improper levels of punishment, these mandatory minimums commonly demand that a judge impose an improper level of punishment. For example:

- New Jersey residents graded knowingly conspiring with two other people to import LSD into New Jersey and overseeing other people who sell the $\operatorname{LSD}^{29}$ as a crime similar in seriousness to intentionally slashing another person's shoulder with a knife, which has a maximum penalty of 5 years. ${ }^{30}$ Yet, current law sets the mandatory minimum for the offense at 25 years. ${ }^{31}$

- New Jersey residents graded knowingly growing 15 marijuana plants in a greenhouse $^{32}$ as a crime similar in seriousness to intentionally giving another person a black eye, which has a maximum penalty of 6 months. ${ }^{33}$ Yet, current law sets the mandatory minimum for the offense at 3 years and 4 months. ${ }^{34}$

- New Jersey residents graded knowingly hacking into a company's computer network to access company e-mail and then posting the e-mails online publicly ${ }^{35}$ as similar in seriousness to intentionally causing another person emotional distress, which has a maximum penalty of 18 months. ${ }^{36}$ Yet, current law sets the mandatory minimum for the computer hacking offense at least at 20 months. ${ }^{37}$

\footnotetext{
${ }^{29}$ N.J. Stat. Ann. §2C:35-3 (West 2010).

${ }^{30}$ Mean $=4.79$, Median $=5, \mathrm{SD}=1.38($ Appendix F, item B1).

${ }^{31}$ N.J. Stat. Ann. $\$ 2 \mathrm{C}: 35-3$ (West 2010).

${ }^{32}$ N.J. Stat. Ann. §2C:35-4 (West 2010).

${ }^{33}$ Mean $=3.01$, Median = 3, SD = 1.52 (Appendix F, item B5).

${ }^{34}$ N.J. Stat. Ann. $\$ 2 C: 35-4$ (West 2010). The statute provides that the minimum term will be "fixed at, or between, one-third and one-half of the sentence imposed." Since this is a first-degree crime with a sentence range of 10 to 20 years, even the lowest minimum term of one-third of the sentence imposed would result in a mandatory minimum of 3 years and 4 months.

${ }^{35}$ N.J Stat. Ann. $\$ 2 \mathrm{C}: 20-31$ (West 2010).

${ }^{36}$ Mean $=4.06$, Median $=4, \mathrm{SD}=1.09$ (Appendix F, item B3).

${ }^{37}$ N.J. Stat. Ann. $\$ 2 C: 20-31$ (West 2010). The statute provides that "[t]he period of imprisonment shall include a minimum term of one-third to one-half of the sentence imposed." Since this is a 2nd degree crime with a sentence range of 5 to 10 years, even the lowest minimum term of one-third of the sentence imposed would result in a mandatory minimum of 20 months.
} 
- New Jersey residents graded agreeing to accept new sneakers, valued at $\$ 100$, in return for not reporting a crime ${ }^{38}$ as most similar in seriousness to stealing $\$ 40$, which has a maximum penalty of 6 months. ${ }^{39}$ Yet, current law sets the mandatory minimum for the offense at 2 years. ${ }^{40}$

When the mandatory minimum requires the sentencing judge to impose a sentence that exceeds the maximum sentence available to the offense grade seen by the New Jersey residents as most appropriate for the offense, it demands an improper sentence in every case. In other instances, the mandatory sentence requires a sentence equal to the statutory maximum of the grade that residents think is appropriate. Such provisions invite regular injustice, since not every instance of the offense can be the most egregious, to which the maximum penalty would properly apply.

\section{The Problem of Inconsistent Grades Among Similar Offenses}

Another problem that commonly appears in modern criminal codes is the problem of assigning different grades for no rational reason to two offenses involving similar conduct and intention. Sometimes a new offense simply defines specific conduct within a more general, already existing offense. Adding an unnecessary offense is problematic, first, because it may improperly permit liability and punishment for multiple offenses when the offender's conduct is a single harm or evil. Second, a serious problem of inconsistent grading can occur: the grades of the two offenses are often different, even though there is little reasonable basis for a grading difference. The New Jersey Criminal Code is not as bad in this respect as the codes of many other states, but the reason for this may be that it suffers another, perhaps more serious flaw: it contains fewer grading categories than other states (discussed below in Part I.E), resulting in many of these redundant offenses falling within the same broad grading category. Despite the fewer grading categories - thus the broader scope of each category - the New Jersey Code still offers examples of the inconsistent grade problem:

- Selling the fur of a domestic cat or dog is a 4 th degree crime, ${ }^{41}$ punishable by a maximum term of 18 months. ${ }^{42}$ Selling the flesh of the same domestic cat or dog for human consumption is a disorderly persons offense and punishable by a fine of not less than $\$ 100$ and a term of imprisonment of not less than 30 days. ${ }^{43}$ It is not clear why these two offenses should be graded so differently.

- A person who purposely starts a fire that recklessly places a building in danger of damage is guilty of a 3rd degree crime, and punishable by a maximum term of 5

\footnotetext{
${ }^{38}$ N.J. Stat. Ann. §2C:29-4 (West 2010).

${ }^{39}$ Mean $=3.33$, Median $=3, \mathrm{SD}=1.20$ (Appendix F, item B4).

${ }^{40}$ N.J. Stat. Ann. $\$ 2 C: 43-6.5 . b(16)$ (West 2010).

${ }^{41}$ N.J. Stat. Ann. $\S 4: 22-25.3$ (West 2010) (Prohibition of sale of dog or cat fur or hair).

${ }^{42}$ N.J. Stat. Ann. \$2C:43-6a(4) (West 2010).

${ }^{43}$ N.J. Stat. Ann. $\$ 4: 22-25.4$ (West 2010) (Prohibition of sale of dog or cat flesh).
} 
years in prison. ${ }^{44}$ If the same person starts the fire in a place of public worship, the individual is guilty of a 1st degree crime - punishable by imprisonment for a minimum term of 15 years without parole. ${ }^{45}$ One might defend an aggravation for targeting a church, but the dramatic two-grade increase, with its tripling of maximum punishment, is inconsistent with the more typical one degree increase that is used in all other instances of "bias intimidation" offenses. ${ }^{46}$

\section{The Problem of Too Broad Offenses: Failing to Distinguish Conduct of Significantly Different Seriousness Contained Within a Single Offense Grade}

Modern criminal law codification reflects an overwhelming commitment to grading offenses in proportion to their relative level of seriousness. The reasons for this nearly universal codification trend are detailed in Part III of this Report. However, in New Jersey law, the definitions of crimes - most typically new crimes - commonly ignore the importance of distinguishing between significantly different types of conduct. Instead, new crimes often define single offenses very broadly, thereby assigning the same grade to wide range of conduct of widely different seriousness.

This tendency toward too broad offenses forces the grade for the offense to be set quite high in order to adequately punish the most serious conduct, thereby exposing to improperly high punishment the less serious conduct included within the broad offense. Conversely, a focus on the less serious conduct in grading the offense might yield an offense grade too low to properly punish the more serious conduct included within the offense. By failing to enact a more nuanced grading scheme that recognizes important differences between the seriousness of conduct, the Legislature fails to provide its judgments as to the relative seriousness of this conduct. This failure has the effect of delegating such important value judgments to individual sentencing judges on an ad hoc basis, a result that can be both unfair to offenders and unwise for the society. ${ }^{47}$

Our survey of New Jersey residents confirms that the problem of too-broad offenses is substantial. For example:

- A person who purchases non-Energy-Star-efficient appliances for a prison when Energy-Star-efficient appliances are available at comparable prices ${ }^{48}$ is punished under the same statute as a person who fails to publicly solicit bids for a $\$ 500,000$ state project. ${ }^{49}$ Under current law, both courses of conduct are graded as 4 th degree crimes, with a maximum sentence of 18 months,${ }^{50}$ but New Jersey residents graded the first scenario as a disorderly persons offense, ${ }^{51}$ with a maximum sentence of 6 months, and the second scenario as a 3rd degree crime,

\footnotetext{
${ }^{44}$ N.J. Stat. Ann. §2C:17-1b(2) (West 2010) (Arson and related offenses).

${ }^{45}$ N.J. Stat. Ann. §2C:17-1g. (West 2010) (Arson and related offenses).

${ }^{46}$ N.J. Stat. Ann. §2C:16-1c (West 2010) (“[B]ias intimidation is a crime one degree higher than the most serious underlying crime.”).

${ }^{47}$ See Paul H. Robinson and Markus D. Dubber, The American Model Penal Code: A Brief Overview, New CRiminal LaW Review, Vol. 10, No. 3, 319, 327-28 (discussing negative effects of having broad judicial discretion without a systematic code of criminal offenses).

${ }^{48}$ N.J. Stat. Ann. §52:34-18 (West 2010) (Violations involving contracts in excess of \$2500).

${ }^{49} \mathrm{Id}$.

${ }^{50} \mathrm{Id}$.

${ }^{51}$ Mean $=2.50$, Median $=2, \mathrm{SD}=1.58($ Appendix F, item D5).
} 
with a maximum sentence of 5 years. ${ }^{52}$

- A waiter who does not declare $\$ 500$ in cash tips on his tax returns is punished under the same offense as an executive who sets up an off-shore account in which he hides $\$ 100,000$ to avoid paying taxes. ${ }^{53}$ Under current law, both courses of conduct are graded as 3rd degree crimes, with a maximum sentence of 5 years, ${ }^{54}$ but New Jersey residents graded the first scenario as a disorderly persons offense, with a maximum sentence of 6 months, ${ }^{55}$ and the second scenario as a $3 \mathrm{rd}$ degree crime, with a maximum sentence of 5 years. ${ }^{56}$

- A spectator at a single dogfight and an organizer who collects bets for weekly fights that he organizes are punished under the same offense. ${ }^{57}$ Both courses of conduct are graded as $3 \mathrm{rd}$ degree crimes, with a maximum sentence of 5 years, ${ }^{58}$ but New Jersey residents graded the first scenario as a disorderly persons offense, with a maximum sentence of 6 months, ${ }^{59}$ and the second scenario as a $3 \mathrm{rd}$ degree crime, with a maximum sentence of 5 years. ${ }^{60}$

- A person who holds a fundraiser for an organization believed to be a nonprofit working in interfaith dialogue, but which actually supports Al-Qaeda training camps in Pakistan, ${ }^{61}$ and a person holding a fundraiser to send money directly to Al-Qaeda ${ }^{62}$ would both be punished for a 2 nd degree crime, with a maximum sentence of 10 years, ${ }^{63}$ but the New Jersey residents graded the first scenario as a 4th degree crime, with a maximum sentence of 18 months, ${ }^{64}$ and the second scenario as a 2 nd degree crime, with a maximum sentence of 10 years. ${ }^{65}$

- Under the statute restricting the participation of sex offenders in youth service organizations, a 30-year-old man who was convicted as an 18-year old for having sex with his girlfriend when she was 15 is punished if he coaches his son's basketball team. ${ }^{66} \mathrm{~A}$ man who has been convicted of multiple rapes of 10-year-

\footnotetext{
${ }^{52}$ Mean $=4.53$, Median $=5, \mathrm{SD}=1.49($ Appendix F, item D6).

${ }^{53}$ N.J. Stat. Ann. $\S 54: 52-8$ (West 2010) (Failure to file returns or reports with intent to defraud, evade, or not make timely payments).

${ }^{54} \mathrm{Id}$.

${ }^{55}$ Mean $=2.63$, Median $=3, \mathrm{SD}=1.21($ Appendix F, item D7).

${ }^{56}$ Mean $=4.55$, Median $=5, \mathrm{SD}=1.17$ (Appendix F, item D8).

${ }^{57}$ N.J. Stat. Ann. $\S 4: 22-24$ (West 2010) (Fighting or baiting animals or creatures).

${ }^{58} I d$.

${ }^{59}$ Mean $=2.77$, Median $=3, \mathrm{SD}=1.43($ Appendix F, item D3).

${ }^{60}$ Mean $=4.82$, Median $=5, \mathrm{SD}=1.35$ (Appendix F, item D4).

${ }^{61}$ N.J. Stat. Ann. $\S 2$ C: 38-5b (West 2010) (Soliciting or providing material support or resources for terrorism).

${ }^{62} I d$.

${ }^{63}$ N.J. Stat. Ann. $§ 2 C: 38-5 c$ (West 2010) (Soliciting or providing material support or resources for terrorism).

${ }^{64}$ Mean $=4.30$, Median $=5, \mathrm{SD}=2.57($ Appendix F, item D9). It is important to note that a significant number of respondents $(\mathrm{N}=60)$ did not grade this as a crime at all.

${ }^{65}$ Mean $=5.87$, Median $=6, \mathrm{SD}=1.63$ (Appendix F, item D10).

${ }^{66}$ This conduct would constitute aggravated criminal sexual contact under N.J. Stat. Ann. §2C:14-3a (because the act of sexual contact occurred under N.J Stat. Ann. §2C:14-2a(2)). Accordingly, the offender
} 
old girls is punished under the same law when he works as a fourth grade teacher. ${ }^{67}$ Both offenses would be punished as 3 rd degree crimes, with a maximum sentence of 5 years. ${ }^{68}$ However, New Jersey residents graded the first scenario as a petty disorderly persons offense, with a maximum sentence of 30 days, ${ }^{69}$ and the second scenario as a 2 nd degree crime, with a minimum sentence of 5 years. ${ }^{70}$

Other examples are given in Appendix C. To produce a comprehensive list of offenses with these kinds of grading problems, one would need to test all of New Jersey's criminal laws, not just the 108 included in this study.

\section{E. The Problem of Too Few Offense Grading Categories}

Not only does New Jersey have many offenses that are too broad, but its general grading scheme is constructed in such a way as to ensure that similar problems will exist for most, if not all, offenses. New Jersey recognizes seven offense categories - four classes of crimes (without distinction between felonies and misdemeanors); two classes of disorderly persons offenses; and one category for "super-grade" crimes, such as aggravated murder. ${ }^{71}$ Among the states that have adopted grading schemes, the New Jersey scheme is an outlier. Of the 37 American states that have established a grading scheme, ${ }^{72}$ only four states have fewer grading categories than New Jersey. ${ }^{73}$ Of the 34 states that have adopted the Model Penal Code, New Jersey is the only state without a general distinction between felony and misdemeanor crimes. ${ }^{74}$ Other states make use of as many as 16 different grading categories. ${ }^{75}$

will have committed a "sex offense" as proscribed by N.J. Stat. Ann. §2C:7-2b.1, as is thus categorized as an "excluded sex offender" (under N.J. Stat. Ann. §2C:7-22) for the purposes of N.J. Stat. Ann. \$2C:7-23a.

${ }^{67}$ This conduct would constitute aggravated sexual assault under N.J. Stat. Ann. §2C:14-2a(1).

Accordingly, the offender will have committed a "sex offense" as proscribed by N.J. Stat. Ann. §2C:7-

$2 \mathrm{~b}(1)$, as is thus categorized as an "excluded sex offender" (under N.J. Stat. Ann. §2C:7-22) for the purposes of N.J. Stat. Ann. §2C:7-23a.

${ }^{68}$ N.J. Stat. Ann. $\$ 2$ C:7-23 (West 2010) (Prohibitions upon sex offender participation in any youth serving organization).

${ }^{69}$ Mean $=2.27$, Median $=1, \mathrm{SD}=1.86($ Appendix F, item D1).

${ }^{70}$ Mean $=5.85$, Median $=6, \mathrm{SD}=1.86($ Appendix F, item D2).

${ }^{71}$ See N.J. Stat. Ann. §2C:43-6 (West 2010); N.J. Stat. Ann. §2C:43-8 (West 2010).

72 The following fourteen states do not rely upon an offense grading scheme: CA, GA, LA, MA, MD, MI, MS, MT, OK, RI, and VT. By grading scheme, we mean something more than simply using terms of felonies, misdemeanors, and some form of lesser violations. (These lesser forms of offenses most often do not carry jail-time. See, e.g., A.R.S. §13-105.30; A.C.A. §5-1-108; Cal. Penal Code §19.6; C.G.S.A. §53a27; 11 Del.C. §4207; FL ST §755.081(5); HRS §701-107(5); I.C. §18-111; 730 ILCS 5/5-1-17 and 730 ILCS 5/5-1-2; K.S.A. 8-2118 and K.S.A. 21-4012; K.R.S. §532.020(4); V.A.M.S. 557.016; N.C. St. §143.1; NDCC §12.1-32-01; Ohio Rev. Code Ann §2929.26(D); VA Code §18.2-8. But see Alabama Criminal Code $§ 13 A-1-2$ and C.R.S.A. §18-1.3-503. Nevertheless, since many of New Jersey's own disorderly persons offenses and petty disorderly persons offenses do not actually carry a penalty of imprisonment either, consideration of these categories can provide valuable insight into how New Jersey's grading scheme compares with those of other states.).

73 The states are: ME, MN, NH, and WA. Of the other 33 states that have adopted modern codes based upon the Model Penal Code, 22 have defined more offense grades than New Jersey.

${ }^{74}$ Though the New Jersey Code references both "misdemeanors" and "high misdemeanors," "high misdemeanors" actually encompass first, second, or third degree crimes and "misdemeanors" refer to 
The problem with few grading categories is that each offense is then necessarily too broad, with the kind of problems discussed in the previous subsection to this Report. Too few grading categories means that a New Jersey offense must necessarily cover a broad range of offense conduct of varying seriousness. The practice creates a systematic problem: the low number of grades does not allow meaningful distinctions to be made between conduct of importantly different levels of seriousness. ${ }^{76}$

The systemic problem invites grading errors that undermines the code's moral credibility with the community, making it all the more difficult for the criminal justice system to effectively fight crime. The lack of distinctions among offenses of different seriousness also fails to signal to citizens the relative importance of conflicting duties and fails to express the value judgments of the legislature (thereby forcing an undesirable amount of discretion ad hoc to individual judges). ${ }^{77}$ (More on the importance of proper offense grading in Part III below.)

The result is that New Jersey's Code assigns the same grade to conduct that while it may have the same subject matter - New Jersey residents believe is importantly different. For example:

- Knowingly selling a cow known to have "mad cow" disease ${ }^{78}$ and knowingly selling a purse made out of $\operatorname{dog}$ fur $^{79}$ are each graded as 4 th degree crimes. New Jersey residents, however, view these crimes as very different, grading knowingly selling a cow with mad cow disease as similar to an owner of dangerous pit bulls causing the death of a neighbor's child by refusing to fix the broken lock on their cage, a 2 nd degree crime, ${ }^{80}$ and knowingly selling dog fur as similar to running naked in a public place, a disorderly persons offense. ${ }^{81}$

- Hacking into an ex-girlfriend's computer to get her bank account details ${ }^{82}$ and possessing a device designed to intercept private telephone calls ${ }^{83}$ are each graded as 3rd degree crimes. New Jersey residents, however, view these crimes as quite different, grading the hacking into the computer as being similar to intentionally

crimes of the fourth degree. N.J. Stat. Ann. §2C:1-4d (West 2010). Even within New Jersey Code's Title $2 \mathrm{C}$, two different definitions of these terms exist. In Section $2 \mathrm{C}: 43-1$, high misdemeanors are said to "constitute for the purpose of sentence a crime of the third degree." N.J. Stat. Ann. §2C:43-1 (West 2010); N.J. Stat. Ann. §2C: 1-4 (West 2010). In contrast, Section 2C:1-4 states that any offense listed outside the code which is labeled a misdemeanor but provides "a maximum penalty of 6 months' imprisonment or less, whether or not in combination with a fine, such provision shall constitute a disorderly persons offense." This provision also defines "high misdemeanor" as "crimes of the first, second, or third degree and reference to the term 'misdemeanor' shall mean all crimes." N.J. Stat. Ann. §2C: 1-4 (West 2010).

75 See, e.g., Neb. Rev. Stat. Ann. § 28-105 (LexisNexis 2010) (Felonies); Neb. Rev. Stat. Ann. § 28-106 (LexisNexis 2010) (Misdemeanors).

${ }^{76}$ See Part I.D, supra at 7.

${ }^{77}$ See Part III, infra at 18-20.

${ }^{78}$ N.J. Stat. Ann. $\S 4: 22-22$ (West 2010) (Use or disposal of animals having contagious diseases).

${ }^{79}$ N.J. Stat. Ann. $\$ 4: 22-25.3$ (West 2010) (Prohibition of sale of dog or cat fur or hair).

${ }^{80}$ Mean $=5.62$, Median $=6, \mathrm{SD}=1.16($ Appendix F, item E1 $)$

${ }^{81}$ Mean $=2.93$, Median $=3, \mathrm{SD}=1.63$ (Appendix F, item E2).

${ }^{82}$ N.J. Stat. Ann. §2C:20-25c (West 2010) (Computer-related theft).

${ }^{83}$ N.J. Stat. Ann. §2A:156A-5 (West 2010) (Possession of intercepting devices). 
causing another person emotional distress, a 4th degree crime ${ }^{84}$ and possessing the device to intercept calls as being similar to intentionally giving another person a black eye, a disorderly persons offense. ${ }^{85}$

- Knowingly lending a gun which has been used by various community members to commit muggings ${ }^{86}$ and knowingly purchasing and carrying a hand gun without a permit ${ }^{87}$ are each graded as 2 nd degree crimes. New Jersey residents, however, view these acts differently, grading knowingly lending a community gun as similar to intentionally slashing another person's shoulder with a knife, a 3rd degree crime, ${ }^{88}$ and purchasing and carrying without a permit as similar to intentionally causing another person emotional distress, a 4th degree crime. ${ }^{89}$

- Winning $\$ 100,000$ at a casino by using a calculator that is specifically programmed to count cards ${ }^{90}$ and winning $\$ 80,000$ at a casino by hiding cards in one's sleeve $^{91}$ are each graded as 2 nd degree crimes. New Jersey residents, however, view the two acts differently, grading using the calculator programmed to count cards as similar to stealing $\$ 500$, a 4 th degree crime, ${ }^{92}$ and hiding cards in one's sleeves as similar to stealing $\$ 25,000$, a 3rd degree crime. ${ }^{93}$

More examples of this trend are contained in Appendix D. A grading scheme that included additional grading categories would be able to make more nuanced distinctions, thereby taking fuller advantage of the benefits associated with having a grading scheme.

It may be the lack of specificity caused by too few grading categories that has led lawmakers in some instances to abandon the grading scheme altogether and to create a special punishment range for an offense. A significant minority of offenses - roughly $14 \%$ of those offenses contained within Title $2 \mathrm{C}$ and over $10 \%$ of those offenses located outside of Title $2 \mathrm{C}^{94}$ - discard the normal punishment range given to offense grades and instead specify a special punishment range. In other words, they revert back to the pregrading-scheme world. There are good reasons for adopting a grading scheme, ${ }^{95}$ and lawmakers should stick to this nearly universal feature of modern criminal codes. The solution to the problem of too broad grades is not to abandon the grading scheme entirely but rather to fix it by creating more offense grades.

\footnotetext{
${ }^{84}$ Mean $=4.29$, Median $=4, \mathrm{SD}=1.00($ Appendix $F$, item A25).

${ }^{85}$ Mean $=3.47$, Median $=4, \mathrm{SD}=1.35$ (Appendix F, item E3).

${ }^{86}$ N.J. Stat. Ann. §2C:39-4a (West 2010) (Possession of weapons for unlawful purposes).

${ }^{87}$ N.J. Stat. Ann. §2C:39-5b (West 2010) (Unlawful possession of weapons).

${ }^{88}$ Mean $=5.01$, Median $=5, \mathrm{SD}=1.40($ Appendix F, item E4).

${ }^{89}$ Mean $=3.98$, Median $=4, \mathrm{SD}=1.26($ Appendix F, item A15).

${ }^{90}$ N.J. Stat. Ann. $§ 5: 12-113.1$ (West 2010) (Use of a device to obtain advantage at casino game).

${ }^{91}$ N.J. Stat. Ann. §5:12-113c(1) (West 2010) (Swindling and cheating).

${ }^{92}$ Mean $=3.97$, Median $=5, \mathrm{SD}=1.59($ Appendix F, item E6).

${ }^{93}$ Mean $=4.65$, Median $=5, \mathrm{SD}=1.05$ (Appendix F, item E7).

${ }^{94}$ This is a conservative count of offenses, however; it does include some offenses for which the specified punishment is only a fine.

${ }_{95}$ See Paul H. Robinson and Markus D. Dubber, The American Model Penal Code: A Brief Overview, NEW CRIMINAL LAW REVIEW, Vol. 10, No. 3, 319, 327-28 (discussing negative effects of having broad judicial discretion without a systematic code for criminal offenses).
} 


\section{F. The Problem of Codifying Criminal Offenses Outside of the Criminal Code}

Today's New Jersey Criminal Code, in Title 2C, contains 650 offenses and suboffenses in total. ${ }^{96}$ However, there are an additional 904 criminal offenses that are defined outside of Title 2C. ${ }^{97}$ Codifying criminal offenses outside of the criminal code creates several complications: (1) it encourages gaps and redundancies in the definition of offenses; (2) it exacerbates the problem of inconsistencies in the grading of offenses; and (3) it makes it unrealistic to think that a New Jersey citizen could learn what the criminal law demands of him even if he worked hard to try to find out.

First, the codification of criminal offenses outside of Title $2 \mathrm{C}$ leads to gaps and redundancies in the definition of offenses. Such scattering of offenses throughout the many titles of New Jersey law makes it difficult for legislators to find all existing offenses, let alone taking them into account in setting the scope of new offenses, and allows the same criminal conduct to be punished under different offenses. ${ }^{98}$ For example:

- The bribery offense in Title 19 applies specifically to meals, advertising or entertainment, ${ }^{99}$ but there already exists a general bribery provisions in Title $2 \mathrm{C}$ that punishes giving any benefit as consideration for a vote or exercise of discretion of a public servant in any public election. ${ }^{100}$

- The crime of parental abuse, abandonment, cruelty or neglect of a child is codified in Title $9,{ }^{101}$ but several individual offenses in Title $2 \mathrm{C}$ - such as a parent who willfully fails to provide support to a child ${ }^{102}$ - already cover such conduct.

- The crime of submitting a false claim under an automobile insurance policy is codified in Title $39,{ }^{103}$ even though the same act of insurance fraud is already criminalized as insurance fraud under Title $2 \mathrm{C} .{ }^{104}$

Second, codifying criminal offenses in titles other than Title $2 \mathrm{C}$ can exacerbate the problem of improper grading. For example, separating the parental abuse or neglect of children offenses into different titles has probably contributed to their inconsistent grading.

\footnotetext{
${ }^{96}$ N.J. Stat. Ann. $\S 2 \mathrm{C}$ (West 2010).

${ }^{97}$ N.J. Stat. Ann. (West 2010).

${ }^{98}$ In instances where the same conduct of the defendant could establish the commission of more than one offense, the defendant can be prosecuted for both offenses but, where one offense prohibits a more specific form of the conduct generally prohibited by the other, the defendant can only be convicted of one of the offenses. See N.J. Stat. Ann. §2C:1-8 (West 2010). Even though the code recognizes that these situations exist, the better practice would still be to at least include the offenses within the same title of the code.

${ }^{99}$ N.J. Stat. Ann. §19:34-25j \& k (West 2010) (Bribery).

${ }^{100}$ N.J. Stat. Ann. §2C:27-2a (West 2010) (Bribery in official and political matters).

${ }^{101}$ N.J. Stat. Ann. §9:6-3 (West 2010) (Cruelty and neglect of children).

${ }^{102}$ N.J. Stat. Ann. §2C:24-5 (West 2010) (Willful nonsupport).

${ }^{103}$ N.J. Stat. Ann. §39:6A-15 (West 2010) (Penalties for false and fraudulent misrepresentation).

${ }^{104}$ N.J. Stat. Ann. §2C:21-4.6 (West 2010) (Insurance fraud).
} 
- Though the offense in Title 9 states that any parent who abuses, abandons, is cruel to or neglectful of a child is guilty of a crime of the 4th degree, ${ }^{105}$ a different offense in Title $2 \mathrm{C}$ states that the same conduct as described by the Title 9 offense is a crime of the 2 nd degree. ${ }^{106}$ Such inconsistencies can lead to large disparities in punishment, with a parent charged under the offense in Title 9 facing a prison sentence of up to 18 months, ${ }^{107}$ whereas a parent charged under the offense in Title 2C would face a prison sentence of 5 to 10 years. ${ }^{108}$

Gathering all of the offenses together under Title $2 \mathrm{C}$, the New Jersey legislature would be better equipped to ensure that the penalties associated with each offense properly reflect the seriousness of that offense in relation to other offenses.

Finally, the codification of criminal offenses in different titles of the code also makes it unrealistic to expect that a citizen could find out the criminal law even if he tried. ${ }^{109}$ Without a central code containing all serious offenses, citizens are forced to search the entire body of New Jersey statutory law before they can know if particular conduct is criminalized.

The problem is not merely one of personal or administrative convenience. The doctrine of fair notice in criminal law is founded on the Due Process Clauses of the Fifth and Fourteenth Amendments. ${ }^{110}$ Although the separation of criminal offenses into different titles does not rise to the level of a constitutional violation, such an approach to drafting "commonly does a poor job at this most important function: telling people what they can, must, and must not do, under threat of criminal sanction." "11 The drafters of the New Jersey Criminal Code recognized the importance of fair notice by incorporating it into the code's "purposes" provision: "[ $\mathrm{t}]$ he general purposes of the provisions governing the definition of offenses are: . . . [t] o give fair warning of the nature of the conduct proscribed and of the sentences authorized upon conviction ...."112 In keeping faithful to that purpose, criminal offenses should be organized in a manner that allows citizens to learn what the criminal law requires of them.

By moving all serious offenses into Title $2 \mathrm{C},{ }^{113}$ the legislature would do much to ensure that citizens, public servants, public officials, and they themselves in their future enactments are in a position to know the existing law.

\footnotetext{
${ }^{105}$ N.J. Stat. Ann. $\S 9: 6-3$ (West 2010) (Cruelty and neglect of children).

${ }^{106}$ N.J. Stat. Ann $\S 2 C: 24-4$ (West 2010) (Endangering the welfare of children).

${ }^{107}$ See N.J. Stat. Ann. §2C:43-6.

${ }^{108} \mathrm{Id}$.

${ }^{109}$ Even within Title 2C there are many offenses that are located outside Subtitle 2, which is entitled the "Definition of Specific Offenses." Typically, modern criminal codes endeavor to codify all offenses within the specific offenses section of the code; however, Title 2C contains at least 16 specific offenses in Subtitle 1, which comprises the "General Provisions," and 7 specific offenses in Subtitle 3, which comprises the "Sentencing" provisions.

${ }^{110}$ U.S. CONST. amend. V \& XIV.

${ }^{111}$ See Paul H. Robinson, Fair Notice and Fair Adjudication, 154 U. PA. L. REV. 335, 371 (2005).

112 N.J. Stat. Ann. \$2C:1-2 (West 2010) (Purposes).

${ }^{113}$ When the codification of Title 2C occurred in 1978, several offenses from other titles were re-codified in Title 2C. See N.J. Stat. Ann. T. 2C, Disp Table.
} 


\section{A Survey of NeW Jersey Residents' Grading Judgments}

Throughout the previous Part, we have referred to the judgments of New Jersey residents in a survey. Here we describe that survey and how it was conducted. ${ }^{114}$

\section{A. Subject Pool}

The Research Group surveyed 222 New Jersey residents. Paid respondents were solicited from Amazon.com's Mechanical Turk, ${ }^{115}$ while volunteer participants ${ }^{116}$ were solicited through public notices, local newspapers, Craigslist, ${ }^{117}$ and community internet sites in communities throughout New Jersey, including each of its counties. In all, 154 of the respondents were compensated, while the remaining 68 were unpaid volunteers.

Various methods were used to verify that respondents were New Jersey residents. First, each respondent's IP address was logged, and a freely available online IP geocoding service was used to determine the IP address' geographic origin. Because there are various reasons that IP geocoding may incorrectly report that a response did not originate in New Jersey, additional inquiry was made. If the IP address did not originate in New Jersey, the respondent was contacted where possible and asked to verify his/her New Jersey county of residence. Because some respondents could not be contacted, particularly volunteer respondents for whom no contact information was obtained, the survey was modified during the data collection phase to also ask for the respondent's city or town of residence. Questions about city and county residence were asked at the beginning and end of the survey, respectively, and if the city entered by the respondent matched the county selected by the respondent, the response was validated.

The subject pool had a broad demographic distribution: $30 \%$ were aged between 18 and $24,35 \%$ between 25 and 34, 13\% between 35 and 44, 11\% between 45 and 54 , $10 \%$ between 55 and 64, and 1\% were aged 65 and over. Subjects were narrowly divided between men and women, with $47 \%$ male and $53 \%$ female. The subject pool also was educationally diverse, with $2 \%$ of subjects reporting they had not graduated from high school, 11\% had a high school diploma or GED, 36\% had some college experience, 9\% had a 2 -year college degree, $30 \%$ had a 4 -year college degree, $9 \%$ had a Master's degree, and $3 \%$ had a professional degree.

Respondents identified the New Jersey county in which they resided. Subjects represented 20 of New Jersey's 21 counties: ${ }^{118} \quad 39 \%$ of respondents came from counties in Northern New Jersey, 33\% of respondents came from counties in Central New Jersey,

\footnotetext{
${ }^{114}$ The study was conducted with funding from the University of Pennsylvania Law School and the Drug Policy Alliance - New Jersey Chapter, which we thank for their support.

${ }^{115}$ Mechanical Turk is a service operated by Amazon.com, designed to provide a low-cost pool of labor to complete online tasks. This system coordinates a large pool of paid volunteers who perform paid tasks over the internet (including many other tasks besides surveys) for a wide range of requesters. Respondents were paid between $\$ 2.00$ and $\$ 5.00$ provided that they submitted valid responses.

${ }^{116}$ Soon after the data collection began, in order to promote participation, volunteer participants were told that every tenth participant would win $\$ 20$. (The promised payments were in fact made).

${ }^{117}$ Craigslist is a free, online classified advertising site. It offers community-specific advertising in New Jersey for North Jersey, Central Jersey, South Jersey, the Jersey Shore, the Philadelphia metropolitan area, and the New York City metropolitan area.

${ }^{118}$ We did not have any respondents from Cumberland County.
} 
and $28 \%$ of respondents came from counties in Southern New Jersey. ${ }^{119}$ The subject pool also had some racial diversity, with $7 \%$ of respondents identifying as African American, $6 \%$ Asian, $4 \%$ Hispanic, less than 1\% identifying as either Native American or Pacific Islander, $74 \%$ White, and $2 \%$ choosing "other." $6 \%$ declined to identify their race. ${ }^{120}$

Regarding marital status, $34 \%$ of the subjects were married, $8 \%$ were divorced or separated, $56 \%$ were single, and 3\% were widowed. ${ }^{121}$ Regarding income, $10 \%$ of our respondents reported a household income below $\$ 20,000,16 \%$ reported from $\$ 20,000$ and $\$ 39,999,22 \%$ reported from $\$ 40,000$ and $\$ 59,999,12 \%$ reported from $\$ 60,000$ and $\$ 79,999,9 \%$ reported from $\$ 80,000$ and $\$ 99,999$, and $20 \%$ reported at or above $\$ 100,000$, with an additional $10 \%$ choosing not to answer. The respondents were also asked to report which political ideology they most closely identified with. The selfreported affiliations were $11 \%$ very liberal, $27 \%$ somewhat liberal, $42 \%$ moderate, $16 \%$ somewhat conservative, and $4 \%$ very conservative.

\section{B. Methodology}

Subjects were given a table of what might be called "milestone" offenses taken from the existing New Jersey Code. The table, reproduced below, presented examples of the kinds of common offenses found in each of the various grading categories used in current New Jersey law. The table included basic offenses against the person (homicide, rape, robbery, assault, endangerment, harassment), offenses against property (theft, burglary), and offenses against public order (disorderly conduct, criminal mischief), thereby ranging across the entire continuum of offense seriousness, from imprisonment for a maximum of 30 days to punishment for life imprisonment without the possibility of parole. The offenses were presented in order of seriousness, and given a numeric level, 1 through 7 , representing each of the grades provided for in the criminal code. ${ }^{122}$

\footnotetext{
119 The following definitions were used: Northern New Jersey is composed of Bergen, Essex, Hudson, Morris, Passaic, Sussex, Union, and Warren Counties. Central New Jersey is composed of Somerset, Middlesex, Monmouth, Mercer, Hunterdon, and Ocean Counties. Southern New Jersey is composed of Burlington, Camden, Gloucester, Salem, Cumberland, Cape May, and Atlantic Counties.

${ }^{120}$ For current New Jersey demographic statistics, see New Jersey Fact Sheet (2005-2009), available at: http://factfinder.census.gov/servlet/ACSSAFFFacts?_event=Search\&_state=04000US34\&_lang=en\&_sse= on.

${ }^{121}$ The percentages reported in this section are rounded to the nearest percentile, which is why the percentages provided for marital status do not add up to exactly $100 \%$.

${ }^{122}$ The levels 1-7 were actually coded 2-8 in the results, with 1 corresponding to the response of "No criminal punishment" and 9 corresponding to "Did not understand the test offense." The "Did not understand the test offense" responses for a particular question were excluded from that question's average grading calculations.
} 
Table A. Milestone Offenses from the New Jersey Criminal Code

\begin{tabular}{|l|l|}
\hline Level 7 & Aggravated Murder: Intentionally killing a 10 year old child. \\
\hline Level 6 & Murder: Intentionally killing an adult. \\
\hline Level 5 & $\begin{array}{l}\text { Aggravated Assault: Serious Bodily Injury: Beating a person to intentionally cause paralysis. } \\
\text { Manslaughter: An owner of dangerous pit bulls causing the death of a neighbor's child by } \\
\text { refusing to fix the broken lock on their cage. } \\
\text { Aggravated Theft: Stealing \$5 million. } \\
\text { Sexual Assault: Forcibly raping an adult. }\end{array}$ \\
\hline Level 4 & $\begin{array}{l}\text { Theft: \$25,000: Stealing \$25,000. } \\
\text { Criminal Mischief: \$25,000: Intentionally causing \$25,000 of property damage. } \\
\text { Aggravated Assault: Bodily Injury: Intentionally slashing another person's shoulder with a knife. }\end{array}$ \\
\hline Level 3 & $\begin{array}{l}\text { Stalking: Intentionally causing another person emotional distress. } \\
\text { Criminal Mischief: \$500: Causing \$500 in property damage. } \\
\text { Theft: \$500: Stealing \$500. }\end{array}$ \\
\hline Level 2 & $\begin{array}{l}\text { Simple Assault: Intentionally giving another person a black eye. } \\
\text { Lewdness: Running naked in a public place. } \\
\text { Petty Theft: \$40: Stealing \$40. } \\
\text { Criminal Mischief: \$40: Causing \$40 in property damage. }\end{array}$ \\
\hline Level 1 & $\begin{array}{l}\text { Harassment: Intentionally annoying a person by making anonymous phone calls to them at } 2 \text { am. } \\
\text { Petty assault: Fighting with another by mutual consent. }\end{array}$ \\
\hline
\end{tabular}

Subjects were then given a series of test offenses, also drawn from current law, and were asked to compare the seriousness of each offense with the milestone offenses presented in the table. Subjects were also given the option of selecting "No criminal punishment." Because the subjects were not likely to be lawyers, to have familiarity with New Jersey Code, or to understand legal language generally, the abstract terms of an offense were translated into concrete facts that would allow the subjects to understand the offense conduct. ${ }^{123}$ In case these translations remained unclear, respondents were able to note that they did not understand the test offense and thus refrain from selecting any seriousness level.

Providing concrete examples of an offense also was also necessary to ensure that different subjects created the same "mental picture" of each offense. Studies on similar research methodologies suggest that subjects perform their comparative judgments by creating in their minds a short imagination of the offense. To the extent that the offense description provided to them is too limited or too abstract, different subjects may fill in different facts to complete their "story," and these different additions by different subjects understandably can produce different judgments about offense seriousness. Different subjects, in essence, can end up comparing different stories. Our methodology

\footnotetext{
${ }^{123}$ Where this was done, the illustrative facts sought to present a common instance of the offense, rather than an unusually severe or unusually trivial instance. However, the chosen situations did not always illustrate the most common instance of the offense. Deviating from the most common instance of the offense was necessary at times, especially when testing offenses that we believed New Jersey residents might find overly broad (those listed in Appendix C). In testing these offenses, two examples of conduct were given that could be prosecuted under the offense. For each offense tested, one example showed conduct exhibiting the least amount of blameworthiness or resulting harm that could be reasonably prosecuted under the offense, and the other showed conduct exhibiting the most amount of blameworthiness or resulting harm that could reasonably be prosecuted under the offense. Even in coming up with these examples, which were intended to flesh out overly broad offenses, efforts were made to stay within the boundaries of what was believed to be the possible applications of the offense.
} 
attempted to minimize the problem by providing sufficient details about each offense. In each instance, the details were written in a way that conformed to the requirements of the New Jersey Code provision governing the offense.

Each subject was asked to categorize 121 scenarios, and asked to answer 9 demographic questions. Of the 121 scenarios, 119 presented offenses in New Jersey Law that we sought to test. ${ }^{124}$ These results are reported in Part I and in the Appendices. The other two scenarios each presented a case that closely mimicked one of the offenses in the milestone table, and were used as a quality control measure to ensure that the respondents were diligently evaluating each test offense. ${ }^{125}$ The online survey collected 222 responses for each test scenario, upon which to base the residents' grading judgments reported in Part I and the Appendices. ${ }^{126}$ Reported judgments are based upon the mean of the subjects' grading, with the raw numerical score, the median, and the standard deviation reported in the notes. ${ }^{127}$ The full results of the study, including statistical significance tests for all results, are reported in Appendix F. ${ }^{128}$

${ }^{124}$ Of the 119 scenarios that were designed to test the offenses from the New Jersey laws, 97 were representative of a single offense, while 22 of the scenarios were representative of high and low ends of 11 offenses that we suspected were too broad (see supra, Part I.D). This construction allowed us to test a total of 108 offenses through this survey.

${ }^{125}$ Of the 222 respondents, 180 respondents correctly answered two control questions (described in Appendix G) presented in the survey. The remaining respondents missed one of the control questions by no more than one degree and answered the other control question correctly. To ensure that including the latter group of respondents did not reduce the accuracy of the results, the survey results (fully presented in Appendix F) were also calculated for only those respondents who answered both of the control questions correctly. For the most part, there was little difference in the responses. For none of the questions in the survey was the difference in the mean response between the two groups (one including all responses, and the other including only the 180 responses where both control questions were answered correctly) greater than 0.17 grades. The median responses for all questions were the same between the two groups except for five questions, where the difference in medians for three questions was 0.5 , and the difference in medians for two questions was 1. Limitation of responses to the smaller response pool affected the statistical significance at the 0.5 level of the difference between the survey median and the legislative grade for only one question, X4_423.

${ }^{126}$ For all but one question, we received anywhere from 202 to 222 valid responses, as we excluded the "I do not understand the test offense" responses from this statistical analysis.

${ }^{127}$ The conversion of average scores to criminal grades followed the table below:

\begin{tabular}{|l|l|l|}
\hline $\begin{array}{l}\text { Value on } \\
\text { Milestone } \\
\text { Table }\end{array}$ & $\begin{array}{l}\text { Mean Values in this Range were Treated as } \\
\ldots\end{array}$ & $\begin{array}{l}\text {. Indicating Subject Preference for } \\
\text { this Offense Grade... }\end{array}$ \\
\hline 7 & $7.50-8.00$ & Aggravated Murder \\
\hline 6 & $6.50-7.49$ & First Degree Crime \\
\hline 5 & $5.50-6.49$ & Second Degree Crime \\
\hline 4 & $4.50-5.49$ & Third Degree Crime \\
\hline 3 & $3.50-4.49$ & Fourth Degree Crime \\
\hline 2 & $2.50-3.49$ & Disorderly Persons Offense \\
\hline 1 & $1.50-2.49$ & Petty Disorderly Persons Offense \\
\hline N/A & $1.00-1.49$ & No Punishment \\
\hline
\end{tabular}

This table is based upon the numeric levels used in Table A, reproduced in Part II above, and the corresponding grades found in N.J. Stat. Ann. §2C: 43-8 (West 2010) and N.J. Stat. Ann. §2C: 43-6 (West 2010). This table reflects normal rounding conventions applied to the mean scores.

${ }^{128}$ Statistical significance was calculated using a modified version of the Sign Test. The Sign Test was chosen over the more familiar t-test because the data probably do not satisfy the normality assumption of the t-test, and the data are measured only on an ordinal scale. The form of the Sign Test that was used is 


\section{Why Should We Care About Getting Offense Grades Right?}

Part I suggests that there are serious problems in the way New Jersey law currently grades criminal offenses. Should we care? Why is proper offense grading important?

\section{A. Offense Grades that Conflict with Community Views Undermine the Criminal Law's Moral Credibility and, Thereby, Its Ability to Fight Crime}

If one cares about achieving justice, as all societies aspire to do, caring about imposing the proper level of punishment for crimes, neither too much nor too little, is a necessity. Doing justice has deontological value of its own and requires no further justification. It is the mark of a civilized society.

However, recent social science research suggests that a criminal justice system's reputation for doing justice has more than just deontological value. It also has important practical value in fighting crime. If the system's liability and punishment rules track the community's shared understandings of justice, the resulting moral credibility of the system promotes cooperation, acquiescence, the powerful social influences of stigmatization and condemnation, and increases criminal law's ability to shape societal and internalized norms. In contrast, where the law's offense grading judgments conflict with the community's lay intuitions of justice, it undermines these benefits. A criminal justice system seen as unjust promotes resistance and subversion, loses the power of stigmatization and condemnation, and undermines the law's ability to shape the powerful forces of social norms. ${ }^{129}$

\section{B. Offense Grades Tell Citizens the Relative Importance of Conflicting Duties}

Proper grading of offenses is also essential because it signals the Legislature's judgments as to the relative seriousness of different offenses. ${ }^{130}$ Those judgments are vital information for a variety of reasons. First, offense grades tell citizens how careful they must be to avoid one offense over another. Speeding is less serious than vehicular homicide; thus it follows that a citizen ought to pay relatively more attention to avoiding

more conservative than the standard sign test or the t-test (i.e., it will tend to understate the significance of an observation), giving us confidence that those observations denoted significant actually are significant. Note that the Sign Test actually measures the difference between the median of the survey responses (not the mean) and the legislative grade. The method used was described by John D. Emerson and Gary A.

Simon. See John D. Emerson and Gary A. Simon, Another Look at the Sign Test When Ties Are Present: The Problem of Confidence Intervals, 33 THE AMERICAN STATISTICIAN 140, 140-42 (1979).

${ }^{129}$ For a discussion of the literature, see PAUL H. ROBINSON, DisTRIBUTIVE PRINCIPLES OF CRIMINAL LAW: Who Should Be Punished How Much? $135-212$ (2008); Paul H. Robinson and John Darley, Intuitions of Justice: Implications for Criminal Law and Justice Policy, 81 S. CAL L. REV. 1 (2007); Paul H.

Robinson, Geoffrey P. Goodwin, and Michael Reisig, The Disutility of Injustice, NEW YORK UNIV. L. REV (forthcoming 2011), available at http://ssrn.com/abstract=1470905.

${ }^{130}$ N.J. Stat. Ann $\$ 2 \mathrm{C}: 1-2 . \mathrm{a}(5)$ (West 2010) ("The general purposes of the provisions governing the definition of offenses are:... To differentiate on reasonable grounds between serious and minor offenses"). 
the latter than the former. ${ }^{131}$ And when a citizen's different duties conflict, the relative grades of the two relevant offenses tell the person which duty must take priority over another. ${ }^{132}$ It is the Legislature's assessment of the relative seriousness of the offenses as reflected in its relative grading of the relevant offenses - that should be given deference, not each individual's personal judgment of the matter. For example, animals are entitled to a life free from cruelty, and cruelty to animals is therefore criminalized. ${ }^{133}$ Should a person feel entitled to use force to take pets from a cruel owner if doing so seems necessary to protect his animals from imminent harm? New Jersey law grades robbery with any amount of force (however slight) as a crime of the 2 nd degree and grades cruelty to animals as only a disorderly persons offense. ${ }^{134}$ This relative grading of the two harms signals to citizens they may not use force in such a situation, despite any personal moral judgment to the contrary.

\section{Offense Grades Express the Legislature's Values, Avoiding Ad Hoc Delegation of Such Value Judgments to Individual Judges}

Even more important, however, is the role that offense grading plays in ensuring that the relative seriousness of offenses is defined according to the Legislature's judgment, rather than delegating this significant authority to the discretion of individual sentencing judges ad hoc. Assessments of proper offense grade are classic expressions of societal values, which are properly set by the most democratic branch of government and the one charged with collectively making such value judgments - the Legislature. Such value judgments ought never be left to the ad hoc discretion of any individual, even one as well regarded as a judge. ${ }^{135}$ The grade given to an offense sets the maximum sentence to be imposed for the offense, providing a hard limit to sentencing discretion. Admittedly, judicial discretion is needed to properly weigh the myriad complex mitigations and excuses that might reduce an offender's deserved punishment below that statutory maximum, but judges ought to remain bound by the maximum limit on punishment that flows from the Legislature's grading judgment.

\section{Offense Grades Ensure a Fixed Rule for All Offenders}

The judgment of the Legislature is preferred to that of the Judiciary not only because it is the more democratic branch, but also because it is the only branch whose rules can be applied equally to all offenders. The exercise of individual judicial discretion is necessarily ad hoc; reliance upon judicial value judgments inevitably invites differing judgments for different offenders. However, a central part of doing justice is

\footnotetext{
${ }^{131}$ N.J. Stat. Ann. §2C:11-5 (West 2010) (Death by vehicular homicide): “Criminal homicide constitutes vehicular homicide when it is caused by driving a vehicle or vessel recklessly." Vehicular homicide is a crime of the second degree. Id.

132 See N.J. Stat. Ann §2C:3-1 (West 2010) (Justification as an affirmative defense); N.J. Stat. Ann. §2C:32 (West 2010) (Necessity and other justifications in general). See also N.J. Stat. Ann. §2C:1-2a (West 2010) (Purposes, principles of construction).

${ }^{133}$ N.J. Stat. Ann. $\$ 4:$ 22-17 (West 2010) (Prevention of Cruelty to Animals).

${ }^{134}$ Compare N.J. Stat. Ann. §2C:15-1 (West 2010) (Robbery), with N.J. Stat. Ann. §4:22-17 (Prevention of Cruelty to Animals) (West 2010).

${ }^{135}$ See N.J Stat. Ann. §2C:1-2b(1) (West 2010); N.J. Stat. Ann. §2C:1-2b(4) (West 2010).
} 
treating similarly-situated offenders in similar ways. An offender's punishment ought to depend upon what he has done and his culpability and capacities at the time of doing it. It ought not depend upon who happens to be assigned as a sentencing judge and his or her personal value judgments. Yet, when an offense grade is set so high as to provide no practical limit on judges' discretion, it has the effect of leaving the judgment of relative seriousness of the offense to individual judges. Improperly high offense grades effectively allow each sentencing judge to decide for himself or herself the relative seriousness of the offense at hand, based upon personal values which may not coincide with the Legislature's.

\section{E. Improper Offense Grades May be Costly and Inefficient}

In addition to encouraging injustice and creating crime-control problems, improper grading of offenses can lead to inefficient spending. A rational punishment system allocates its expenditures to punish more serious offenses more than less serious offenses. Prison is expensive. ${ }^{136}$ In a world of finite resources, funds spent on less serious offenses are not available to punish more serious offenses. For the Legislature to exercise control over prison spending and to ensure the most efficient use of its punishment expenditures, the law must properly identify through its grading the true relative seriousness of different offenses.

\section{How Did These Grading Problems Come About?}

New Jersey departed from common law criminal sentencing with the Code of Criminal Justice which became effective in 1979. Title 2C established the comprehensive grading of 243 critical offenses and suboffenses. Since then there has been an enormous number of offense-related legislative amendments in New Jersey: 863 - an average of nearly 29 amendments every year for 30 years! (And the rate of amendments is increasing! See Appendix E.) The large number of amendments has seriously degraded the original Criminal Code and produced an increasingly convoluted body of law riddled with grading irrationalities and internal inconsistencies illustrated by the examples presented in Part I. ${ }^{137}$

The grading problems result largely from the ad hoc nature of New Jersey's criminal law legislation, with significant exacerbation by the natural political dynamics of crime legislation - including what has been called the "crime du jour" problem. These forces are not unique to New Jersey, but rather are typical of most (if not all) American jurisdictions.

When a criminal code is first created, a natural part of the codification process is to sort all offenses and suboffenses into one of the offense grading categories according to the relative degree of seriousness of each offense as compared to other offenses. This is, of course, one of the central purposes of having a criminal code: to set legislative choices regarding the relative seriousness of offense conduct rather than to leave such

\footnotetext{
${ }^{136}$ The average cost of incarceration in 2008 was $\$ 1.58$ billion, or 4.8 percent of New Jersey's total spending that year. 1 in 31: The Long Reach of American Corrections - New Jersey (Pew Center on the States 2009), available at http://www.pewcenteronthestates.org/report_detail.aspx?id=49382.

137 See Appendix E.
} 
value judgments to the ad hoc discretion of individual sentencing judges. ${ }^{138}$ When crime legislation is taken up in piecemeal fashion, however, it is common for the focus to be only on the contours and scope of the conduct at hand. This more narrow focus neglects consideration of how the new offense or grade relates to the other offenses in existing law, and leads to the types of grading irrationalities described in Part I above.

The narrow focus is particularly common when legislative activity responds to a problem of the day that has caught the attention of the news media or is pressed by a particular interest group. It is natural in such cases for legislators to think that some response is needed. Unfortunately, the only response typically available to them is to pass legislation, even though the provoking event often has nothing to do with some weakness in the criminal law and cannot be avoided in the future by anything that the legislators can do to the law. Sometimes, it is simply the case that bad people do bad things and, sadly, other bad people may do similar bad things in the future. If there is anything to be done to reduce the likelihood of such a crime in the future, commonly it is a reform needed in some other branch of government, such as a change in the allocation of police resources (or in changes in other aspects of society, unrelated to criminal justice).

Nonetheless, when faced with events upsetting to constituents, legislators commonly feel a need to do something - if only to show constituents that they are responsive to the situations about which there is concern. Such legislative responsiveness is a quality that citizens understandably prize, and it is no surprise that legislators react as they do. Unfortunately, amendments and additions to the criminal law are often unhelpful and, worse, may hurt the cause of fighting crime and doing justice. In many instances, the criminal justice system would be better off without new legislation or, at the very least, with legislation better attuned to the larger need for a rational and coherent criminal code. More often than not, such "crime du jour" legislation actually ends up undermining the criminal code rather than improving it.

For example, in 2002 a new subsection 5 was added to New Jersey's "Interference with Transportation" prohibitions proscribed by $\S 2 \mathrm{C}: 33-14(\mathrm{a}) .{ }^{139}$ The new subsection specifically criminalized the unlawful disruption of, among other modes of transportation, "any ... airplane or any ... facility of transportation." Any conviction under this section is a disorderly persons offense, punishable by a term of up to 6 months in prison if the offender causes a pecuniary loss up to $\$ 500$ but with no risk of bodily injury to another person. But the new legislation was hardly necessary: such conduct was already prohibited under $\S 2 \mathrm{C}: 17-3(\mathrm{~b})(5)$ as "Criminal Mischief," which criminalizes the unlawful interference or tampering with any "airport, landing field, landing strip ... or any other aviation facility." "That statute was enacted in 1998 and grades such conduct as a crime of the 4th degree, punishable by imprisonment for up to 18 months. The unnecessary addition simply created conflict and confusion that did not previously exist.

Another example concerns "Carjacking," an offense codified in 1993 at $\$ 2 \mathrm{C}: 15-$ 2. The new statute criminalized carjacking: "inflict[ing] bodily injury or us[ing] force upon an occupant or person in possession or control of a motor vehicle" while

\footnotetext{
${ }^{138}$ N.J. Stat. Ann. §2C:35-1.1a (West 2010).

${ }^{139}$ N.J. Stat. Ann. §2C:33-14a(5) (West 2010).

${ }^{140}$ N.J. Stat. Ann. $\$ 2 C: 17-3 b(5)$ (West 2010).
} 
"committing an unlawful taking of a motor vehicle." 141 Any conviction under this section is a crime of the 1st degree and is punishable by a range of imprisonment from ten to thirty years. ${ }^{142}$ The new offense, however, was already covered by $\$ 2 C: 15-1$, "Robbery with a Threat of Bodily Injury." That statute was part of the original code which became effective in 1979, amended in 1981, criminalizing the conduct of "inflict[ing] bodily injury or us[ing] force upon another" as part of the commission of a theft. ${ }^{143}$ Under this statute, the conduct (without further aggravating factors) is graded as a crime of the 2 nd degree. It is once again unclear why Title $2 \mathrm{C}$ should need two separate offenses criminalizing the same conduct but with different grades.

Beyond the problem of unnecessary offenses that commonly overlap and have inconsistent offense grades with existing offenses, the ad hoc "crime du jour" dynamic tends to distort the grading judgment of the relative seriousness of the new offense as compared to other offenses. When people are worked up about the offense conduct at hand, it is natural for that concern to temporarily exaggerate the relative seriousness of that conduct as against other conduct not now in the limelight. However, when the heat dissipates and attention moves on to the next "crime du jour," the law is left with a distortion in its grading scheme. These distortions accumulate over time, making it increasingly difficult to get the relative grading right. Should the latest new offense be graded according to the older standard of relative seriousness that existed before the latest distortion, or graded according to the new standard set by the most recent exaggerated grading?

The extent of the problem is bad and becoming worse. Since the Code of Criminal Justice became effective in 1979, we have seen 597 amendments to Title 2C and another 266 crimes-related amendments to non-2C titles. This represents an average of roughly 20 new amendments per year within Title $2 \mathrm{C}$, and almost another 9 amendments scattered annually among other titles of the New Jersey law. More troubling is the fact that rate of criminal-law related amendments is increasing both within the entire body of New Jersey law and specifically within Title 2C. ${ }^{144}$ This suggests that the problems resulting from ad hoc crime legislation are likely to get increasingly worse. How can those problems be fixed, and how can they be avoided in the future?

${ }^{141}$ N.J. Stat. Ann $\S 2$ C:15-2 (West 2010) (Carjacking): “A person is guilty of carjacking if in the course of committing an unlawful taking of a motor vehicle...or in an attempt to commit an unlawful taking of a motor vehicle he: (1) inflicts bodily injury or uses force upon an occupant or person in possession or control of a motor vehicle; (2) threatens an occupant or person in control with, or purposely or knowingly puts an occupant or person in control of the motor vehicle in fear of, immediate bodily injury; (3) commits or threatens immediately to commit any crime of the first or second degree; or (4) operates or causes said vehicle to be operated with the person who was in possession or control or was an occupant of the motor vehicle at the time of the taking remaining in the vehicle. . . Carjacking is a crime of the first degree."

${ }^{142} I d$.

${ }^{143}$ N.J. Stat. Ann $§ 2$ C:15-1 (West 2010) (Robbery with Death or Serious Bodily injury): “A person is guilty of robbery if, in the course of committing a theft, he: (1) Inflicts bodily injury or uses force upon another; or (2) Threatens another with or purposely puts him in fear of immediate bodily injury; or (3) Commits or threatens immediately to commit any crime of the first or second degree. . . It is a crime of the first degree if in the course of committing the theft the actor attempts to kill anyone, or purposely inflicts or attempts to inflict serious bodily injury, or is armed with, or uses or threatens the immediate use of a deadly weapon."

${ }^{144}$ See Tables $1 \& 2$, Appendix E, infra at 43. 


\section{How Can These Problems Be Fixed?}

Ideally, the best way to deal with the problems described in Part I would be to recodify the state's criminal law into a code that drops unnecessary and duplicative offenses and that resets the grades of all offenses in a way that reflects each offense's relative seriousness in relation to all others. Additionally, such a recodification effort could address the problem of having hundreds of criminal offenses codified outside of the state's criminal code. Past recodification efforts suggest that the 1554 offenses and suboffenses contained in current law could be consolidated into a crimes code of equal coverage but with greater clarity and simplicity, and with far fewer offenses, much like the original code which became effective in 1979 did using just 243 offenses and suboffenses. ${ }^{145}$ The recodification could be done without any purpose to change the legislative judgments embodied in existing law, but rather to simply recast those judgments into a rational, coherent code. Existing law would need to be changed only to the extent that it is internally inconsistent, requiring the recodifiers to choose between two conflicting positions - preferably selecting the one that best captures present legislative values.

It may be, however, that such a recodification project is not currently politically feasible. ${ }^{146}$ On the other hand, the political appeal of such recodification is likely to increase with time, as the acceleration of ad hoc criminal law amendments has the cumulative effect of increasing the law's complexity, duplicity, and irrationality. A more modest approach would be to simply fix the kinds of irrationalities and inconsistencies illustrated in this Report and its Appendices.

To do this, the Legislature would need to re-examine the offense grading judgments contained in existing law. Such an examination could be informed by the judgments of New Jersey residents on the relative seriousness of different offense conduct, as revealed in a study such as that described in Part II of this Report.

Specifically, the grading reform program could:

- Reconsider the grade of each offense in relation to other offenses. This reevaluation certainly should include all of the examples of improper grading set out in Appendix A, but ideally would consider all offenses and suboffenses in

\footnotetext{
${ }^{145}$ In 2003, Kentucky sought to revise its penal code, which had increased by hundreds of offenses since the state had adopted a new code in 1974. The Kentucky Penal Code Revision Project was able to consolidate the offenses into a clear, comprehensible, and rational statement of Kentucky criminal law that retained policy decisions of the current code, but reduced its size to close to 1974 levels. The Kentucky Penal Code Revision Project's Report is available at: http://www.law.upenn.edu/fac/phrobins/kentucky/KYFinalReportVol1.pdf (volume 1); http://www.law.upenn.edu/fac/phrobins/kentucky/KYFinalReportVol2.pdf (volume 2). Illinois undertook a similar recodification effort and found that many sections of the new code were able to state Illinois law in less than $10 \%$ of the words than were used in the then-current code! In 2003, Illinois published a report entitled, The Illinois Criminal Code Rewrite and Reform Commission's Report, which is available at: http://www.law.upenn.edu/fac/phrobins/illinois/IL\%20final\%20report\%20Vol1.pdf (volume 1); http://www.law.upenn.edu/fac/phrobins/illinois/IL\%20final\%20report\%20Vol2.pdf (volume 2).

${ }^{146}$ For a detailed discussion of political obstacles facing penal code reform and ways to overcome them, see Paul H. Robinson \& Michael T. Cahill, The Accelerating Degradation of American Criminal Codes, 56 HASTings L.J. 633, 645-52 (2005) .
} 
current law, both within and outside of Title $2 \mathrm{C}$. A carefully constructed survey of New Jersey residents could be useful in assessing the proper grade of an offense as compared to other offenses. ${ }^{147}$

- Review all mandatory minimums prescribed by New Jersey law, especially those referred to in Appendix B, to ensure that each is really needed and appropriate. The project should ask in each instance:

1. What indications suggest that judges are so likely to abuse their sentencing discretion (and to go outside of the sentencing guidelines) that a mandatory minimum sentence is necessary? Abolishing mandatory minimums, and simultaneously enacting stronger sentencing guidelines, might be a better way for the Legislature to control sentencing discretion. ${ }^{148}$

2. If a mandatory minimum is thought to be necessary, at what level should it be set? One would want to avoid setting it so high as to require sentences in excess of the relative seriousness of the offense as compared to other offenses. Avoiding this problem requires considering not only the seriousness of the paradigm case of the offense, but also the mitigated instances of the offense that might arise. Caring about justice being done requires not only ensuring that offenders get the punishment they deserve but also that they get no more punishment than they deserve. A survey of New Jersey residents could help resolve these issues.

- Abolish overlapping offenses where possible. Some of the most egregious examples of this overlap - for example, in which specific and general offenses of the same seriousness are graded differently - are illustrated in Parts I.C and I.F above. Overlapping offenses should be evaluated with the goal of determining whether there is a logical reason for the current grading differences. Ideally, all duplicative offenses should be abolished as unnecessary if the conduct is already covered, as by a general offense, and no special grading difference is justified. Refinements of general offenses could be made, if needed, to make clear that some specific conduct is indeed included in the general offense. ${ }^{149}$

- Review current crime definitions to ensure that only conduct of the same degree of seriousness is included within the same grade of the offense or suboffense. Where an offense includes conduct of importantly different degrees of seriousness, such as those offenses listed in Appendix C, the offense should define suboffenses for different grades. Here too, a survey of New Jersey

\footnotetext{
${ }^{147}$ For an extended discussion of the benefit of incorporating lay opinions in criminal laws, see Paul $\mathrm{H}$. Robinson and John Darley, Intuitions of Justice: Implications for Criminal Law and Justice Policy, $81 \mathrm{~S}$. CAL L. REV. 1 (2007); Paul H. Robinson, Geoffrey P. Goodwin, and Michael Reisig, The Disutility of Injustice, NEW YORK UNIV. L. REV (forthcoming 2011), available at http://ssrn.com/abstract=1470905. ${ }^{148}$ See, e.g., Paul G. Cassell, Too Severe?: A Defense of the Federal Sentencing Guidelines (and A Critique of Federal Mandatory Minimums), 56 STAN. L. REV. 1017, 1044-48 (2004) (arguing that the establishment of strong sentencing guidelines eliminates the need for mandatory minimum sentences). ${ }^{149}$ See Parts I.C and 1.F, supra at 6-7 and 12-13.
} 
residents could help resolve whether different courses of conduct contained within a single offense require creation of separate suboffenses with different offense grades.

- Integrate into Title $2 \mathrm{C}$ all serious offenses and sentence enhancements now contained outside of Title 2C. This is important to give fair notice of the conduct that is criminal. How can residents know what is criminal if the definitions of crimes are scattered through many titles of current law? It is also necessary to increase the likelihood that future efforts to amend current law will be made with a full awareness of what current law already provides, a task that becomes quite difficult even for the most diligent legislator if the offenses are scattered across many titles. ${ }^{150}$

\section{- Repeal offenses that punish conduct that New Jersey residents find} insufficiently blameworthy to deserve the condemnation of criminal conviction. To avoid diluting the condemnation carried by a criminal conviction, liability ought to be limited to the conduct that, in the view of the community as a whole, deserves criminal condemnation. ${ }^{151}$

\section{How Can Such Grading Irrationalities Be Avoided In the Future?}

Even if a recodification or a regrading program successfully produces a more rational set of offense grading distinctions, it is likely that the dynamics that have degraded current New Jersey criminal law would continue to operate and would begin to immediately degrade the code again, just as they did after the original Code became effective in 1979. While the recodification effort would certainly bring an improvement over the present state of the law, it would be useful to consider how the degradation problem might be avoided in the future, eliminating the need for regular recodification projects.

Here are several proposals, including both minimalist and ambitious approaches. They are admittedly not typical legislative procedures (although there is precedent for some of the items), but given crime legislation's unique political dynamics, such unusual approaches may be both appropriate and effective. There are few other sorts of legislation that carry a threat as easy to make and as powerful in effect as the "soft on crime" epithet at the next election. The resulting problem is that good legislators vote for bad bills in record numbers. The following proposals attempt to attack the problem by changing the crime legislation dynamics.

\footnotetext{
${ }^{150}$ This scenario also presents a problem in other states. See Robinson and Cahill, 56 HASTINGS L.J.. at 636 (discussing instances of serious crimes occurring outside the criminal codes in Illinois and Kentucky).

${ }^{151}$ Where surveyed New Jersey residents chose to assign "no criminal punishment," there is an indication that the community may no longer view the conduct which comprises those offenses as deserving of criminal condemnation. See, e.g., N.J. Stat. Ann. §2C:34-2b (West 2010) (Obscenity for persons 18 years of age or older) (Appendix F, item E9), N.J. Stat. Ann. §2C:40A-5 (West 2010) (Additional penalty for attorneys; grade of offense) (Appendix F, item E10). A more complete survey of the offenses within New Jersey's code would need to be done in order to eradicate all such out-dated offenses.
} 
The general approach is to encourage greater public disclosure and debate on crime legislation. By making more public the strengths and weaknesses of a crime bill, the hope is to allow more thoughtful and responsible voting by legislators.

\section{- Require Crime Bills to Contain an "Existing Crimes Comparison}

Statement": Either through the establishment of a legislative practice or the creation of a formal procedural rule, require that:

1. Legislation proposing a new or expanded offense must include a description of the most related offenses in existing law and a showing that those offenses do not already criminalize the conduct sought to be criminalized in the proposed offense.

2. Legislation proposing either a new or expanded offense or a change in the grading of an existing offense, must include a description of the grades of the existing offenses most similar in seriousness to the proposed offense, and an analysis of how the proposed grading should be similar or different from the related existing grading.

3. Any addition or amendment to an offense must be made within Title $2 \mathrm{C}-$ that is, no new criminal offenses should be added outside of the Criminal Code.

- Require a Public Critique of Each "Existing Crimes Comparison Statement" by Each Judiciary Committee Before a Vote on Any Crime Bill: One might require that both the Senate and Assembly Judiciary Committees issue a statement in which they critique the Existing Crimes Comparison Statement offered for each crime bill before that bill is put to a vote. This would either deter bill sponsors from making unsustainable claims in support of their bill, or expose the weakness of their claims before a vote, thereby giving legislators public political justification for voting against a bad bill.

- Establish a Standing Criminal Law Revision Commission (That Would, Among Other Things, Issue a Critique Before a Vote on Any Crime Bill): The greatest attraction of a Standing Criminal Law Revision Commission is that it could foster a long-term expertise on the state's criminal law, together with the resources to regularly comment on the crime bills introduced, based on their research assessments of the Code's true needs rather than the political dynamics of "crime du jour." A central theme of this Report has been the need to step back from the heat of "crime du jour" dynamics and to consider the larger picture of the criminal code's needs as well as its internal integrity. A Standing Commission working apart from the Legislature could provide the needed distance and larger perspective to offer and encourage needed reforms while discouraging reforms that degrade the code. ${ }^{152}$

- Create an Official Commentary to the Criminal Code as a Permanent, Updated Document: While the proposals above may serve to discourage

${ }^{152}$ See Robinson \& Cahill, supra note 146. 
unnecessary "crime du jour" bills that only complicate the application of the state's criminal law and produce serious grading irrationalities, they do not solve the problem of legislators who have a need to show their constituents that they are indeed aware of and enthusiastic to respond to a crime problem that constituents are concerned about. If amending the criminal code is not an effective way of solving a perceived crime problem, legislators ought to have some other (less destructive) means by which they can show their concern for crime problems that their constituents see. As a practical matter, the pressure for unhelpful crime bills can be reduced only if some other mechanism is available to legislators to signal their interest in their constituents' concerns about crime.

One means of doing this might be to create an official commentary to the criminal code. Any serious code reform project inevitably produces such a commentary, but the thought here is to give that commentary a continuing permanent official status, such that there is legal significance to amending the commentary in the future. Thus, when a perceived crime problem generates a need for some kind of legislative action, legislators can, rather than pressing a new, unnecessary crime or a distortion in offense grading, direct the creation of an amendment of the official commentary to "clarify" any ambiguity that might exist regarding the application of the existing offense. For example, rather than creating a new, more specific redundant offense covering the "crime du jour," the commentary might be amended instead with language that makes it clear that the existing offense does indeed cover the "crime du jour" conduct of present concern. The official commentary might make it clear, for example, that the conduct of cruelly beating a horse ${ }^{153}$ really is included in and prohibited by the offense of cruelty to animals, ${ }^{154}$ that vandalizing a railroad ${ }^{155}$ really is an instance of the offense of criminal mischief, ${ }^{156}$ and that carjacking ${ }^{157}$ really is an instance existing offense of robbery with a threat of bodily injury. ${ }^{158}$

\footnotetext{
${ }^{153}$ N.J. Stat. Ann. §39:4-23 (West 2010) (Ill-treatment of Horses): “[A] person who unnecessarily or cruelly beats a horse shall be guilty of a crime of the fourth degree..."

${ }^{154}$ N.J. Stat. Ann $\S 4: 22-17$ (West 2010) (Cruelty to Animals): “A person who shall purposely, knowingly, or recklessly...cruelly beat, or needlessly mutilate a living animal or creature... [s]hall be guilty of a crime of the fourth degree."

${ }^{155}$ N.J. Stat. Ann §2C:33-14.1 (West 2010) (Vandalizing Railroad Signals or Protective Devices): “Any person who purposely, knowingly or recklessly defaces, damages, obstructs, removes or otherwise impairs the operation of any. . railroad property or equipment. . for a first offense, be guilty of a crime of the fourth degree" if there is no bodily injury or death, and the loss caused is less than $\$ 2000.00$.

${ }^{156}$ N.J. Stat. Ann $§ 2 \mathrm{C}: 17-3$ (West 2010) (Criminal Mischief): “ Purposely, knowingly or recklessly tampers with tangible property of another so as to endanger person or property.... is a crime of the fourth degree if the actor causes pecuniary loss in excess of $\$ 500.00$ but less than $\$ 2000.00$."

${ }^{157}$ N.J. Stat. Ann $\$ 2$ C:15-2 (West, adopted in 1993) (Carjacking): “A person is guilty of carjacking if in the course of committing an unlawful taking of a motor vehicle... or in an attempt to commit an unlawful taking of a motor vehicle he: (1) inflicts bodily injury or uses force upon an occupant or person in possession or control of a motor vehicle; (2) threatens an occupant or person in control with, or purposely or knowingly puts an occupant or person in control of the motor vehicle in fear of, immediate bodily injury; (3) commits or threatens immediately to commit any crime of the first or second degree; or (4) operates or causes said vehicle to be operated with the person who was in possession or control or was an occupant of the motor vehicle at the time of the taking remaining in the vehicle. . . Carjacking is a crime of the first degree."
} 
The official commentary and its amendments would not have illusory power. They would indeed serve as a standing statement of legislative intent on the meaning of the offense that the courts would be obliged to take into account in their interpretation of any ambiguities in the language of the offense definition. ${ }^{159}$

Ultimately, rational offense grading will depend upon the extent to which the legislators, and in particular their leaders, are willing to commit themselves to doing justice - giving offenders the punishment they deserve, no more and no less.

${ }^{158}$ N.J. Stat. Ann $\S 2$ C:15-1 (West 2005) (Robbery with Death or Serious Bodily injury): “A person is guilty of robbery if, in the course of committing a theft, he: (1) Inflicts bodily injury or uses force upon another; or (2) Threatens another with or purposely puts him in fear of immediate bodily injury; or (3) Commits or threatens immediately to commit any crime of the first or second degree. . . It is a crime of the first degree if in the course of committing the theft the actor attempts to kill anyone, or purposely inflicts or attempts to inflict serious bodily injury, or is armed with, or uses or threatens the immediate use of a deadly weapon." Two decades after passage of the criminal code, the legislature enacted a new statute providing that carjacking shall be graded as a first degree felony. This specific statute addressed conduct already barred under the generic robbery statute, and graded the two offenses inconsistently. Compare N.J. Stat. Ann $\S 2 \mathrm{C}: 15-1$ (West 2010) (grading robbery with death or serious bodily injury as a first degree crime and all other robbery as a second degree crime), with N.J. Stat. Ann §2C:15-2 (West 2010) (grading carjacking as a first degree offense, with a mandatory minimum of five years imprisonment). This grading is problematic for two reasons: first, the two offenses create a grading discrepancy, and, second, the specific offense allows for less nuance in grading and punishment. While the generic robbery statute makes grading distinctions based upon the severity of the injuries occurring during a robbery, the specific statute does not. An offender stealing a car who kills the car's driver is punished the same as one who does not. Conversely, an offender stealing a car who does not kill the driver faces the same mandatory minimum sentence as an offender who does.

${ }^{159}$ For further discussion of the use of an official commentary, see Paul H. Robinson and Michael T. Cahill, The Accelerating Degradation of American Criminal Codes, 56 Hastings L. J. 633, 654-55 (2005). 


\title{
VII. APPENDiCES
}

\section{Appendix A: More Examples of the Improper Grade Problem}

\author{
Offenses Graded by New Jersey Residents Lower Than Current Law:
}

- Recklessly keeping flammable liquid in a kitchen next to a gas stove that could cause widespread damage to the surrounding area if it caught fire and continuing to use the stove in spite of the risk ${ }^{160}$ is graded by the New Jersey residents as similar in seriousness to intentionally giving another person a black eye, a disorderly persons offense, which has a maximum penalty of 6 months imprisonment, ${ }^{161}$ but under current law the offense is graded as a $3 \mathrm{rd}$ crime, which has a maximum sentence of 5 years imprisonment. ${ }^{162}$

- A pawnbroker who knowingly offers to sell a pistol to a man who comes into his store $^{163}$ is graded by New Jersey residents as similar in seriousness to intentionally giving another person a black eye, a disorderly persons offense, which has a maximum sentence of 6 months imprisonment, ${ }^{164}$ but under current law the offense is graded as a 3rd degree crime, which has a maximum sentence of 5 years imprisonment. ${ }^{165}$

- Knowingly conducting a marijuana growing operation with 30 marijuana plants ${ }^{166}$ is graded by the New Jersey residents as similar in seriousness to intentionally causing another emotional distress, a 4th degree crime, which has a maximum sentence of 18 months imprisonment, ${ }^{167}$ but under current law the offense is graded as a 2 nd degree crime, which has a maximum sentence of 10 years imprisonment. $^{168}$

- Possessing half a gram of cocaine, which has a street value of about $\$ 35^{169}$ is graded by New Jersey residents as similar in seriousness to intentionally giving another person a black eye, a disorderly persons offense, which has a maximum sentence of 6 months imprisonment, ${ }^{170}$ but under current law the offense is graded as a 3rd degree crime, which has a maximum sentence of 5 years imprisonment. $^{171}$

\footnotetext{
${ }^{160}$ N.J. Stat. Ann. $§ 2 C: 17-2 c$ (West 2010).

${ }^{161}$ Mean $=3.02$, Median $=3, \mathrm{SD}=1.80$ (Appendix F, item A6).

${ }^{162}$ N.J. Stat. Ann. §2C:43-6a(3) (West 2010).

${ }^{163}$ N.J. Stat. Ann. §2C:39-11(a) (West 2010).

${ }^{164}$ Mean $=2.69$, Median $=2, \mathrm{SD}=1.75$ (Appendix F, item A7).

${ }^{165}$ N.J. Stat. Ann. §2C:43-6a(3) (West 2010).

${ }^{166}$ N.J. Stat. Ann. §2C:35-5(b)(10)(b) (West 2010).

${ }^{167}$ Mean $=3.57$, Median $=4, \mathrm{SD}=1.56$ (Appendix F, item A8).

${ }^{168}$ N.J. Stat. Ann. §2C:43-6a(2) (West 2010).

${ }^{169}$ N.J. Stat. Ann. §2C:35-10a(1) (West 2010).

${ }^{170}$ Mean $=2.90$, Median $=3, S D=1.21($ See Appendix F, item A10).

${ }^{171}$ N.J. Stat. Ann. §2C:43-6a(3) (West 2010).
} 
- Threatening to punch someone if he registers to vote in the next election ${ }^{172}$ is graded by New Jersey residents as similar in seriousness to intentionally causing another person emotional distress, a 4th degree crime, which has a maximum sentence of 18 months imprisonment, ${ }^{173}$ but under current law the offense is graded as a 2 nd degree crime, which has a maximum sentence of 10 years imprisonment. ${ }^{174}$

- Knowingly watching a dog fight ${ }^{175}$ is graded by New Jersey residents as similar in seriousness to intentionally giving another person a black eye, a disorderly persons offense, which has a maximum sentence of 6 months imprisonment, ${ }^{176}$ but under current law the offense is graded as a 3rd degree crime, which has a maximum sentence of 5 years imprisonment. ${ }^{177}$

- A prison guard knowingly giving a cell phone to an inmate ${ }^{178}$ is graded by New Jersey residents as similar in seriousness to intentionally causing another person emotional distress, a 4th degree crime, which has a maximum sentence of 18 months imprisonment, ${ }^{179}$ but under current law the offense is graded as a 2 nd degree crime, which has a maximum sentence of 10 years imprisonment. ${ }^{180}$

- Knowingly giving a ride to a homeless man from Atlantic County to Camden County and leaving the man in Camden County, without permission from either county welfare board, ${ }^{181}$ is graded by the New Jersey residents in the survey as similar in seriousness to fighting with another by mutual consent, a petty disorderly persons offense, which has a maximum sentence of 30 days imprisonment, ${ }^{182}$ but under current law the offense is graded as a 4 th degree crime, which has a maximum sentence of 18 months imprisonment. ${ }^{183}$

- Offering to pay for Super Bowl tickets for someone if that person votes for a preferred presidential candidate ${ }^{184}$ is graded by the New Jersey residents as similar in seriousness to intentionally giving another person a black eye, a disorderly persons offense, which has a maximum sentence of 6 months imprisonment, ${ }^{185}$ but under current law the offense is graded as a 3 rd degree crime, which has a maximum sentence of 5 years imprisonment. ${ }^{186}$

\footnotetext{
${ }^{172}$ N.J. Stat. Ann. §19:34-1.1a (West 2010).

${ }^{173}$ Mean $=3.53$, Median $=3, \mathrm{SD}=1.32($ See Appendix F, item A11).

${ }^{174}$ N.J. Stat. Ann. §2C:46-6a(2) (West 2010).

${ }^{175}$ N.J. Stat. Ann. $\$ 4: 22-24$ (West 2010).

${ }^{176}$ Mean $=2.77$, Median $=3, S D=1.43($ See Appendix F, item D3).

${ }^{177}$ N.J. Stat. Ann. §2C:46-6a(3) (West 2010).

${ }^{178}$ N.J. Stat. Ann. §2C:29-10(d) (West 2010).

${ }^{179}$ Mean $=3.52$, Median $=4, \mathrm{SD}=1.32$ (Appendix F, item A12).

${ }^{180}$ N.J. Stat. Ann. §2C:46-6a(2) (West 2010).

${ }^{181}$ N.J. Stat. Ann. \$44:4-79 (West 2010).

${ }^{182}$ Mean $=1.72$, Median $=1, \mathrm{SD}=1.23$ (Appendix F, item A13).

${ }^{183}$ N.J. Stat. Ann. \$2C:43-6a(4) (West 2010).

${ }^{184}$ N.J. Stat. Ann. $\$ 19: 34-25 j-k$ (West 2010).

${ }^{185}$ Mean $=2.83$, Median $=3, \mathrm{SD}=1.52($ Appendix F, item A14).

${ }^{186}$ N.J. Stat. Ann. §2C:43-6a(3) (West 2010).
} 
- A waiter not declaring his cash tips, which total $\$ 500$ for the year, intending to avoid some taxes, ${ }^{187}$ is graded by New Jersey residents as similar in seriousness to stealing $\$ 40$, a disorderly persons offense, which has a maximum sentence of 6 months imprisonment,${ }^{188}$ but under current law the offense is graded as a $3 \mathrm{rd}$ degree crime, which has a maximum sentence of 5 years imprisonment. ${ }^{189}$

- Knowingly buying a handgun and carrying it around without having permit for the gun ${ }^{190}$ is graded by New Jersey residents as similar in seriousness to intentionally causing another person emotional distress, a 4th degree crime, which has a maximum sentence of 18 months imprisonment,${ }^{191}$ but under current law the offense is graded as a 2 nd degree crime, which has a maximum sentence of 10 years imprisonment. ${ }^{192}$

- Knowingly giving a glass bong to a person under the age of $18^{193}$ is graded by New Jersey residents as similar in seriousness to intentionally giving another person a black eye, a disorderly persons offense, which has a maximum punishment of 6 months imprisonment ${ }^{194}$ but under current law the offense is graded as a 3rd degree crime, which has a maximum sentence of 5 years imprisonment. ${ }^{195}$

- Threatening to hurt a juror in an attempt to influence the jury in a murder trial ${ }^{196}$ is graded by New Jersey residents as similar in seriousness to intentionally slashing another person's shoulder with a knife, a 3rd degree crime, which has a maximum punishment of 5 years imprisonment, ${ }^{197}$ but under current law the offense is graded as a 1st degree crime, which has a maximum punishment of 20 years imprisonment. ${ }^{198}$

- A prisoner knowingly making a knife that can be used for escaping prison ${ }^{199}$ is graded by New Jersey residents as similar in seriousness to intentionally causing another person emotional distress, a 4th degree crime, which has a maximum punishment of 18 months imprisonment,${ }^{200}$ but under current law the offense is

${ }^{187}$ N.J. Stat. Ann. §54:52-8 (West 2010).

${ }^{188}$ Mean $=2.63$, Median $=3, \mathrm{SD}=1.21$ (Appendix F, item D7).

${ }^{189}$ N.J. Stat. Ann. §2C:43-6a(3) (West 2010).

${ }^{190}$ N.J. Stat. Ann. §2C:39-5b (West 2010).

${ }^{191}$ Mean $=3.98$, Median $=4, \mathrm{SD}=1.26$ (Appendix F, item A15).

${ }^{192}$ N.J. Stat. Ann. §2C:43-6a(2) (West 2010).

${ }^{193}$ N.J. Stat. Ann. §2C:36-5 (West 2010).

${ }^{194}$ Mean $=2.90$, Median $=3, \mathrm{SD}=1.39$ (Appendix F, item A16).

${ }^{195}$ N.J. Stat. Ann. §2C:43-6a(3) (West 2010).

${ }^{196}$ N.J. Stat. Ann. §2C:29-8a (West 2010).

${ }^{197}$ Mean $=4.93$, Median $=5, \mathrm{SD}=1.28$ (Appendix F, item A17).

${ }^{198}$ N.J. Stat. Ann. §2C:43-6a(1) (West 2010).

${ }^{199}$ N.J. Stat. Ann. §2C:29-6a (West 2010).

${ }^{200}$ Mean $=4.05$, Median $=4, S D=1.46($ Appendix F, item A18). 
graded as a 2 nd degree crime, which has a maximum punishment of 10 years imprisonment. $^{201}$

- An election official threatening to punch a voter unless the voter votes for a particular candidate $^{202}$ is graded by New Jersey residents in the survey as similar in seriousness to intentionally causing another person emotional distress, a 4 th degree crime, which has a maximum sentence of 18 months imprisonment, ${ }^{203}$ but under current law the offense is graded as a 2 nd degree crime, which has a maximum sentence of 10 years imprisonment. ${ }^{204}$

- Knowingly manufacturing 1 pound (about 1760 doses) of the illegal substance crystal meth $^{205}$ is graded by New Jersey residents as similar in seriousness to intentionally slashing another person's shoulder with a knife, a 3rd degree crime, which has a maximum sentence of 5 years imprisonment, ${ }^{206}$ but under current law the offense is currently graded as a 1 st degree crime, which has a maximum sentence of 20 years imprisonment. ${ }^{207}$

- A computer hacker purposefully breaking into the computer systems of a utility grid, and shutting down electricity for three city blocks ${ }^{208}$ is graded by New Jersey residents as similar in seriousness causing $\$ 25,000$ in property damage, a 3 rd degree crime, which has a maximum sentence of 5 years imprisonment, ${ }^{209}$ but under current law the offense is graded as a 1 st degree crime, which has a maximum sentence of 20 years imprisonment. ${ }^{210}$

- Possessing a legally purchased lottery ticket which costs $\$ 3$ and selling to a friend for $\$ 3,000$ the right to half of the ticket's winnings ${ }^{211}$ is graded by New Jersey residents as similar in seriousness to fighting by mutual consent, a petty disorderly persons offense, which has a maximum sentence of 30 days imprisonment ${ }^{212}$ but under current law selling whole or partial interests in lottery tickets above their fixed price is graded as a 4th degree crime, which has a maximum sentence of 18 months imprisonment. ${ }^{213}$

\footnotetext{
${ }^{201}$ N.J. Stat. Ann. §2C:43-6a(2) (West 2010).

${ }^{202}$ N.J. Stat. Ann. $\$ 19: 34-1.1 b$ (West 2010).

${ }^{203}$ Mean $=3.92$, Median $=4, \mathrm{SD}=1.33$ (Appendix F, item A19).

${ }^{204}$ N.J. Stat. Ann. §2C:43-6a(2) (West 2010).

${ }^{205}$ N.J. Stat. Ann. §2C:35-5b(8) (West 2010).

${ }^{206}$ Mean $=5.11$, Median $=5, \mathrm{SD}=1.20($ Appendix F, item A20).

${ }^{207}$ N.J. Stat. Ann. §2C:43-6a(1) (West 2010).

${ }^{208}$ N.J. Stat. Ann. §2C:20-25 (West 2010).

${ }^{209}$ Mean $=4.96$, Median $=5, \mathrm{SD}=1.02($ Appendix F, item A21)

${ }^{210}$ N.J. Stat. Ann. §2C:43-6a(1).

${ }^{211}$ N.J. Stat. Ann. §5:9-14 (West 2010).

${ }^{212}$ Mean $=1.93$, Median $=1, \mathrm{SD}=1.41($ Appendix F, item A23).

${ }^{213}$ N.J. Stat. Ann. §2C:43-6a(4) (West 2010).
} 
- Selling 500 doses of a date rape drug (“flunitrazepam”) to another person ${ }^{214}$ is graded by New Jersey residents as similar in seriousness to intentionally slashing another person's shoulder with a knife, a 3rd degree crime, which has a maximum sentence of 5 years imprisonment, ${ }^{215}$ but under current law the drug sale offense is graded as a 1st degree crime, which has a maximum sentence of 20 years imprisonment. ${ }^{216}$

- Hacking into someone's computer to get bank account details ${ }^{217}$ is graded by New Jersey residents as similar in seriousness to stealing $\$ 500$, a 4 th degree crime, which has a maximum sentence of 18 months imprisonment, ${ }^{218}$ but under current offense is graded as a 3 rd degree crime, which is has a maximum penalty of 5 years imprisonment. ${ }^{219}$

- A patient knowingly making 6 fraudulent health insurance claims, which add up to $\$ 2000^{220}$ is graded by New Jersey residents as similar in seriousness to stealing $\$ 500$, a 4 th degree crime, which has a maximum sentence of 5 years imprisonment, ${ }^{221}$ but under current law the offense is graded as a 2nd degree crime, which has a maximum sentence of 10 years imprisonment. ${ }^{222}$

- Knowingly selling pirated CDs, having already been convicted once before of this offense, ${ }^{223}$ is graded by New Jersey residents as similar in seriousness to stealing $\$ 40$, a disorderly persons offense, which has a maximum sentence of 6 months imprisonment ${ }^{224}$ but under current law the offense is graded as a 3rd degree crime, which has a maximum sentence of 5 years imprisonment. ${ }^{225}$

- An accused murderer threatening to hurt a potential witness against him to ensure that the witness will not testify ${ }^{226}$ is graded by New Jersey residents as similar in seriousness to intentionally slashing another person's shoulder with a knife, a 3rd degree crime, which has a maximum sentence of 5 years imprisonment, ${ }^{227}$ but under current law the offense is graded as a crime of the 1st degree, which has a maximum sentence of 20 years imprisonment. ${ }^{228}$

\footnotetext{
${ }^{214}$ N.J. Stat. Ann. §2C:35-5.3b (West 2010).

${ }^{215}$ Mean $=5.38$, Median $=5, \mathrm{SD}=1.12($ Appendix F, item A24).

${ }^{216}$ N.J. Stat. Ann. §2C:43-6a(1) (West 2010).

${ }^{217}$ N.J. Stat. Ann. §2C:20-25c (West 2010).

${ }^{218}$ Mean $=4.29$, Median $=4, \mathrm{SD}=1.00($ Appendix F, item A25).

${ }^{219}$ N.J. Stat. Ann. §2C:43-6a(3) (West 2010).

${ }^{220}$ N.J. Stat. Ann. §2C:21-4.3c (West 2010).

${ }^{221}$ Mean $=4.28$, Median $=4, \mathrm{SD}=0.78($ See Appendix F, item A26).

${ }^{222}$ N.J. Stat. Ann. §2C:43-6a(2) (West 2010).

${ }^{223}$ N.J. Stat. Ann. §2C:21-21c(4) (West 2010).

${ }^{224}$ Mean $=3.20$, Median $=3, \mathrm{SD}=1.07$ (Appendix F, item A27).

${ }^{225}$ N.J. Stat. Ann . §2C:43-6a(3) (West 2010).

${ }^{226}$ N.J. Stat. Ann. §2C:28-5a (West 2010).

${ }^{227}$ Mean $=5.30$, Median $=5, \mathrm{SD}=1.35$ (Appendix F, item A28).

${ }^{228}$ N.J. Stat. Ann. §2C:43-6a(1) (West 2010).
} 
- Offering a witness to a crime a new laptop, valued at $\$ 700$, in exchange for the witness not reporting an unrelated crime ${ }^{229}$ is graded by New Jersey residents as similar in seriousness to stealing $\$ 500$, a 4 th degree crime, which has a maximum sentence of 6 months imprisonment, ${ }^{230}$ but under current law the offense is graded as a 2 nd degree crime, which has a maximum sentence of 10 years imprisonment. ${ }^{231}$

- Standing outside of a train station offering to sell train tickets to someone, without written permission from railroad company ${ }^{232}$ is graded by New Jersey residents as similar in seriousness to intentionally annoying a person by making anonymous phone calls at $2 \mathrm{am}$, a petty disorderly persons offense, which has a maximum sentence of 30 days imprisonment, ${ }^{233}$ but under current law the offense has a maximum punishment of 1 year imprisonment. ${ }^{234}$

- Earning a living by making illegal loans at interest rates above those allowed by law ${ }^{235}$ is graded by New Jersey residents as similar in seriousness to stealing $\$ 500$, a 4th degree crime, which has a maximum sentence of 18 months imprisonment ${ }^{236}$ but under current law the offense is graded as a 2nd degree crime, which has a punishment of 10 years imprisonment. ${ }^{237}$

- Possessing a gram (about two doses) of marijuana ${ }^{238}$ is graded by the residents of New Jersey as similar in seriousness to fighting by mutual consent, a petty disorderly persons offense, which has a maximum sentence of 30 days imprisonment ${ }^{239}$ but under current law the possession of marijuana offense is graded as a disorderly persons offense, which has a maximum punishment of 6 months imprisonment. ${ }^{240}$

- For the second time in ten years, knowingly receiving Medicaid benefits totaling $\$ 2000$ after having been kicked out of the Medicaid program ${ }^{241}$ is graded by New Jersey residents as similar in seriousness to stealing $\$ 500$, a 4 th degree crime, which has a maximum punishment of 18 months imprisonment, ${ }^{242}$ but under current law, the offense is graded as a 2 nd degree crime, which has a maximum punishment of 10 years imprisonment. ${ }^{243}$

\footnotetext{
${ }^{229}$ N.J. Stat. Ann. §2C:29-4 (West 2010).

${ }^{230}$ Mean $=4.19$, Median $=4, \mathrm{SD}=1.20$ (Appendix F, item A29).

${ }^{231}$ N.J. Stat. Ann. §2C:43-6a(2) (West 2010).

${ }^{232}$ N.J. Stat. Ann. \$48:3-36 (West 2010).

${ }^{233}$ Mean $=2.38$, Median $=2, \mathrm{SD}=1.15$ (Appendix F, item A30).

${ }^{234}$ N.J. Stat. Ann. §48:3-36 (West 2010).

${ }^{235}$ N.J. Stat. Ann. §2C:21-19b (West 2010).

${ }^{236}$ Mean $=4.36$, Median $=5, \mathrm{SD}=1.32($ Appendix F, item A31).

${ }^{237}$ N.J. Stat. Ann. §2C:43-6a(2) (West 2010).

${ }^{238}$ N.J. Stat. Ann. §2C:35-10a(4) (West 2010).

${ }^{239}$ Mean $=2.11$, Median $=2, \mathrm{SD}=1.14($ Appendix F, item A32).

${ }^{240}$ N.J. Stat. Ann. §2C:43-6a(4) (West 2010).

${ }^{241}$ N.J. Stat. Ann. §30:4D-17 (West 2010).

${ }^{242}$ Mean $=4.00$, Median $=4, \mathrm{SD}=1.07$ (Appendix F, item A33).

${ }^{243}$ N.J. Stat. Ann. §2C:43-6a(2) (West 2010).
} 
- In an attempt to avoid being arrested, purposely threatening to beat up someone who might reveal one's location to police ${ }^{244}$ is graded by New Jersey residents as similar in seriousness to intentionally causing another person emotional distress, a 4th degree crime, which has a maximum punishment of 18 months imprisonment ${ }^{245}$ but under current law the offense is graded as a 2nd degree crime, which has a maximum punishment of 10 years imprisonment. ${ }^{246}$

- A doctor using a false name on a prescription in order to obtain drugs for personal use $^{247}$ is graded by New Jersey residents as similar in seriousness to intentionally causing another person emotional distress, a 4th degree crime, which has a maximum punishment of 18 months imprisonment, ${ }_{248}^{248}$ but under current law the offense is punished by up to 3 years imprisonment. ${ }^{249}$

- Manufacturing 10 ounces (about 2800 doses) of crack cocaine ${ }^{250}$ is graded by New Jersey residents in the survey as similar in seriousness to intentionally slashing another person's shoulder with a knife, a 3rd degree crime, which has a maximum punishment of 5 years imprisonment, ${ }^{251}$ but under current law the offense is graded as a crime of the 1 st degree, which has a maximum punishment of 20 years imprisonment. ${ }^{252}$

- Knowingly manufacturing one gram (20,000 doses) of the drug $\operatorname{LSD}^{253}$ is graded by New Jersey residents as similar in seriousness to intentionally slashing another person's shoulder with a knife, a 3rd degree crime, which has a maximum punishment of 5 years imprisonment, ${ }^{254}$ but under current law the LSD manufacturing offense is graded as a 1 st degree crime, which has a maximum punishment of 20 years imprisonment. ${ }^{255}$

- A scientist who researches anthrax accidentally leaving the door to his laboratory unlocked one night, allowing an unauthorized person to take a sample of the anthrax, ${ }^{256}$ is graded by New Jersey residents as similar in seriousness to intentionally causing another person emotional distress, a 4th degree crime, which has a maximum punishment of 18 months imprisonment, ${ }^{257}$ but under current law

\footnotetext{
${ }^{244}$ N.J. Stat. Ann. §2C:29-3b (West 2010).

${ }^{245}$ Mean $=4.15$, Median $=4, \mathrm{SD}=1.22($ Appendix F, item A34).

${ }^{246}$ N.J. Stat. Ann. §2C:43-6a(2) (West 2010).

${ }^{247}$ N.J. Stat. Ann. $\$ 24: 21-22$ (West 2010).

${ }^{248}$ Mean $=4.09$, Median $=4, \mathrm{SD}=1.23$ (Appendix F, item A35).

${ }^{249}$ N.J. Stat. Ann. $24: 21-22$ (West 2010).

${ }^{250}$ N.J. Stat. Ann. §2C:35-5b(1) (West 2010).

${ }^{251}$ Mean $=4.99$, Median $=5, \mathrm{SD}=1.27$ (Appendix F, item A36).

${ }^{252}$ N.J. Stat. Ann. §2C:43-6a(1) (West 2010).

${ }^{253}$ N.J. Stat. Ann. §2C:35-5b(6) (West 2010).

${ }^{254}$ Mean $=4.81$, Median $=5, \mathrm{SD}=1.41($ Appendix F, item A37).

${ }^{255}$ N.J. Stat. Ann. §2C:43-6a(1) (West 2010).

${ }^{256}$ N.J. Stat. Ann. §2C:38-3b (West 2010).

${ }^{257}$ Mean $=3.78$, Median $=4, \mathrm{SD}=2.11($ Appendix F, item A38).
} 
the offense is graded as a 2nd degree crime, which has a maximum punishment of 10 years imprisonment. ${ }^{258}$

- A person who has been disqualified from voting knowingly voting in an election $^{259}$ is graded by New Jersey residents as similar in seriousness to running naked in a public place, a disorderly persons offense, which has a maximum punishment of 6 months imprisonment, ${ }^{260}$ but under current law the offense is graded as a $3 \mathrm{rd}$ degree crime, which has a maximum punishment of 5 years imprisonment. $^{261}$

Offenses Grade by New Jersey Residents Higher Than Current Law:

- Knowingly selling oil-burning camping stoves which do not have safety valves to shut off the stoves if they tip over, creating a risk of a fire ${ }^{262}$ is graded by New Jersey residents as the same seriousness as intentionally causing another person emotional distress, a 4th degree crime, which has a maximum sentence of 18 months imprisonment, ${ }^{263}$ but under current law the selling of dangerous stoves offense is graded as a petty disorderly persons offense, which has a maximum sentence of 30 days imprisonment. ${ }^{264}$

- Knowingly selling oil-burning camping stoves that create so much carbon dioxide when they are used that they become hazardous ${ }^{265}$ is graded by New Jersey residents as similar in seriousness to intentionally causing another person emotional distress, a 4th degree crime, which has a maximum punishment of 18 months imprisonment, ${ }^{266}$ but under current law the sale of hazardous stoves offense is graded as a petty disorderly persons offense, which has a maximum punishment of 30 days imprisonment. ${ }^{267}$

- A third offense of knowingly driving a car through a school zone while drunk ${ }^{268}$ is graded by New Jersey residents as the same seriousness as intentionally causing another person emotional distress, a 3rd degree crime, which has a maximum sentence of 5 years imprisonment, ${ }^{269}$ but under current law the offense has a maximum sentence of 180 days imprisonment. ${ }^{270}$

${ }^{258}$ N.J. Stat. Ann. §2C:43-6a(2) (West 2010).

${ }^{259}$ N.J. Stat. Ann. §19:34-20 (West 2010).

${ }^{260}$ Mean $=2.89$, Median $=3, \mathrm{SD}=1.20($ Appendix F, item A39).

${ }^{261}$ N.J. Stat. Ann. §2C:43-6a(3) (West 2010).

${ }^{262}$ N.J. Stat. Ann. §2C:40-11 (West 2010); N.J. Stat. Ann. §2C:40-15 (West 2010).

${ }^{263}$ Mean $=3.96$, Median $=4, \mathrm{SD}=1.59$ (Appendix F, item A40).

${ }^{264}$ N.J. Stat. Ann. §2C:43-8 (West 2010).

${ }^{265}$ N.J. Stat. Ann. §2C:40-12 (West 2010); N.J. Stat. Ann. §2C:40-15 (West 2010).

${ }^{266}$ Mean $=4.22$, Median $=4, \mathrm{SD}=1.60$ (Appendix F, item A41).

${ }^{267}$ N.J. Stat. Ann. §2C:43-8 (West 2010).

${ }^{268}$ N.J. Stat. Ann. §39:4-50g(3) (West 2010).

${ }^{269}$ Mean $=5.31$, Median $=5, \mathrm{SD}=1.22($ Appendix F, item A42).

${ }^{270}$ N.J. Stat. Ann. §2C:43-6a(3) (West 2010). 


\section{Appendix B: More Examples of the Mandatory Minimum Problem}

- New Jersey residents graded knowingly agreeing to buy a $\$ 600,000$ house with a mortgage in the offender's name for a known drug dealer who pays the offender back in cash $^{271}$ as a crime similar in stealing $\$ 500$, which has a maximum penalty of 18 months. ${ }^{272}$ Yet, current law sets the mandatory minimum for the offense at 3 years and 4 months. ${ }^{273}$

- New Jersey residents graded a government contractor knowingly lying about his professional certifications in negotiations for a $\$ 30,000$ contract $^{274}$ as similar in seriousness to causing $\$ 500$ in property damage, which has a maximum penalty of 18 months. ${ }^{275}$ Yet, current law sets the mandatory minimum for the offense at 5 years. ${ }^{276}$

- New Jersey residents graded an employee for the local zoning board knowingly purchasing a house in a residential area that he has found out through non-public information has just been rezoned to have a diner, which increases the property value by $\$ 10,000,{ }^{277}$ as similar in seriousness to stealing $\$ 500$, which has a maximum penalty of 18 months. ${ }^{278}$ Yet, current law sets the mandatory minimum for the offense at 5 years. ${ }^{279}$

- New Jersey residents graded knowingly having a rifle in a house without a proper firearms permit ${ }^{280}$ as similar in seriousness to intentionally causing another person emotional distress, which has a maximum penalty of 6 months. ${ }^{281}$ Yet, current law sets the mandatory minimum for the offense at 3 years. ${ }^{282}$

\footnotetext{
${ }^{271}$ N.J. Stat. Ann. §2C:21-25 (West 2010).

272 Mean $=4.22$, Median $=5, \mathrm{SD}=1.60$ (Appendix F, item B6).

${ }^{273}$ N.J. Stat. Ann. §2C:21-27 (West 2010). The statute provides that the minimum term will be "fixed at, or between, one-third and one-half of the sentence imposed." Since this is a first-degree crime with a sentence range of 10 to 20 years, even the lowest minimum term of one-third of the sentence imposed would result in a mandatory minimum of 3 years and 4 months.

${ }^{274}$ N.J. Stat. Ann. §2C:21-34b (West 2010).

${ }^{275}$ Mean $=4.27$, Mode $=4, \mathrm{SD}=1.13$ (Appendix F, item B7).

${ }^{276}$ N.J. Stat. Ann. §2C:43-6.5b(7) (West 2010).

${ }^{277}$ N.J. Stat. Ann. $\S 2 \mathrm{C}: 30-3$ (West 2010).

${ }^{278}$ Mean $=3.25$, Mode $=4, \mathrm{SD}=1.64($ Appendix F, item B8).

${ }^{279}$ N.J. Stat. Ann. §2C:43-6.5b(18) (West 2010).

${ }^{280}$ N.J. Stat. Ann. §2C:39-5c (West 2010).d

${ }^{281}$ Mean $=3.35$, Mode $=3, \mathrm{SD}=1.28($ Appendix F, item E5).

${ }^{282}$ N.J. Stat. Ann. §2C:43-6c (West 2010).
} 


\section{Appendix C: More Examples of the Problem of Failing to Distinguish Conduct of Significantly Different Seriousness Contained Within a Single Offense Grade}

- An industrial farmer who knowingly files a renewal application to divert water for irrigation after the deadline would be punished under the same statute as a company that provides substandard drinking water to homes. ${ }^{283}$ Under current law, both would be guilty of a 3 rd degree crime, with a maximum sentence of 5 years ${ }^{284}$ but New Jersey residents graded the first scenario as a petty disorderly persons offense, with a maximum sentence of 30 days, ${ }^{285}$ and the second scenario as a 3 rd degree offense, with a maximum sentence of 5 years. ${ }^{286}$

- A funeral home director who, in a hospital, hands a business card to a person who has just learned that a family member is going to die, would be punished under the same statute as an embalmer who injects arsenic into a cadaver of a person who dies under suspicious circumstances to prevent the detection of the cause of death. ${ }^{287}$ Under current law, both individuals would be guilty of a 4 th degree crime, with a maximum sentence of 18 months, ${ }^{288}$ but New Jersey residents graded first scenario as a petty disorderly persons offense, with a maximum sentence of 30 days, ${ }^{289}$ and the second scenario as a 3rd degree crime, with a maximum sentence of 5 years. ${ }^{290}$

- Creating a fake label for prescription hair loss medication so that others do not know what the medicine is for is punished under the same statute as bringing 5,000 prescription painkiller pills into the state with the intention of selling them without prescriptions. ${ }^{291}$ Under current law, both actions would be punished as 3 rd degree crimes, with a maximum sentence of 5 years, ${ }^{292}$ but New Jersey residents graded the first scenario as a petty disorderly persons offense, with a maximum sentence of 30 days, ${ }^{293}$ and graded the second scenario as a 3 rd degree crime, with a maximum sentence of 5 years. ${ }^{294}$

- A county animal control officer who provides the owner of a shampoo company with a dog from the pound to test how the shampoo works on fur is punished under the same statute as one who allows a researcher to use a captured stray to determine whether death occurs more quickly from electric shock or

\footnotetext{
${ }^{283}$ N.J. Stat. Ann. §58:1A-16f (West 2010) (Violations of provisions regarding water supply management).

${ }^{284} \mathrm{Id}$.

${ }^{285}$ Mean $=2.26$, Median $=2, \mathrm{SD}=1.38($ Appendix F, item D11 $)$

${ }^{286}$ Mean $=5.05$, Median $=5, \mathrm{SD}=1.30($ Appendix F, item D12).

${ }^{287}$ N.J. Stat. Ann. $\S 45: 7-65.5$ (West 2010) (Violations of provisions regarding embalmers and funeral directors).

${ }^{288} \mathrm{Id}$.

${ }^{289}$ Mean $=1.78$, Median $=1, \mathrm{SD}=1.28($ Appendix F, item D13).

${ }^{290}$ Mean $=4.89$, Median $=5, \mathrm{SD}=1.33$ (Appendix F, item D14).

${ }^{291}$ N.J. Stat. Ann. §24:6B-29a (West 2010) (Violations applicable to prescription drug distribution).

${ }^{292} I d$.

${ }^{293}$ Mean $=1.54$, Median $=1, \mathrm{SD}=0.96($ Appendix F, item D15).

${ }^{294}$ Mean $=4.63$, Median $=5, \mathrm{SD}=1.32($ Appendix F, item D16).
} 
decapitation. ${ }^{295}$ Under current law, both would be guilty of a 4th degree crime, with a maximum term of imprisonment of 18 months,${ }^{296}$ but New Jersey residents graded the first scenario as a 4th degree crime with a maximum sentence of 18 months,${ }^{297}$ and graded the second scenario as a 3 rd degree crime, with a maximum sentence 5 years. ${ }^{298}$

- Combining two weeks worth of multiple prescription medications provided to by a doctor into a single bottle to save space while travelling would be punished under the same statute as having a month's worth of a prescription narcotic that was obtained illegally. ${ }^{299}$ Under current law, both actions are graded as a disorderly persons offense, with a maximum sentence of 6 months, ${ }^{300}$ but New Jersey residents graded the first scenario as a petty disorderly persons offense, with a maximum sentence of 30 days, ${ }^{301}$ and graded the second as a disorderly persons offense, with a maximum sentence of 6 months. ${ }^{302}$

- Selling one dose of a hallucinogenic drug to another who then kills himself during a "bad trip" would be punished under the same statute selling multiple doses of a particularly potent heroin that causes an addict to overdose and die. ${ }^{303}$ Under current law, both actions are punished as 1 st degree crimes ${ }^{304}$ with a maximum punishment of 20 years. However, New Jersey residents graded the first scenario as a 3 rd degree crime, with a maximum punishment of 5 years, ${ }^{305}$ and the second as a 2 nd degree crime, with a maximum punishment of 10 years. ${ }^{306}$

\footnotetext{
${ }^{295}$ N.J. Stat. Ann. §4:19-15.16 (West 2010) (Availability of dogs or other animals for experimentation prohibited).

${ }^{296} I d$.

${ }^{297}$ Mean $=3.47$, Median $=3.5, \mathrm{SD}=1.61($ Appendix F, item D17).

${ }^{298}$ Mean $=5.19$, Median $=5, \mathrm{SD}=1.57$ (Appendix F, item D18).

${ }^{299}$ N.J. Stat. Ann. §2C:35-24 (West 2010) (Possession of certain prescription drugs).

${ }^{300} \mathrm{Id}$.

${ }^{301}$ Mean $=1.68$, Median $=1, \mathrm{SD}=1.31($ Appendix F, item D19).

${ }^{302}$ Mean $=3.32$, Median $=3, \mathrm{SD}=1.34($ Appendix F, item D20).

${ }^{303}$ N.J. Stat. Ann. §2C: 35-9 (West 2010) (Strict liability for drug-induced deaths).

${ }^{304} \mathrm{Id}$.

${ }^{305}$ Mean $=5.19$, Median $=6, S D=1.69($ Appendix F, item D21).

${ }^{306}$ Mean $=5.55$, Median $=6, \mathrm{SD}=1.47$ (Appendix F, item D22).
} 


\section{Appendix D: More Examples of the Problem of Too Few Grading Categories}

- A lawyer hiring someone to convince patients at an emergency room to hire the lawyer for a personal injury suit ${ }^{307}$ and a lawyer personally visiting the damaged homes of tornado victims to offer them legal services ${ }^{308}$ are each graded as 3rd degree crimes. New Jersey residents, however, view these two acts very differently, grading the lawyer hiring someone to go to the emergency room as similar to intentionally giving another person a black eye, a disorderly persons offense, ${ }^{309}$ and the lawyer visiting the damaged homes as not deserving of punishment. ${ }^{310}$

- Earning a living by making illegal loans at rates above the legal interest rate ${ }^{311}$ and making a single $\$ 5000$ loan to a friend that charges him a $55 \%$ interest rate ${ }^{312}$ are both 2 nd degree crimes. New Jersey residents, however, view this conduct differently, grading earning a living through illegal loans as being similar to stealing $\$ 500$, a 4 th degree crime, ${ }^{313}$ and making a single loan at a high interest rate as being similar to stealing $\$ 40$, a disorderly persons offense. ${ }^{314}$

- Knowingly having a marijuana operation which has produced 60 pounds of marijuana (about 13,600 doses and a street value of $\$ 180,000)^{315}$ and knowingly growing 15 marijuana plants in a personal greenhouse ${ }^{316}$ are each graded as $1 \mathrm{st}$ degree crimes. New Jersey residents, however, view the conduct differently, grading having a marijuana operation that produces 60 pounds of marijuana as similar to stealing $\$ 500$, a 4 th degree crime, ${ }^{317}$ and growing 15 marijuana plants in a personal greenhouse as similar to stealing $\$ 40$, a disorderly persons offense. $^{318}$

- Knowingly having 1 gram of morphine outside of a medical facility without a prescription $^{319}$ and using an extra prescription slip attached to an actual prescription to obtain pain pills from a pharmacy ${ }^{320}$ are each graded as 3rd degree crimes. New Jersey residents, however, view these crimes as different, grading knowingly having 1 gram of morphine outside of a medical facility as similar to

\footnotetext{
${ }^{307}$ N.J. Stat. Ann. §2C:21-22.1 (West 2010) (Hiring a runner for fraudulent practices).

${ }^{308}$ N.J. Stat. Ann. §2C:40A-5 (West 2010) (Violation of professional employment).

${ }^{309}$ Mean $=2.78$, Median $=3, \mathrm{SD}=1.55$ (Appendix F, item E8).

${ }^{310}$ Mean $=1.42$, Median $=1, \mathrm{SD}=1.05$ (Appendix F, item E9).

${ }^{311}$ N.J. Stat. Ann. §2C:21-19(b) (West 2010) (Business of criminal usury).

${ }^{312}$ N.J. Stat. Ann. §2C:21-19(a) (West 2010) (Criminal usury).

${ }^{313}$ Mean $=4.36$, Median $=5, \mathrm{SD}=1.32$. (Appendix F, item A31).

${ }^{314}$ Mean $=3.24$, Median $=4, \mathrm{SD}=1.58$. (Appendix F, item E10).

${ }^{315}$ N.J. Stat. Ann. $\$ 2 C: 35-5(b)(10)(a)$ (West 2010) (Manufacturing, distributing, or dispensing marijuana).

${ }^{316}$ N.J. Stat. Ann. \$2C:35-4 (West 2010) (Maintaining or operating a controlled substance production facility).

${ }^{317}$ Mean $=4.46$, Median $=5, \mathrm{SD}=1.71($ Appendix F, item E11).

${ }^{318}$ Mean $=3.01$, Median $=3, \mathrm{SD}=1.52($ Appendix F, item B5)

${ }^{319}$ N.J. Stat. Ann. $\$ 2 C: 35-5(b)(5)$ (West 2010) (Manufacturing, distributing, or dispensing narcotic drug).

${ }^{320}$ N.J. Stat. Ann. §2C:35-13 (West 2010) (Obtaining by fraud controlled substances).
} 
intentionally giving another person a black eye, a disorderly persons offense, ${ }^{321}$ and using an extra prescription slip to obtain pain pills as similar to intentionally causing another person emotional distress, a 4th degree crime. ${ }^{322}$

- Knowingly selling another person a forged birth certificate ${ }^{323}$ and knowingly owning paper, a machine, and a seal that can be used to make forged birth certificates $^{324}$ are each graded as 2 nd degree crimes. New Jersey residents, however, view these crimes differently, grading selling a forged birth certificate as similar to intentionally causing another person emotional distress, a 4th degree crime, ${ }^{325}$ and knowingly owning the tools to make forged birth certificates as similar to causing $\$ 40$ in property damage, a disorderly persons offense. ${ }^{326}$

- Placing an advertisement in the newspaper to sell glass pipes that are intended for smoking marijuana ${ }^{327}$ and possessing 2 ounces of marijuana which has a street value of about $\$ 500$ and is enough to roll 100 joints ${ }^{328}$ are each graded as 4 th degree crimes. New Jersey residents, however, view these crimes as different, grading placing the advertisement as similar to fighting with another by mutual consent, a petty disorderly persons offense, ${ }^{329}$ and possessing 2 ounces of marijuana as similar to intentionally giving another person a black eye, a disorderly persons offense. ${ }^{330}$

${ }^{321}$ Mean $=3.30$, Median $=3, \mathrm{SD}=1.35($ Appendix F, item E12).

${ }^{322}$ Mean $=3.59$, Median $=4, \mathrm{SD}=1.12($ Appendix F, item E13).

${ }^{323}$ N.J. Stat. Ann. §2C:21-2.1a (West 2010) (Forgery of birth certificate).

${ }^{324}$ N.J. Stat. Ann. §2C:21-2.1b (West 2010) (Forgery of birth certificate).

${ }^{325}$ Mean $=4.11$, Median $=4, \mathrm{SD}=1.08$ (Appendix F, item E14).

${ }^{326}$ Mean $=3.47$, Median $=4, \mathrm{SD}=1.81($ Appendix F, item E15).

${ }^{327}$ N.J. Stat. Ann. $\$ 2 \mathrm{C}: 36-4$ (West 2010) (Advertising to promote the sale of drug paraphernalia).

${ }^{328}$ N.J. Stat. Ann. §2C:35-10a(3) (West 2010) (Possession of marijuana).

${ }^{329}$ Mean $=2.08$, Median $=1, \mathrm{SD}=1.38($ Appendix F, item E16).

${ }^{330}$ Mean $=2.98$, Median $=3, \mathrm{SD}=1.44($ Appendix F, item E17). 


\section{Appendix E: Increasing Rate of Amendments to New Jersey Criminal Law}

Table 1: Total Amendments Made to Criminal Offenses (1980-2009) ${ }^{331}$

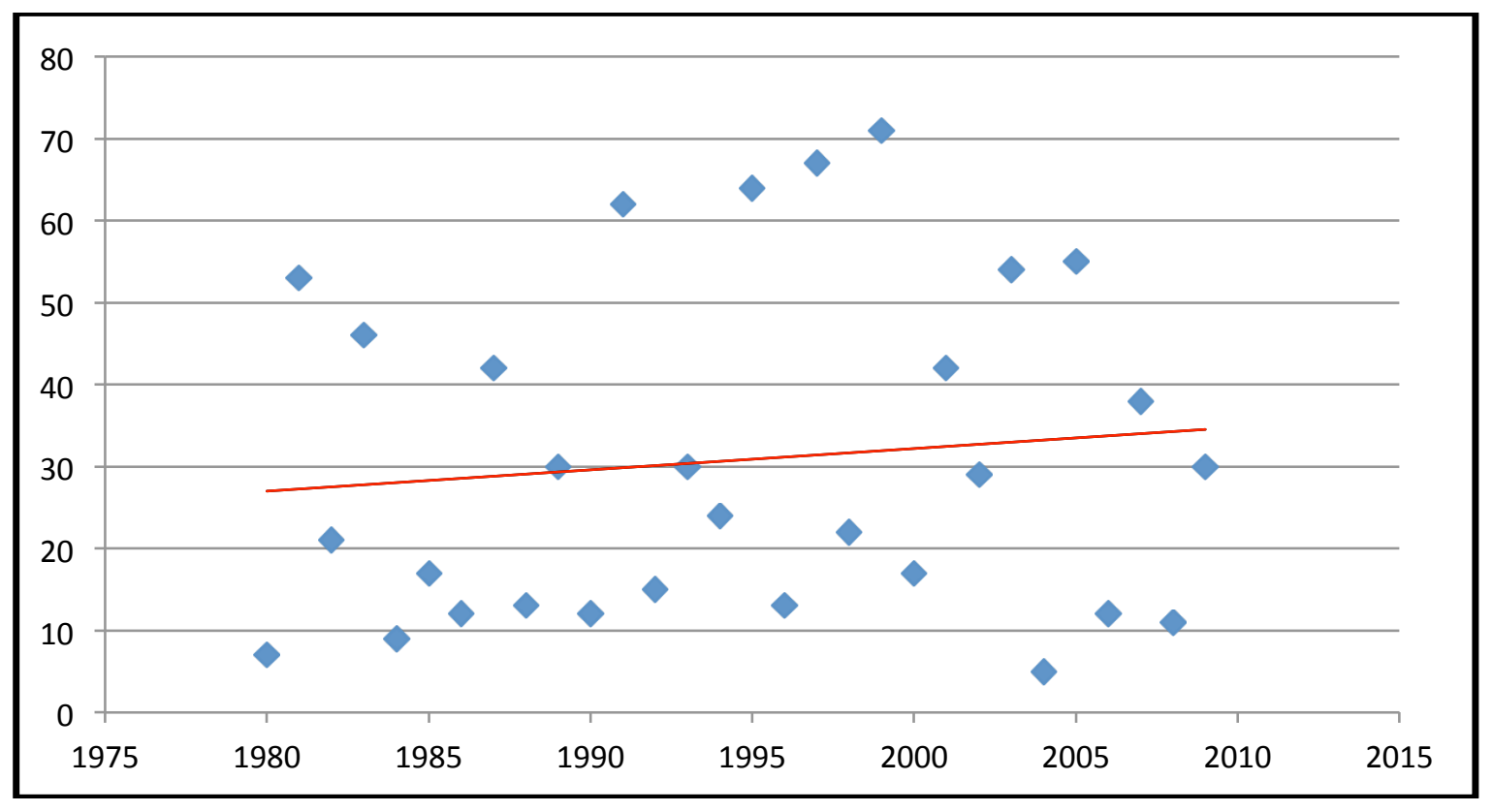

Table 2: Total Amendments Made to Title 2C Offenses (1980-2009)

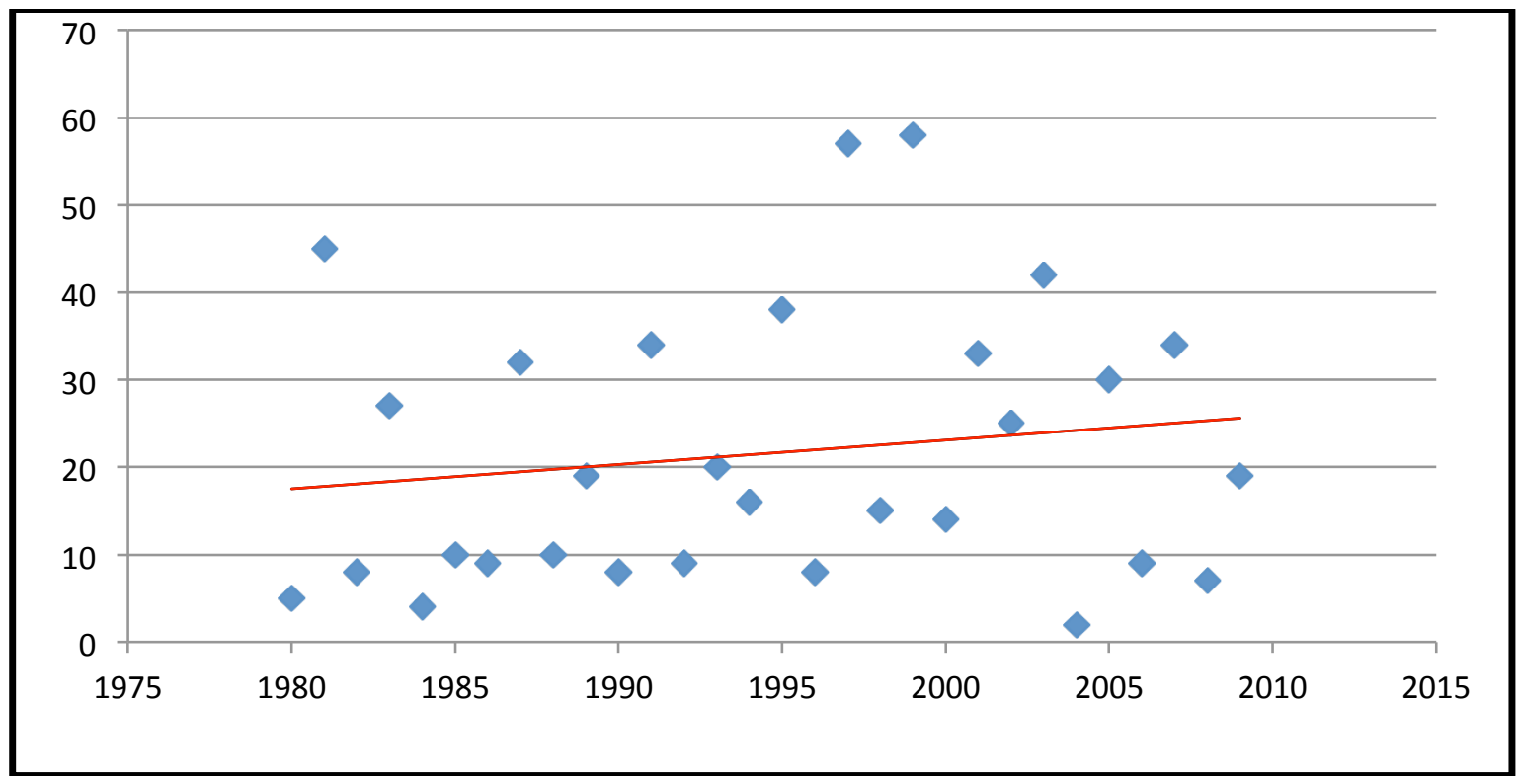

${ }^{331}$ The amendments added in 1979, the year after Title $2 \mathrm{C}$ was enacted, were not included in this analysis, as they became effective on September 1, 1979 - at the same time as the Code. The amendment count includes both the creation of new offenses and the modification of old ones. 


\section{Appendix F: Survey Results}

\section{Table 1: Non-Broad Offenses}

\begin{tabular}{|c|c|c|c|c|c|c|c|c|c|}
\hline $\begin{array}{l}\text { Reference } \\
\text { Number }\end{array}$ & ID & Section & Title & NJ Grade & Translated & Mean & Median & SD & Difference $^{332}$ \\
\hline A1 & X2_319 & $34: 20-5$ & $\begin{array}{l}\text { Penalties for improper } \\
\text { classification of an } \\
\text { employee }\end{array}$ & $\begin{array}{l}\text { 2nd } \\
\text { Degree }\end{array}$ & 6 & 3.46 & 4 & 1.52 & $2 *$ \\
\hline A2 & X3_342 & $2 \mathrm{C}: 15-2 \mathrm{a}$ & Carjacking & 1st Degree & 7 & 5.23 & 5 & 0.66 & $2 *$ \\
\hline A3 & X2_377 & $2 \mathrm{C}: 40-17 \mathrm{a}$ & Tampering & \begin{tabular}{|l|} 
3rd \\
Degree
\end{tabular} & 5 & 1.99 & 2 & 0.92 & $3 *$ \\
\hline A4 & X0_316 & 2B:21-10 & $\begin{array}{l}\text { Unauthorized disclosure of } \\
\text { grand jury proceedings }\end{array}$ & \begin{tabular}{|l} 
th \\
Degree
\end{tabular} & 4 & 5.60 & 6 & 1.30 & $-2 *$ \\
\hline A5 & $\mathrm{X} 2 \_313$ & $26: 2 \mathrm{D}-22$ & $\begin{array}{l}\text { Radiation Protection Act: } \\
\text { Violations }\end{array}$ & $\begin{array}{l}\text { 4th } \\
\text { Degree }\end{array}$ & 4 & 5.57 & 6 & 1.25 & $-2 *$ \\
\hline A6 & X3_343 & $2 \mathrm{C}: 17-2 \mathrm{c}$ & $\begin{array}{l}\text { Causing or risking } \\
\text { widespread injury or } \\
\text { damage }\end{array}$ & $\begin{array}{l}\text { 3rd } \\
\text { Degree }\end{array}$ & 5 & 3.02 & 3 & 1.80 & $2 *$ \\
\hline A7 & X1_400 & $2 \mathrm{C}: 39-11 \mathrm{a}$ & $\begin{array}{l}\text { Pawnbrokers; loaning on } \\
\text { firearms }\end{array}$ & $\begin{array}{l}\text { 3rd } \\
\text { Degree }\end{array}$ & 5 & 2.69 & 2 & 1.75 & $3 *$ \\
\hline A8 & X1_396 & $\begin{array}{l}2 \mathrm{C}: 35- \\
5 \mathrm{~b}(10)(\mathrm{b})\end{array}$ & $\begin{array}{l}\text { Manufacturing, } \\
\text { distributing or dispensing } \\
\text { marijuana }\end{array}$ & $\begin{array}{l}\text { 2nd } \\
\text { Degree }\end{array}$ & 6 & 3.57 & 4 & 1.56 & $2 *$ \\
\hline A9 & X1_365 & $2 C: 33-28 \mathrm{e}$ & $\begin{array}{l}\text { Solicitation, recruitment to } \\
\text { join criminal street gang }\end{array}$ & $\begin{array}{l}\text { 2nd } \\
\text { Degree }\end{array}$ & 6 & 3.42 & 4 & 1.65 & $2 *$ \\
\hline A10 & X4_421 & $\begin{array}{l}2 \mathrm{C}: 35- \\
10 \mathrm{a}(1)\end{array}$ & $\begin{array}{l}\text { Possession, use or being } \\
\text { under the influence, or } \\
\text { failure to make lawful } \\
\text { disposition }\end{array}$ & $\begin{array}{l}\text { 3rd } \\
\text { Degree }\end{array}$ & 5 & 2.90 & 3 & 1.21 & $2 *$ \\
\hline A11 & X3_307 & $19: 34-1.1 \mathrm{a}$ & $\begin{array}{l}\text { Enforcement of election } \\
\text { law: violations; penalties }\end{array}$ & $\begin{array}{l}\text { 2nd } \\
\text { Degree }\end{array}$ & 6 & 3.53 & 3 & 1.32 & $3 *$ \\
\hline A12 & X3_357 & $2 \mathrm{C}: 29-10 \mathrm{~d}$ & $\begin{array}{l}\text { Electronic communication } \\
\text { devices in correctional } \\
\text { facilities }\end{array}$ & $\begin{array}{l}\text { 2nd } \\
\text { Degree }\end{array}$ & 6 & 3.52 & 4 & 1.32 & $2 *$ \\
\hline A13 & X0_325 & $44: 4-79$ & $\begin{array}{l}\text { Bringing poor person into } \\
\text { municipality }\end{array}$ & $\begin{array}{l}\text { 4th } \\
\text { Degree }\end{array}$ & 4 & 1.72 & 1 & 1.23 & $3^{*}$ \\
\hline A14 & X3_308 & $\begin{array}{l}\text { 19:34-25j.- } \\
\mathrm{k}\end{array}$ & Bribery & $\begin{array}{l}\text { 3rd } \\
\text { Degree }\end{array}$ & 5 & 2.83 & 3 & 1.52 & $2 *$ \\
\hline A15 & X2_402 & $2 C: 39-5 b$ & $\begin{array}{l}\text { Unlawful possession of } \\
\text { weapons }\end{array}$ & $\begin{array}{l}\text { 2nd } \\
\text { Degree }\end{array}$ & 6 & 3.98 & 4 & 1.26 & $2^{*}$ \\
\hline
\end{tabular}

${ }^{332}$ An asterisk indicates statistical significance of the difference between the sampled median and the legislative grade at the 0.05 level based upon the method described supra at note 128 . If the t-test is used instead as a measure of statistical significance of the difference between the sample mean and the legislative grade, the following additional questions exhibit statistical significance: X1_339, X1_375, X2_392. 


\begin{tabular}{|c|c|c|c|c|c|c|c|c|c|}
\hline A16 & $\mathrm{X} 0 \_371$ & $2 C: 36-5$ & $\begin{array}{l}\text { Delivering drug } \\
\text { paraphernalia to person } \\
\text { under } 18\end{array}$ & $\begin{array}{l}\text { 3rd } \\
\text { Degree }\end{array}$ & 5 & 2.90 & 3 & 1.39 & $2 *$ \\
\hline A17 & X2_361 & $2 C: 29-8 \mathrm{a}$ & $\begin{array}{l}\text { Corrupting or influencing a } \\
\text { jury }\end{array}$ & 1st Degree & 7 & 4.93 & 5 & 1.28 & $2 *$ \\
\hline A18 & X0_360 & $2 C: 29-6 a$ & Implements for escape & $\begin{array}{l}\text { 2nd } \\
\text { Degree }\end{array}$ & 6 & 4.05 & 4 & 1.46 & $2 *$ \\
\hline A19 & X0_307 & $19: 34-1.1 b$ & $\begin{array}{l}\text { Enforcement of election } \\
\text { law: violations; penalties }\end{array}$ & $\begin{array}{l}\text { 2nd } \\
\text { Degree }\end{array}$ & 6 & 3.92 & 4 & 1.33 & $2 *$ \\
\hline A20 & X3_398 & $\begin{array}{l}2 \mathrm{C}: 35- \\
5 \mathrm{~b}(8)\end{array}$ & $\begin{array}{l}\text { Manufacturing, } \\
\text { distributing or dispensing } \\
\text { methamphetamine }\end{array}$ & 1st Degree & 7 & 5.11 & 5 & 1.20 & $2 *$ \\
\hline A21 & $\mathrm{X} 3 \_382$ & 2C:20-25 & Computer criminal activity & 1st Degree & 7 & 4.96 & 5 & 1.02 & $2 *$ \\
\hline A23 & X3_332 & $5: 9-14$ & $\begin{array}{l}\text { Lottery ticket: Sale above } \\
\text { fixed price; unlicensed } \\
\text { sales; gifts }\end{array}$ & $\begin{array}{l}\text { 4th } \\
\text { Degree }\end{array}$ & 4 & 1.93 & 1 & 1.41 & $3 *$ \\
\hline A24 & X3_370 & $2 C: 35-5.3 b$ & $\begin{array}{l}\text { Manufacturing, } \\
\text { flunitrazepam }\end{array}$ & 1st Degree & 7 & 5.38 & 5 & 1.12 & $2^{*}$ \\
\hline A25 & X3_346 & $2 C: 20-25 c$ & Computer criminal activity & $\begin{array}{l}\text { 3rd } \\
\text { Degree }\end{array}$ & 5 & 4.29 & 4 & 1.00 & $1^{*}$ \\
\hline A26 & X1_387 & $2 \mathrm{C}: 21-4.3 \mathrm{a}$ & $\begin{array}{l}\text { Health care claims fraud, } \\
\text { degree of crime; } \\
\text { prosecution guidelines }\end{array}$ & $\begin{array}{l}\text { 2nd } \\
\text { Degree }\end{array}$ & 6 & 4.59 & 5 & 0.96 & $1 *$ \\
\hline A27 & $\mathrm{X} 2 \_350$ & $2 C: 21-21$ & Piracy & $\begin{array}{l}\text { 3rd } \\
\text { Degree }\end{array}$ & 5 & 3.20 & 3 & 1.07 & $2 *$ \\
\hline A28 & X3_355 & $2 C: 28-5 a$ & $\begin{array}{l}\text { Tampering with witnesses } \\
\text { and informants; retaliation }\end{array}$ & 1st Degree & 7 & 5.30 & 5 & 1.35 & $2 *$ \\
\hline A29 & X3_359 & 2C:29-4 & Compounding & $\begin{array}{l}\text { 2nd } \\
\text { Degree }\end{array}$ & 6 & 4.19 & 4 & 1.20 & $2 *$ \\
\hline $\mathrm{A} 30$ & X1_329 & $48: 3-36$ & $\begin{array}{l}\text { Ticket agents; certificate of } \\
\text { authority; selling without } \\
\text { certificate; penalty }\end{array}$ & $\begin{array}{l}\text { 4th } \\
\text { Degree }\end{array}$ & 4 & 2.38 & 2 & 1.15 & $2 *$ \\
\hline A31 & X1_348 & $2 C: 21-19 b$ & Business of criminal usury & $\begin{array}{l}\text { 2nd } \\
\text { Degree }\end{array}$ & 6 & 4.36 & 5 & 1.32 & $1 *$ \\
\hline A32 & X3_397 & $\begin{array}{l}2 \mathrm{C}: 35- \\
10 \mathrm{a}(4)\end{array}$ & $\begin{array}{l}\text { Possession, use or being } \\
\text { under the influence, or } \\
\text { failure to make lawful } \\
\text { disposition of marijuana }\end{array}$ & DP & 3 & 2.11 & 2 & 1.14 & $1^{*}$ \\
\hline A33 & X2_318 & 30:4D-17 & $\begin{array}{l}\text { Medical Assistance and } \\
\text { Health Services Act: } \\
\text { Violations }\end{array}$ & $\begin{array}{l}\text { 2nd } \\
\text { Degree }\end{array}$ & 6 & 4.00 & 4 & 1.07 & $2 *$ \\
\hline A34 & X1_358 & $2 C: 29-3 b$ & $\begin{array}{l}\text { Hindering apprehension or } \\
\text { prosecution }\end{array}$ & $\begin{array}{l}\text { 2nd } \\
\text { Degree }\end{array}$ & 6 & 4.15 & 4 & 1.22 & $2 *$ \\
\hline
\end{tabular}




\begin{tabular}{|c|c|c|c|c|c|c|c|c|c|}
\hline A35 & X3_311 & $24: 21-22$ & $\begin{array}{l}\text { Fraud or misrepresentation by } \\
\text { registered manufacturers or } \\
\text { distributors }\end{array}$ & $\begin{array}{l}\text { 3rd } \\
\text { Degree }\end{array}$ & 5 & 4.09 & 4 & 1.23 & $1 *$ \\
\hline A36 & X3_396 & $\begin{array}{l}2 \mathrm{C}: 35- \\
5 \mathrm{~b}(1)\end{array}$ & $\begin{array}{l}\text { Manufacturing, distributing or } \\
\text { dispensing heroin or cocaine }\end{array}$ & $\begin{array}{l}1 \text { st } \\
\text { Degree }\end{array}$ & 7 & 4.99 & 5 & 1.27 & $2 *$ \\
\hline A37 & X2_398 & $\begin{array}{l}2 \mathrm{C}: 35- \\
5 \mathrm{~b}(6)\end{array}$ & $\begin{array}{l}\text { Manufacturing, distributing or } \\
\text { dispensing LSD }\end{array}$ & $\begin{array}{l}1 \text { st } \\
\text { Degree }\end{array}$ & 7 & 4.81 & 5 & 1.41 & $2 *$ \\
\hline A38 & X3_399 & $2 \mathrm{C}: 38-3$ & $\begin{array}{l}\text { Producing or possessing chemical } \\
\text { weapons, biological agents or } \\
\text { nuclear or radiological devices; } \\
\text { definitions }\end{array}$ & $\begin{array}{l}\text { 2nd } \\
\text { Degree }\end{array}$ & 6 & 3.78 & 4 & 2.11 & $2 *$ \\
\hline A39 & X2_308 & $19: 34-20$ & $\begin{array}{l}\text { Soliciting or procuring or assisting } \\
\text { unlawful registration and other } \\
\text { violations of election law }\end{array}$ & $\begin{array}{l}\text { 3rd } \\
\text { Degree }\end{array}$ & 5 & 2.89 & 3 & 1.20 & $2 *$ \\
\hline A 40 & X1_402 & $2 \mathrm{C}: 40-11$ & $\begin{array}{l}\text { Automatic safety shut-off device or } \\
\text { design feature to eliminate fire } \\
\text { hazard in event of tip over }\end{array}$ & PDP & 2 & 3.96 & 4 & 1.59 & $-2 *$ \\
\hline A41 & X2_403 & $2 \mathrm{C}: 40-12$ & Carbon monoxide limitations & PDP & 2 & 4.22 & 4 & 1.60 & $-2^{*}$ \\
\hline A42 & $\mathrm{X} 2 \_323$ & $\begin{array}{l}39: 4- \\
50 \mathrm{~g}(3)\end{array}$ & Driving while intoxicated & DP & 3 & 5.31 & 5 & 1.22 & $-2 *$ \\
\hline B1 & X0_369 & $2 C: 35-3$ & $\begin{array}{l}\text { Leader of narcotics trafficking } \\
\text { network }\end{array}$ & $\begin{array}{l}\text { 1st } \\
\text { Degree }\end{array}$ & 7 & 4.79 & 5 & 1.38 & $2 *$ \\
\hline B2 & X1_353 & $2 C: 22-2 b$ & Disposition of body parts & $\begin{array}{l}\text { 2nd } \\
\text { Degree }\end{array}$ & 6 & 4.67 & 5 & 1.13 & $1 *$ \\
\hline B3 & X2_383 & $2 \mathrm{C}: 20-31 \mathrm{~b}$ & $\begin{array}{l}\text { Wrongful access, disclosure of } \\
\text { information }\end{array}$ & $\begin{array}{l}\text { 2nd } \\
\text { Degree }\end{array}$ & 6 & 4.06 & 4 & 1.09 & $2 *$ \\
\hline B4 & X2_359 & $2 \mathrm{C}: 29-4$ & Compounding & $\begin{array}{l}\text { 3rd } \\
\text { Degree }\end{array}$ & 5 & 3.33 & 3 & 1.20 & $2 *$ \\
\hline B5 & X1_369 & $2 C: 35-4$ & $\begin{array}{l}\text { Maintaining or operating a } \\
\text { controlled dangerous substance } \\
\text { production facility }\end{array}$ & $\begin{array}{l}1 \text { st } \\
\text { Degree }\end{array}$ & 7 & 3.01 & 3 & 1.52 & $4 *$ \\
\hline B6 & X0_350 & $2 C: 21-25$ & $\begin{array}{l}\text { Money laundering; illegal } \\
\text { investment }\end{array}$ & $\begin{array}{l}1 \text { st } \\
\text { Degree }\end{array}$ & 7 & 4.22 & 5 & 1.60 & $2 *$ \\
\hline B7 & X0_351 & $2 C: 21-34 b$ & $\begin{array}{l}\text { Penalty for false representation in } \\
\text { government contract }\end{array}$ & $\begin{array}{l}\text { 2nd } \\
\text { Degree }\end{array}$ & 6 & 4.27 & 4 & 1.13 & $2 *$ \\
\hline B8 & X0_362 & $2 \mathrm{C}: 30-3$ & $\begin{array}{l}\text { Speculating or wagering on official } \\
\text { action or information }\end{array}$ & $\begin{array}{l}\text { 2nd } \\
\text { Degree }\end{array}$ & 6 & 3.25 & 4 & 1.64 & $2 *$ \\
\hline E1 & X0_324 & $4: 22-22$ & $\begin{array}{l}\text { Use or disposal of animals having } \\
\text { contagious diseases }\end{array}$ & $\begin{array}{l}\text { 4th } \\
\text { Degree }\end{array}$ & 4 & 5.62 & 6 & 1.16 & $-2 *$ \\
\hline E2 & X1_324 & $4: 22-25.3$ & $\begin{array}{l}\text { Prohibition of sale of dog or cat fur } \\
\text { or hair }\end{array}$ & $\begin{array}{l}\text { 4th } \\
\text { Degree }\end{array}$ & 4 & 2.93 & 3 & 1.63 & $1 *$ \\
\hline E3 & X3_315 & $\begin{array}{l}2 \mathrm{~A}: 156 \mathrm{~A}- \\
5\end{array}$ & $\begin{array}{l}\text { Possession, sale, distribution, } \\
\text { manufacture, or advertisement of } \\
\text { intercepting devices }\end{array}$ & $\begin{array}{l}\text { 3rd } \\
\text { Degree }\end{array}$ & 5 & 3.47 & 4 & 1.35 & $1 *$ \\
\hline E4 & X3_401 & $2 C: 39-4 a$ & $\begin{array}{l}\text { Possession of weapons for } \\
\text { unlawful purposes }\end{array}$ & $\begin{array}{l}\text { 2nd } \\
\text { Degree }\end{array}$ & 6 & 5.01 & 5 & 1.40 & $1^{*}$ \\
\hline
\end{tabular}




\begin{tabular}{|c|c|c|c|c|c|c|c|c|c|}
\hline E5 & X0_376 & $2 C: 39-5 c$ & Unlawful possession of weapons & $\begin{array}{l}\text { 3rd } \\
\text { Degree }\end{array}$ & 5 & 3.35 & 3 & 1.28 & $2 *$ \\
\hline E6 & X3_331 & $5: 12-113.1$ & $\begin{array}{l}\text { Use of device to obtain advantage } \\
\text { at casino game }\end{array}$ & $\begin{array}{l}\text { 2nd } \\
\text { Degree }\end{array}$ & 6 & 3.97 & 5 & 1.59 & $1 *$ \\
\hline E7 & X1_330 & $\begin{array}{l}5: 12- \\
113 \mathrm{c}(1)\end{array}$ & Swindling and cheating & $\begin{array}{l}\text { 2nd } \\
\text { Degree }\end{array}$ & 6 & 4.65 & 5 & 1.05 & $1 *$ \\
\hline E8 & X3_350 & $2 C: 21-22.1$ & Forgery and fraudulent practices & $\begin{array}{l}3 \text { rd } \\
\text { Degree }\end{array}$ & 5 & 2.78 & 3 & 1.55 & $2 *$ \\
\hline E9 & X3_378 & $2 \mathrm{C}: 40 \mathrm{~A}-5$ & $\begin{array}{l}\text { Additional penalty for attorneys; } \\
\text { grade of offense }\end{array}$ & $\begin{array}{l}\text { 3rd } \\
\text { Degree }\end{array}$ & 5 & 1.42 & 1 & 1.05 & $4 *$ \\
\hline E10 & X2_385 & 2C:21-19a & Criminal usury & $\begin{array}{l}\text { 2nd } \\
\text { Degree }\end{array}$ & 6 & 3.24 & 4 & 1.58 & $2 *$ \\
\hline E11 & X0_395 & $\begin{array}{l}2 \mathrm{C}: 35- \\
5 \mathrm{~b}(10)(\mathrm{a})\end{array}$ & $\begin{array}{l}\text { Manufacturing, distributing or } \\
\text { dispensing marijuana }\end{array}$ & $\begin{array}{l}1 \text { st } \\
\text { Degree }\end{array}$ & 7 & 4.46 & 5 & 1.71 & $2 *$ \\
\hline E12 & X1_397 & $\begin{array}{l}2 \mathrm{C}: 35- \\
5 \mathrm{~b}(5)\end{array}$ & $\begin{array}{l}\text { Manufacturing, distributing or } \\
\text { dispensing schedule I or II drugs }\end{array}$ & $\begin{array}{l}\text { 3rd } \\
\text { Degree }\end{array}$ & 5 & 3.30 & 3 & 1.35 & $2^{*}$ \\
\hline E13 & X4_335 & $2 C: 35-13$ & Obtaining by fraud & $\begin{array}{l}\text { 3rd } \\
\text { Degree }\end{array}$ & 5 & 3.59 & 4 & 1.12 & $1 *$ \\
\hline E14 & X2_349 & $2 \mathrm{C}: 21-2.1 \mathrm{a}$ & $\begin{array}{l}\text { Offenses involving false } \\
\text { government documents }\end{array}$ & $\begin{array}{l}\text { 2nd } \\
\text { Degree }\end{array}$ & 6 & 4.11 & 4 & 1.08 & $2 *$ \\
\hline E15 & X3_349 & 2C:21-2.1b & $\begin{array}{l}\text { Offenses Involving False } \\
\text { Government Documents }\end{array}$ & $\begin{array}{l}\text { 2nd } \\
\text { Degree }\end{array}$ & 6 & 3.47 & 4 & 1.81 & $2 *$ \\
\hline E16 & X3_371 & $2 \mathrm{C}: 36-4$ & Advertising to promote sale & $\begin{array}{l}\text { 4th } \\
\text { Degree }\end{array}$ & 4 & 2.08 & 1 & 1.38 & $3 *$ \\
\hline E17 & X4_423 & $\begin{array}{l}2 \mathrm{C}: 35- \\
10 \mathrm{a}(3)\end{array}$ & $\begin{array}{l}\text { Possession, use or being under the } \\
\text { influence, or failure to make lawful } \\
\text { disposition of marijuana }\end{array}$ & $\begin{array}{l}\text { 4th } \\
\text { Degree }\end{array}$ & 4 & 2.98 & 3 & 1.44 & $1 *$ \\
\hline $\mathrm{F} 1$ & X0_311 & $24: 6 \mathrm{~B}-29 \mathrm{~b}$ & $\begin{array}{l}\text { Violations applicable to } \\
\text { prescription drug distribution }\end{array}$ & $\begin{array}{l}1 \text { st } \\
\text { Degree }\end{array}$ & 7 & 5.36 & 6 & 1.53 & $1 *$ \\
\hline $\mathrm{F} 2$ & X0_327 & $45: 6-24$ & Falsifying dental application & $\begin{array}{l}\text { 3rd } \\
\text { Degree }\end{array}$ & 5 & 3.81 & 4 & 1.24 & $1 *$ \\
\hline $\mathrm{F} 3$ & X0_353 & $2 \mathrm{C}: 22-1 \mathrm{a}$ & $\begin{array}{l}\text { Disturbing, desecrating human } \\
\text { remains }\end{array}$ & $\begin{array}{l}\text { 2nd } \\
\text { Degree }\end{array}$ & 6 & 4.53 & 5 & 1.18 & $1 *$ \\
\hline $\mathrm{F} 4$ & X0_366 & $2 C: 33-3 c$ & False public alarms & \begin{tabular}{|l} 
st \\
Degree
\end{tabular} & 7 & 5.87 & 6 & 1.15 & $1 *$ \\
\hline F5 & X0_367 & $2 \mathrm{C}: 34-2 b$ & Obscenity for persons over 18 & $\begin{array}{l}\text { 4th } \\
\text { Degree }\end{array}$ & 4 & 1.33 & 1 & 0.93 & $3 *$ \\
\hline F6 & X0_397 & $\begin{array}{l}2 \mathrm{C}: 35- \\
5 \mathrm{~b}(9)(\mathrm{a})\end{array}$ & $\begin{array}{l}\text { Manufacturing, distributing or } \\
\text { dispensing methamphetamine }\end{array}$ & $\begin{array}{l}\text { 2nd } \\
\text { Degree }\end{array}$ & 6 & 4.37 & 4 & 1.32 & $2 *$ \\
\hline F7 & X0_400 & $2 C: 39-4 a$ & $\begin{array}{l}\text { Possession of weapons for } \\
\text { unlawful purposes }\end{array}$ & $\begin{array}{l}\text { 2nd } \\
\text { Degree }\end{array}$ & 6 & 4.97 & 5 & 1.45 & $1 *$ \\
\hline F8 & X0_403 & $2 \mathrm{C}: 40 \mathrm{~A}-1$ & Employer requiring lie detector test & DP & 3 & 2.06 & 1 & 1.37 & $2 *$ \\
\hline F9 & X1_321 & $39: 3-40 c$ & $\begin{array}{l}\text { Penalties for driving while license } \\
\text { suspended }\end{array}$ & DP & 3 & 4.00 & 4 & 1.13 & $-1 *$ \\
\hline F10 & X1_339 & 2C:11-6 & Aiding suicide & 2 nd & 6 & 4.74 & 6 & 2.28 & 0 \\
\hline
\end{tabular}




\begin{tabular}{|c|c|c|c|c|c|c|c|c|c|}
\hline & & & & Degree & & & & & \\
\hline F11 & X1_343 & $\begin{array}{l}2 \mathrm{C}: 17- \\
3 \mathrm{~b}(4)\end{array}$ & Criminal mischief & $\begin{array}{l}\text { 4th } \\
\text { Degree }\end{array}$ & 4 & 5.65 & 5 & 1.23 & $-1 *$ \\
\hline F12 & X1_374 & $2 \mathrm{C}: 38-4 \mathrm{~b}$ & $\begin{array}{l}\text { Hindering apprehension or } \\
\text { prosecution for terrorism }\end{array}$ & $\begin{array}{l}\text { 1st } \\
\text { Degree }\end{array}$ & 7 & 5.76 & 6 & 1.29 & $1 *$ \\
\hline F13 & X1_375 & $2 C: 39-13$ & Unlawful use of body vests & $\begin{array}{l}\text { 2nd } \\
\text { Degree }\end{array}$ & 6 & 5.77 & 6 & 1.57 & 0 \\
\hline F14 & X1_377 & $2 C: 40-3 b$ & Hazing & $\begin{array}{l}\text { 4th } \\
\text { Degree }\end{array}$ & 4 & 5.41 & 5 & 0.95 & $-1 *$ \\
\hline F15 & X2_340 & 2C:11A-1 & Cloning of human being & $\begin{array}{l}1 \text { st } \\
\text { Degree }\end{array}$ & 7 & 3.27 & 3 & 2.25 & $4 *$ \\
\hline F16 & X2_343 & $2 \mathrm{C}: 17-1 \mathrm{~g}$ & Arson of a place of worship & $\begin{array}{l}\text { 1st } \\
\text { Degree }\end{array}$ & 7 & 5.61 & 6 & 1.08 & $1 *$ \\
\hline F17 & X2_348 & $2 \mathrm{C}: 21-17.2$ & $\begin{array}{l}\text { Use of personal identifying } \\
\text { information of another }\end{array}$ & $\begin{array}{l}\text { 2nd } \\
\text { Degree }\end{array}$ & 6 & 3.89 & 4 & 1.11 & $2 *$ \\
\hline F18 & X2_360 & $2 C: 29-6 a$ & Implements for escape & $\begin{array}{l}\text { 2nd } \\
\text { Degree }\end{array}$ & 6 & 4.32 & 4 & 1.35 & $2 *$ \\
\hline F19 & X2_368 & $\begin{array}{l}2 \mathrm{C}: 34- \\
3 \mathrm{c}(1)\end{array}$ & Obscenity for persons under 18 & $\begin{array}{l}\text { 3rd } \\
\text { Degree }\end{array}$ & 5 & 2.76 & 3 & 1.22 & $2 *$ \\
\hline F20 & X2_376 & $2 C: 39-4 d$ & $\begin{array}{l}\text { Possession of weapons for } \\
\text { unlawful purposes }\end{array}$ & $\begin{array}{l}\text { 3rd } \\
\text { Degree }\end{array}$ & 5 & 3.43 & 4 & 1.32 & $1 *$ \\
\hline F21 & X2_378 & $2 \mathrm{C}: 40 \mathrm{~A}-2$ & $\begin{array}{l}\text { Violation of contract to pay } \\
\text { employees }\end{array}$ & DP & 3 & 3.79 & 4 & 1.33 & $-1 *$ \\
\hline F22 & X2_382 & $2 C: 20-17$ & $\begin{array}{l}\text { Use of juvenile in theft of } \\
\text { automobiles }\end{array}$ & $\begin{array}{l}\text { 2nd } \\
\text { Degree }\end{array}$ & 6 & 4.81 & 5 & 0.89 & $1 *$ \\
\hline F23 & X2_392 & 2C:29-3.1 & $\begin{array}{l}\text { Animal owned, used by law } \\
\text { enforcement agency, search and } \\
\text { rescue dog, infliction of harm } \\
\text { upon, interference with officer }\end{array}$ & DP & 3 & 3.53 & 3.5 & 1.30 & -0.5 \\
\hline F24 & X3_341 & $2 \mathrm{C}: 13-1 \mathrm{~b}$ & Kidnapping & $\begin{array}{l}\text { 1st } \\
\text { Degree }\end{array}$ & 7 & 5.50 & 6 & 1.21 & $1 *$ \\
\hline $\mathrm{F} 25$ & X3_352 & $2 \mathrm{C}: 21-4.3 \mathrm{c}$ & Health care claims fraud & $\begin{array}{l}\text { 2nd } \\
\text { Degree }\end{array}$ & 6 & 4.28 & 4 & 0.78 & $2 *$ \\
\hline F26 & X3_369 & $2 C: 35-28$ & $\begin{array}{l}\text { Unlawful possession of precursors } \\
\text { manufacturing methamphetamine. }\end{array}$ & $\begin{array}{l}\text { 2nd } \\
\text { Degree }\end{array}$ & 6 & 4.32 & 5 & 1.40 & $1 *$ \\
\hline F27 & X3_372 & $2 C: 37-3$ & Possession of gambling records & $\begin{array}{l}\text { 3rd } \\
\text { Degree }\end{array}$ & 5 & 3.41 & 4 & 1.26 & $1 *$ \\
\hline F28 & X3_384 & $2 C: 21-11$ & Rigging publicly exhibited contest & $\begin{array}{l}\text { 2nd } \\
\text { Degree }\end{array}$ & 6 & 4.61 & 5 & 1.13 & $1 *$ \\
\hline F29 & X4_422 & $\begin{array}{l}2 \mathrm{C}: 35- \\
10 \mathrm{a}(2)\end{array}$ & $\begin{array}{l}\text { Possession, use or being under the } \\
\text { influence, or failure to make lawful } \\
\text { disposition of a schedule V drug }\end{array}$ & $\begin{array}{l}4 \text { th } \\
\text { Degree }\end{array}$ & 4 & 2.60 & 2 & 1.19 & $2 *$ \\
\hline F30 & X4_426 & $2 \mathrm{C}: 35-10 \mathrm{~b}$ & $\begin{array}{l}\text { Possession, use or being under the } \\
\text { influence, or failure to make lawful } \\
\text { disposition of a controlled } \\
\text { dangerous substance }\end{array}$ & DP & 3 & 1.78 & 1 & 1.05 & $2 *$ \\
\hline
\end{tabular}




\begin{tabular}{|l|l|l|l|l|l|l|l|l|l|} 
F31 & X4_427 & 2C:35-10c & $\begin{array}{l}\text { Possession of a dangerous } \\
\text { controlled substance }\end{array}$ & DP & 3 & 1.70 & 1 & 1.05 & $2 *$ \\
\hline
\end{tabular}

Table 2: Broad Offenses

\begin{tabular}{|c|c|c|c|c|c|c|c|c|c|}
\hline $\begin{array}{l}\text { Reference } \\
\text { Number }\end{array}$ & Title & Section & NJ Grade & ID & Type of Conduct & Mean & Median & SD & Difference $^{333}$ \\
\hline D1 & \multirow{2}{*}{$\begin{array}{l}\text { Sex offender } \\
\text { participating } \\
\text { in a youth } \\
\text { serving } \\
\text { organization }\end{array}$} & \multirow[t]{2}{*}{$2 C: 7-23 a-b$} & \multirow[t]{2}{*}{$\begin{array}{l}\text { 3rd } \\
\text { Degree }\end{array}$} & X4_342 & Least egregious & 2.27 & 1 & 1.86 & \multirow[t]{2}{*}{$5 *$} \\
\hline D2 & & & & X4_343 & Most egregious & 5.85 & 6 & 1.86 & \\
\hline A14, D3 & \multirow{2}{*}{\begin{tabular}{|l} 
Fighting or \\
baiting \\
animals or \\
creatures and \\
related \\
offenses
\end{tabular}} & \multirow[t]{2}{*}{$4: 22-24$} & \multirow[t]{2}{*}{$\begin{array}{l}\text { 3rd } \\
\text { Degree }\end{array}$} & X4_306 & Least egregious & 2.77 & 3 & 1.43 & \multirow[t]{2}{*}{$2 *$} \\
\hline D4 & & & & X4_307 & Most egregious & 4.82 & 5 & 1.35 & \\
\hline D5 & \multirow[t]{2}{*}{$\begin{array}{l}\text { Violations of } \\
\text { regulations } \\
\text { for contracts }\end{array}$} & \multirow[t]{2}{*}{$52: 34-18$} & \multirow[t]{2}{*}{$\begin{array}{l}\text { 4th } \\
\text { Degree }\end{array}$} & X4_374 & Least egregious & 2.50 & 2 & 1.58 & \multirow[t]{2}{*}{$3 *$} \\
\hline D6 & & & & X4_375 & Most egregious & 4.53 & 5 & 1.49 & \\
\hline A18, D7 & \multirow{2}{*}{$\begin{array}{l}\text { Failure to } \\
\text { file returns } \\
\text { or reports } \\
\text { with intent to } \\
\text { defraud or to } \\
\text { evade, avoid } \\
\text { or not make } \\
\text { timely } \\
\text { payments }\end{array}$} & \multirow{2}{*}{ 54:52-8 } & \multirow[t]{2}{*}{$\begin{array}{l}\text { 3rd } \\
\text { Degree }\end{array}$} & X4_324 & Least egregious & 2.63 & 3 & 1.21 & \multirow[t]{2}{*}{$2 *$} \\
\hline D8 & & & & X4_325 & Most egregious & 4.55 & 5 & 1.17 & \\
\hline D9 & \multirow{2}{*}{$\begin{array}{l}\text { Soliciting or } \\
\text { providing } \\
\text { material } \\
\text { support or } \\
\text { resources for } \\
\text { terrorism }\end{array}$} & \multirow{2}{*}{$2 \mathrm{C}: 38-5 \mathrm{~b}$} & \multirow[t]{2}{*}{$\begin{array}{l}\text { 2nd } \\
\text { Degree }\end{array}$} & X1_399 & Least egregious & 4.30 & 5 & 2.57 & \multirow[t]{2}{*}{1} \\
\hline D10 & & & & X1_404 & Most egregious & 5.87 & 6 & 1.63 & \\
\hline D11 & $\begin{array}{l}\text { Water } \\
\text { Supply } \\
\text { Management } \\
\text { : Violations; }\end{array}$ & 58:1A-16 & $\begin{array}{l}\text { 3rd } \\
\text { Degree }\end{array}$ & X4_304 & Least egregious & 2.26 & 2 & 1.38 & $3 *$ \\
\hline
\end{tabular}

${ }^{333}$ An asterisk indicates statistical significance of the difference between the sampled median of each of the two scenarios at the 0.05 level based upon the method described supra at note 128. If the t-test is used instead as a measure of statistical significance of the difference between the sample means of the two scenarios, the following additional question pairs exhibit statistical significance X1_399 / X1_404; X4_419 / X4_420. 


\begin{tabular}{|c|c|c|c|c|c|c|c|c|c|}
\hline D12 & $\begin{array}{l}\text { commissione } \\
\text { r actions; } \\
\text { civil } \\
\text { administrativ } \\
\text { e penalties; } \\
\text { criminal } \\
\text { penalties }\end{array}$ & & & X4_305 & Most egregious & 5.05 & 5 & 1.30 & \\
\hline D13 & \multirow{2}{*}{$\begin{array}{l}\text { Violation of } \\
\text { embalmer } \\
\text { and funeral } \\
\text { director } \\
\text { regulations }\end{array}$} & \multirow[t]{2}{*}{$45: 7-65.5$} & \multirow{2}{*}{$\begin{array}{l}\text { 4th } \\
\text { Degree }\end{array}$} & X4_318 & Least egregious & 1.78 & 1 & 1.28 & \multirow[t]{2}{*}{$4 *$} \\
\hline D14 & & & & X4_319 & Most egregious & 4.89 & 5 & 1.33 & \\
\hline D15 & \multirow{2}{*}{$\begin{array}{l}\text { Possession } \\
\text { of certain } \\
\text { prescription } \\
\text { drugs }\end{array}$} & \multirow[t]{2}{*}{$2 C: 35-24$} & \multirow[t]{2}{*}{ DP } & X4_336 & Least egregious & 1.68 & 1 & 1.31 & \multirow[t]{2}{*}{$2 *$} \\
\hline D16 & & & & X4_337 & Most egregious & 3.32 & 3 & 1.34 & \\
\hline D17 & \multirow{2}{*}{$\begin{array}{l}\text { Impounding } \\
\text { or taking } \\
\text { dogs or other } \\
\text { animals into } \\
\text { custody; } \\
\text { grounds; } \\
\text { notice; } \\
\text { destruction } \\
\text { or adoption; } \\
\text { sale or } \\
\text { availability } \\
\text { for } \\
\text { experimentat } \\
\text { ion } \\
\text { prohibited; } \\
\text { penalty; } \\
\text { reporting of } \\
\text { rabid } \\
\text { animals } \\
\end{array}$} & \multirow[t]{2}{*}{$4: 19-15.16$} & \multirow[t]{2}{*}{$\begin{array}{l}\text { 4th } \\
\text { Degree }\end{array}$} & X4_322 & Least egregious & 3.47 & 3.5 & 1.61 & \multirow[t]{2}{*}{$1.5^{*}$} \\
\hline D18 & & & & X4_323 & Most egregious & 5.19 & 5 & 1.57 & \\
\hline D19 & \multirow{2}{*}{\begin{tabular}{|l|} 
Violations \\
applicable to \\
prescription \\
drug \\
distribution \\
\end{tabular}} & \multirow[t]{2}{*}{$24: 6 \mathrm{~B}-29 \mathrm{a}$} & \multirow{2}{*}{$\begin{array}{l}\text { 3rd } \\
\text { Degree }\end{array}$} & X4_356 & Least egregious & 1.54 & 1 & 0.96 & \multirow[t]{2}{*}{$4 *$} \\
\hline D20 & & & & X4_357 & Most egregious & 4.63 & 5 & 1.32 & \\
\hline D21 & \multirow{2}{*}{$\begin{array}{l}\text { Strict } \\
\text { Liability for } \\
\text { Drug- } \\
\text { Induced } \\
\text { Deaths }\end{array}$} & \multirow[t]{2}{*}{$2 C: 35-9$} & \multirow[t]{2}{*}{ 1st Degree } & X4_419 & Least egregious & 5.19 & 6 & 1.69 & \multirow[t]{2}{*}{0} \\
\hline D22 & & & & X4_420 & Most egregious & 5.55 & 6 & 1.47 & \\
\hline
\end{tabular}




\section{Appendix G: The Survey Instrument and Questions}

\section{Initiating the Survey}

Subjects participating in the study via Amazon's Mechanical Turk system were able to locate it through a keyword search or via Mechanical Turk's online listing of available tasks. Upon finding the study, subjects were presented with an informational screen giving a brief overview of the study, and could choose to view the instructions without committing to taking it. The initial screen appeared as follows ${ }^{334}$ :

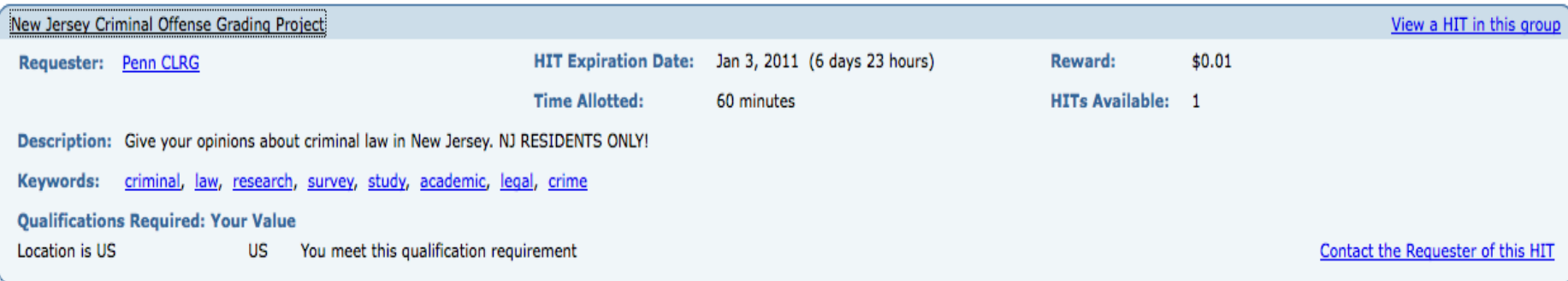

Initially, the Mechanical Turk interface was designed such that the survey appeared in a frame in the same window as the Mechanical Turk page. The initial page of the survey appeared as follows:

334 The reward, time allotted, and expiration date are different in this screenshot than in the actual survey instrument. In the actual survey, the reward was $\$ 2.00, \$ 3.00$, or $\$ 5.00$, the expiration date varied throughout the survey, and the time allotted was 3 hours. 


\section{\%enn Law}

UNIVERSITY OF PENNSYLVANIA LAW SCHOOL

CRIMINAL LAW RESEARCH GROUP

Does the punishment fit the crime? The state of New Jersey really wants to know your views on crime in our state. In 127 questions you can help shape the criminal law.

Here is how it works:

--You will read about a crime that is on the books in New Jersey.

--You will tell us how serious the crime is, 1-7, with 7 being the most serious.

--To help you decide we will give you some examples - "milestone cases." For example, a 7 would be equal

to murder. And something that you felt deserved a 1 would be equal to a petty offense.

Justice has to be for everyone so we are going to ask a few demographic questions to make sure we are getting lots of views.

THERE IS NO TIME LIMIT

THERE ARE NO RIGHT AND WRONG ANSWERS

YOUR INPUT MATTERS SO PLEASE TAKE THE 30-45 MINUTES TO CAREFULLY TAKE THE SURVEY. THANKS

ELIGIBILITY:

IF YOU HAVE TAKEN THIS SURVEY ALREADY UNDER A DIFFERENT HIT, DO NOT TAKE IT AGAIN. YOU WILL NOT GET PAID IF YOU HAVE ALREADY TAKEN THE SURVEY.

This study is open to NEW JERSEY RESIDENTS ONLY. You will be asked to verify your New Jersey residence. Also, we will use your computer's IP address to verify that you are taking the survey in New Jersey. If your IP address indicates that you are not in New Jersey, your HIT will be rejected and you will not be paid.

You must complete the survey in order to be paid. If you stop taking the survey before you answer all the questions, you will not be paid.

You must be 18 years of age or older to take the survey.

To begin the survey, first accept the HIT, and then click "Next" below.

After working through the survey, which is described further below, the survey instrument automatically communicated with the Mechanical Turk website to facilitate payment.

Volunteer respondents throughout the survey were presented with the above introduction (by default in an existing window or tab) immediately after following a link to the survey. The survey then progressed as described further below.

Because of technical difficulties, the Mechanical Turk interface was changed slightly after the survey was underway, although the content of the survey instrument remained the same. In the modified design, Mechanical Turk workers saw the following initial screen, which appeared in a frame in the Mechanical Turk page: 


\title{
New Jersey Criminal Offense Grading Study
}

\author{
UNIVERSITY OF PENNSYLVANIA LAW SCHOOL
}

CRIMINAL LAW RESEARCH GROUP

Does the punishment fit the crime? The state of New Jersey really wants to know your views on crime in our state. In 127 questions you can help shape the criminal law.

Here is how it works:

--You will read about a crime that is on the books in New Jersey.

--You will tell us how serious the crime is, 1-7, with 7 being the most serious.

--To help you decide we will give you some examples -- "milestone cases." For example, a 7 would be equal to murder. And something that you felt deserved a 1

would be equal to a petty offense.

Justice has to be for everyone so we are going to ask a few demographic questions to make sure we are getting lots of views.

THERE IS NO TIME LIMIT

THERE ARE NO RIGHT AND WRONG ANSWERS

YOUR INPUT MATTERS SO PLEASE TAKE THE 30-45 MINUTES TO CAREFULLY TAKE THE SURVEY. THANKS

ELIGIBILITY:

IF YOU HAVE TAKEN THIS SURVEY ALREADY UNDER A DIFFERENT HIT, DO NOT TAKE IT AGAIN. YOU WILL NOT GET PAID IF YOU HAVE ALREADY TAKEN THE SURVEY.

This study is open to NEW JERSEY RESIDENTS ONLY. You will be asked to verify your New Jersey residence. Also, we will use your computer's IP address to verify that you are taking the survey in New Jersey. If your IP address indicates that you are not in New Jersey, your HIT will be rejected and you will not be paid.

You must complete the survey in order to be paid. If you stop taking the survey before you answer all the questions, you will not be paid.

You must be 18 years of age or older to take the survey.

\section{INSTRUCTIONS:}

Click on the link below to open the survey. The survey should open in a new window or tab. (If the survey does not open in a new window or tab, then navigate back to this page and open the survey in a new window or tab manually. The survey will not navigate back to this page when it completes).

After you have answered all of the survey questions, you will be given a code to enter in the box below. Of course, you must accept the HIT before submitting the completion code.

$\underline{\text { Start the Survey! }}$

After you have completed the survey, enter the completion code here and submit your HIT

In the modified design, the respondent would initiate the survey by clicking on the "Start the Survey!" link, which would open the survey in a new window or tab. After completing the survey, the respondent would be provided with a completion code to enter into the text box for submission.

\section{Verifying New Jersey Residence}

After entering the survey, respondents were reminded that only New Jersey residents were eligible to participate in the survey: 
This study is for New Jersey residents only!

This study is open only to residents of the State of New Jersey, in the United States. It is very important to our data collection effort that we sample New Jersey residents only. If your computer's IP address indicates that you are located outside New Jersey, your responses will not be counted, your HIT will be rejected, and you will not be paid

If you are not from New Jersey, please click "Return HIT" in Mechanical Turk. We thank you for your time. If you are from New Jersey, please hit Next to get started.

Thank you

\section{Test Offenses}

Respondents were provided the following explanation of how to evaluate the test offenses relative to the milestone table:

Please study the "Milestone Offenses" list below carefully. You will be given a series of offenses and asked to determine, for each, which "level" the given test offense is most like.

We are not asking what length of sentence you think should be imposed for each offense. We are asking you only to identify the Milestone Offenses that are most like the level of seriousness of each of the offenses you will be shown.

Below is an illustration of what each question will look like. On the left is the Milestone Offenses list; it will remain the same throughout the survey. On the right is the test offense; this will change for each question. Please familiarize yourself with this setup, and then answer the question below.

\begin{tabular}{|c|c|c|}
\hline & Milestone Offenses & Test Offense \\
\hline Level 7 & Aggravated Murder: Intentionally killing a 10 year old child. & \multirow{7}{*}{$\begin{array}{l}\text { A description of the } \\
\text { test offense will be } \\
\text { shown here. }\end{array}$} \\
\hline Level 6 & Murder: Intentionally killing an adult. & \\
\hline Level 5 & $\begin{array}{l}\text { Aggravated Assault - Serious Bodily Injury: Beating a person to intentionally cause paralysis. } \\
\text { Manslaughter: An owner of dangerous pit bulls causing the death of a neighbor's child by refusing } \\
\text { to fix the broken lock on their cage. } \\
\text { Sexual Assault: Forcibly raping an adult. } \\
\text { Aggravated Theft: Stealing } \$ 5 \text { million. }\end{array}$ & \\
\hline Level 4 & $\begin{array}{l}\text { Aggravated Assault -Bodily Injury: Intentionally slashing another person's shoulder with a knife. } \\
\text { Criminal Mischief- } \$ 25,000: \text { Intentionally causing } \$ 25,000 \text { of property damage. } \\
\text { Theft - } \$ 25,000 \text { : Stealing } \$ 25,000 \text {. }\end{array}$ & \\
\hline Level 3 & $\begin{array}{l}\text { Stalking: Intentionally causing another person emotional distress. } \\
\text { Criminal Mischief - } \$ 500: \text { Causing } \$ 500 \text { in property damage. } \\
\text { Theft - } \$ 500 \text { : Stealing } \$ 500 \text {. }\end{array}$ & \\
\hline Level 2 & $\begin{array}{l}\text { Simple Assault: Intentionally giving another person a black eye. } \\
\text { Lewdness: Running naked in a public place. } \\
\text { Criminal Mischief: Causing } \$ 40 \text { in property damage. } \\
\text { Petty Theft: Stealing } \$ 40 \text {. }\end{array}$ & \\
\hline Level 1 & $\begin{array}{l}\text { Petty Assault: Fighting with another by mutual consent } \\
\text { Harassment: Intentionally annoying a person by making anonymous phone calls to them at } 2 \text { am. }\end{array}$ & \\
\hline
\end{tabular}

Answering the Questions

Suppose that the test offense above was "Reckless Driving," and that you judged this offense to be as serious as the Milestone Offenses listed in Level 4. In that case, you would select "Level 4" below, and then click "Next" to proceed with the survey.

Each test offense appeared in a format similar to the sample test offense above. For example, the following figure shows one of the actual test offense questions: 


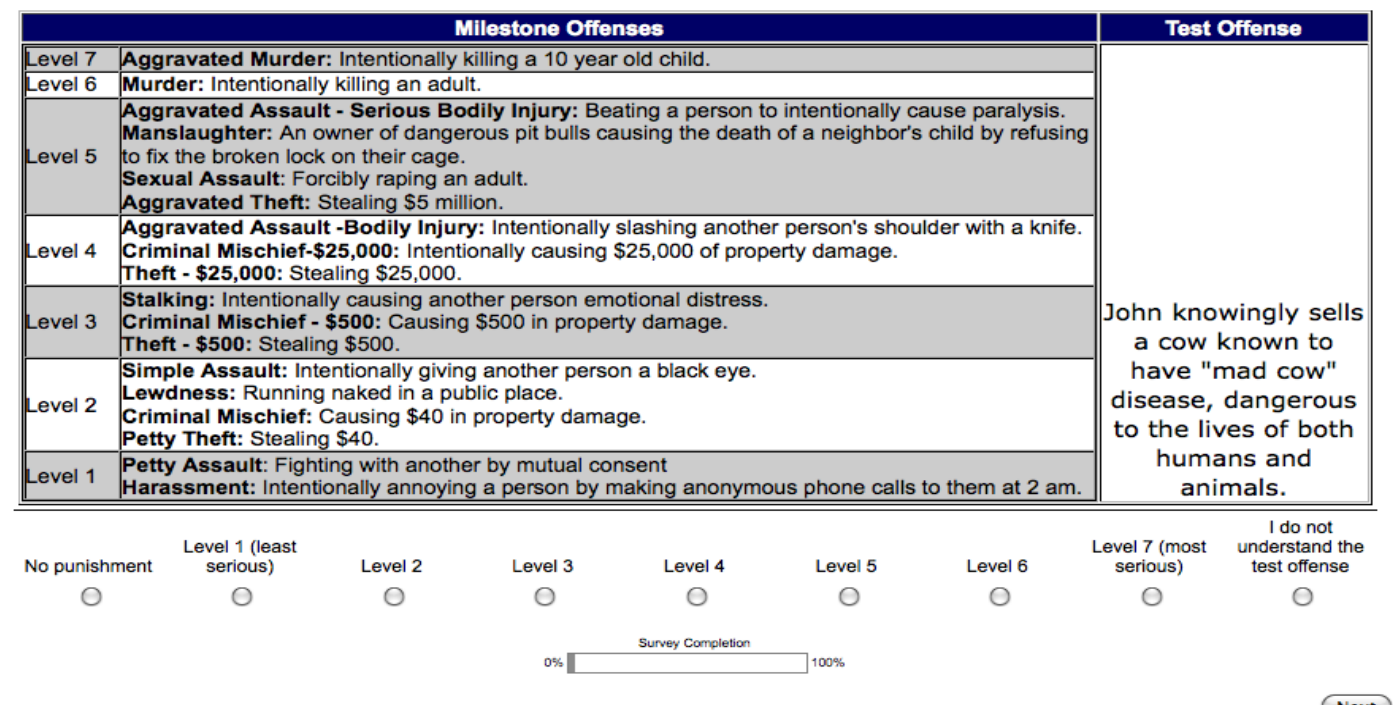

Each test offense question appeared in a random order, with the exception of two control questions. The control questions contained a hypothetical offense which exactly matched one of the milestone offenses. Only responses were included where the respondent either answered both control questions correctly or missed one control question by only one degree. The text of the control questions was "John intentionally causes $\$ 25,000$ in property damage" and "John intentionally gives another person a black eye." The two control questions appeared near the end of the survey, one at 11 questions before the end of the survey, and the other at 30 questions before the end of the survey.

\section{Demographics}

In addition, the survey asked the following demographic questions of respondents. The demographic questions were asked throughout the survey in order to interrupt the flow of test offense questions.

"What is your gender?"

Choices: "Male" and "Female."

"What is your age?"

Choices: "Under 18 years", "18 to 24 years", "25 to 34 years", "35 to 44 years", "45 to 54 years", "55 to 64 years", "65 to 74 years", "75 to 84 years", "85 years and over."

"What is your race?"

Choices: "White/Caucasian", "African American", "Hispanic", "Asian", "Native American", "Pacific Islander", "Other", "Prefer Not to Answer."

"What is the highest level of education you have completed"? 
Choices: "Less than High School", "High School/GED", "Some College", "2-year College Degree", "4-year College Degree", "Master's Degree", "Doctoral Degree",

"Professional Degree (JD, MD)."

"What is your combined annual household income?"

Choices: "under \$20,000", "20,000-29,999", "30,000-39,999", "40,000-49,999", "50,000-59,999", "60,000-69,999", "70,000-79,999", "80,000-89,999", "90,000-99,999", "100,000-109,000", "110,000-119,999", "120,000-129,999", "130,000-139,999", "140,000-149,999", "150,000+", "I prefer not to answer."

"Please indicate your marital status:"

Choices: "Single", "Married", "Separated", "Divorced", "Widowed."

"Please indicate the description that best describes your political views:"

Choices: "Very Liberal", "Somewhat Liberal", "Moderate", "Somewhat

Conservative," "Very Conservative."

"Please select the county in which you reside:"

Choices: List of New Jersey counties, in alphabetical order.

"In which New Jersey city or town do you reside?"

Respondents entered their answer in a text box.

The following is an example demographic question:

Please indicate the description that best describes your political views:

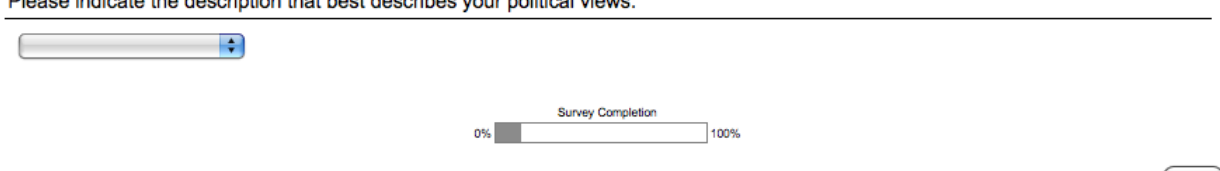

\section{Concluding the Survey}

In the initial Mechanical Turk survey design, respondents were presented with the following message before their results were transmitted to Mechanical Turk:

\footnotetext{
Thank you for completing our survey. Please click the button below to submit your results to Mechanical Turk. After doing this, we will receive your results and will approve payment as soon as possible. Again, we appreciate your time, and thank you for participating!
}

Submit to Mechanical Turk

In the second version of the Mechanical Turk survey, the respondent was presented with the following message, and a unique completion code: 
Thank you for completing the survey. Please enter the following code into Mechanical Turk and hit submit:

Volunteer respondents were presented with the following message:

Thank you for your time in completing the survey. Your responses have been recorded. Your participation will help us to improve criminal justice in New Jersey.

- Penn Criminal Law Research Group

\section{Text of the Test Offenses as Presented in the Survey Instrument:}

\begin{tabular}{|c|c|}
\hline ID & Text of Question \\
\hline X4_342 & $\begin{array}{l}\text { John, a } 30 \text { year old man who had been convicted of a sex crime when he was } 18 \text { for } \\
\text { having intercourse with his } 15 \text { year old girlfriend, now serves as a coach for his son's } \\
\text { basketball team. }\end{array}$ \\
\hline X4_304 & $\begin{array}{l}\text { John, an industrial farmer who diverts water for irrigation, knowingly files his renewal } \\
\text { application to continue diverting water after the renewal deadline. }\end{array}$ \\
\hline X1_399 & $\begin{array}{l}\text { A group of friends holds a fundraiser to raise } \$ 1 \text { million to help a nonprofit, which they } \\
\text { believe works to increase understanding among faiths, but which actually supports Al } \\
\text { Qaeda's terrorist training camps in Pakistan. }\end{array}$ \\
\hline X4_318 & $\begin{array}{l}\text { John, a funeral home director, overhears a hospital nurse telling a patient's family } \\
\text { member that the patient is about to die. John then approaches the family member and } \\
\text { hands him a business card for his funeral home while standing in the hospital corridor. }\end{array}$ \\
\hline X4_356 & $\begin{array}{l}\text { John knowingly creates a fake label for his prescription hair loss medication bottle } \\
\text { because he doesn't want others to know he is taking the medication. }\end{array}$ \\
\hline X4_374 & $\begin{array}{l}\text { John, the Superintendent of State Prisons, purchases products for the prisons without the } \\
\text { EPA's Energy Star Label. John makes these purchases even though there are similarly } \\
\text { priced products with the Energy Star Label. }\end{array}$ \\
\hline X4_322 & $\begin{array}{l}\text { John, a county animal control officer, knowingly makes a dog from the pound available } \\
\text { to an owner of a shampoo company looking to see how the shampoo works on fur. }\end{array}$ \\
\hline X4_306 & John knowingly watches a dog fight. \\
\hline X4_324 & $\begin{array}{l}\text { John, a waiter, with the intent to avoid paying some taxes, does not declare his cash tips, } \\
\text { which total } \$ 500 \text { for the year. }\end{array}$ \\
\hline X4_336 & $\begin{array}{l}\text { John combines a } 2 \text {-week supply of several prescription medications into a singe bottle } \\
\text { while packing for an overseas trip. }\end{array}$ \\
\hline X4_419 & $\begin{array}{l}\text { John sells one dose of LSD (a hallucinogenic drug) to another person. While taking the } \\
\text { drug, that person has a "bad trip" and kills himself. }\end{array}$ \\
\hline X4_343 & $\begin{array}{l}\text { John, who has multiple convictions for raping } 10 \text { year old children, takes a job as a } \\
\text { teacher for a fourth grade class. }\end{array}$ \\
\hline X4_305 & A water supply company purposely provides sub-standard drinking water to residents. \\
\hline
\end{tabular}




\begin{tabular}{|c|c|}
\hline X1_404 & $\begin{array}{l}\text { John and a group of his friends, who don't like American capitalism, hold a community } \\
\text { fundraiser. This group sends the proceeds from this fundraiser to Al Qaeda's terrorist } \\
\text { training camps in Pakistan. }\end{array}$ \\
\hline X4_319 & $\begin{array}{l}\text { John, an embalmer, knowingly injects arsenic into the body of a person who has died } \\
\text { suddenly under suspicious circumstances. Arsenic is both a prohibited embalming } \\
\text { substance and can prevent detection of poisoning. }\end{array}$ \\
\hline X4_357 & $\begin{array}{l}\text { John knowingly brings into the state } 5000 \text { prescription painkiller pills that he does not } \\
\text { have a prescription for, with the intent of selling those pills to other people who also do } \\
\text { not have prescriptions for them. }\end{array}$ \\
\hline X4_375 & $\begin{array}{l}\text { John, the state treasurer, does not seek open public bidding for a state construction } \\
\text { contract valued at } \$ 500,000 \text {. }\end{array}$ \\
\hline X4_323 & $\begin{array}{l}\text { John, a county animal control officer, knowingly lets a researcher use a captured stray } \\
\text { dog to see whether the dog dies more quickly by an electric shock or cutting off his head. }\end{array}$ \\
\hline X4_307 & John hosts weekly dog fights and collects bets on the fights. \\
\hline X4_325 & $\begin{array}{l}\text { John, intending to avoid paying taxes, fails to declare } \$ 100,000 \text { of income, which he has } \\
\text { hidden away in an off-shore account. }\end{array}$ \\
\hline X4_337 & $\begin{array}{l}\text { John possesses a month's worth of oxycontin (a prescription painkiller) without a } \\
\text { prescription for it. }\end{array}$ \\
\hline X4_420 & $\begin{array}{l}\text { John sells } 10 \text { doses of very strong heroin to a known drug addict. That drug addict } \\
\text { overdoses on the heroin and dies as a result. }\end{array}$ \\
\hline X0_307 & $\begin{array}{l}\text { John, an election official, threatens to punch a voter unless the voter votes for a particular } \\
\text { candidate. }\end{array}$ \\
\hline X0_311 & John knowingly gives his mother a drug prescribed to him. His mother dies as a result. \\
\hline X0_316 & $\begin{array}{l}\text { John, a lawyer, purposely turns over secret court transcripts from police informants to } \\
\text { members of a gang, with the intent of having the gang members attack the police } \\
\text { informants. }\end{array}$ \\
\hline X0_324 & $\begin{array}{l}\text { John knowingly sells a cow known to have "mad cow" disease, dangerous to the lives of } \\
\text { both humans and animals. }\end{array}$ \\
\hline X0_325 & $\begin{array}{l}\text { John knowingly picks up a homeless man in Atlantic County and gives him a ride to } \\
\text { Camden county where he leaves him, without permission from either county welfare } \\
\text { board. }\end{array}$ \\
\hline X0_327 & $\begin{array}{l}\text { John willfully lies on his dental license application by denying that he previously held a } \\
\text { dental license in New York, when he did. }\end{array}$ \\
\hline X0_350 & $\begin{array}{l}\text { John knowingly agrees to buy a } \$ 600,000 \text { house with a mortgage in his own name for a } \\
\text { known drug dealer who pays John back in cash. }\end{array}$ \\
\hline X0_351 & $\begin{array}{l}\text { John, a government contractor, knowingly lies about his professional certifications in } \\
\text { negotiations for a } \$ 30,000 \text { contract. }\end{array}$ \\
\hline X0_353 & $\begin{array}{l}\text { John knowingly digs up a grave and moves a person's remains to another location } \\
\text { without permission. }\end{array}$ \\
\hline
\end{tabular}




\begin{tabular}{|c|c|}
\hline & \\
\hline X0_362 & $\begin{array}{l}\text { John, who works for the local zoning board, finds out through his job that a residential } \\
\text { area has just been rezoned to have a diner, which would increase residential property } \\
\text { values. The information is not yet public, but John knowingly purchases a house nearby, } \\
\text { with the increase in property value (and thus his gain) being } \$ 10,000\end{array}$ \\
\hline X0_366 & $\begin{array}{l}\text { John calls a movie theater and makes a bomb threat, knowing that the theater will be } \\
\text { evacuated, and in the hysteria during the evacuation, one person is trampled to death. }\end{array}$ \\
\hline X0_367 & John knowingly rents an obscene video to a 25 -year-old man. \\
\hline X0_369 & $\begin{array}{l}\text { John knowingly conspires with two other people to import LSD into New Jersey and will } \\
\text { oversee other people selling the LSD. }\end{array}$ \\
\hline X0_371 & John, an adult, knowingly gives a glass bong to a person under the age of 18 . \\
\hline X0_376 & John knowingly has a rifle in his house without a proper firearms permit. \\
\hline X0_395 & $\begin{array}{l}\text { John knowingly has a marijuana operation which has produced } 60 \text { pounds (about } 13,600 \\
\text { doses) of marijuana, with a street value of } \$ 180,000 \text {. }\end{array}$ \\
\hline X0_397 & John knowingly manufactures one ounce of the drug crystal meth. \\
\hline X0_400 & $\begin{array}{l}\text { John knowingly lends a gun, which has been used by him and various other members of a } \\
\text { gang to commit muggings, to his friend. }\end{array}$ \\
\hline X0_403 & $\begin{array}{l}\text { John, an employer, requires an applicant to submit to a lie detector test before allowing } \\
\text { that applicant to be considered for a secretary opening. }\end{array}$ \\
\hline X1_321 & John knowingly drives with a revoked license, for the third time. \\
\hline X1_324 & John knowingly sells a purse made out of dog fur. \\
\hline X1_329 & $\begin{array}{l}\text { John stands outside of a train station and offers to sell Amtrak tickets to another man, } \\
\text { without having written permission from Amtrak to do so. }\end{array}$ \\
\hline $\mathrm{X} 1 \_330$ & John cheats at a casino by hiding cards in his sleeve and manages to win $\$ 80,000$. \\
\hline X1_339 & $\begin{array}{l}\text { John purposely gives another person lethal drugs to help that person kill himself (commit } \\
\text { suicide). }\end{array}$ \\
\hline X1_343 & $\begin{array}{l}\text { John knowingly smashes the lights on an airplane landing strip, so that airplanes are } \\
\text { unable to land. }\end{array}$ \\
\hline X1_348 & John earns a living by making illegal loans at interest rates above those allowed by law. \\
\hline X1_353 & $\begin{array}{l}\text { John intentionally forges an organ donor document for a deceased person in exchange for } \\
\text { payment from a potential recipient. }\end{array}$ \\
\hline X1_358 & $\begin{array}{l}\text { John, who is trying to avoid being arrested, purposely threatens to beat up someone who } \\
\text { might reveal his location to police. }\end{array}$ \\
\hline X1_365 & $\begin{array}{l}\text { From prison, John writes a letter to his best friend pressuring him to join his gang and to } \\
\text { begin selling drugs for the gang. }\end{array}$ \\
\hline X1_369 & John knowingly grows 15 marijuana plants in his greenhouse. \\
\hline X1_374 & John purposely hides another person who is suspected of bombing a train, which resulted \\
\hline
\end{tabular}




\begin{tabular}{|c|c|}
\hline & in the death of a \\
\hline $\mathrm{X} 1 \_375$ & John illegally wears a bullet-proof vest during an attempt to kill his neighbor. \\
\hline $\mathrm{X} 1 \_377$ & $\begin{array}{l}\text { John, a fraternity member, knowingly pours boiling water on another person, causing } \\
\text { severe injuries. }\end{array}$ \\
\hline X1_387 & $\begin{array}{l}\text { John, a doctor, knowingly submits invoices to an insurance company for care that he } \\
\text { knows he didn't provide to the insured patient. }\end{array}$ \\
\hline X1_396 & John knowingly has a marijuana growing operation with 30 marijuana plants. \\
\hline X1_397 & $\begin{array}{l}\text { John knowingly has } 1 \text { gram of morphine outside of a medical facility and without a } \\
\text { prescription. }\end{array}$ \\
\hline $\mathrm{X} 1 \_400$ & $\begin{array}{l}\text { A pawnbroker knowingly offers to sell a pistol with a mother of pearl handle to a man } \\
\text { who comes into his store. }\end{array}$ \\
\hline X1_402 & $\begin{array}{l}\text { A hardware store knowingly sells oil-burning camping stoves which do not have safety } \\
\text { valves that shut off the stoves if they tip over, creating a risk for a fire. }\end{array}$ \\
\hline X2_308 & $\begin{array}{l}\text { John, who has been disqualified from voting, nevertheless knowingly votes at an } \\
\text { election. }\end{array}$ \\
\hline $\mathrm{X} 2 \_313$ & $\begin{array}{l}\text { A public utility company knowingly imports enriched uranium (radioactive material) into } \\
\text { New Jersey, which is illegal under New Jersey law. }\end{array}$ \\
\hline $\mathrm{X} 2 \_318$ & $\begin{array}{l}\text { For the second time in } 10 \text { years, John knowingly receives Medicaid benefits totaling } \\
\$ 2000 \text { after having been kicked out of the Medicaid program. }\end{array}$ \\
\hline $\mathrm{X} 2 \_319$ & $\begin{array}{l}\text { John knowingly pays a construction worker to fix his house "under the table" (without } \\
\text { collecting and paying proper taxes), paying the worker } \$ 80,000 \text { for the contracted work. }\end{array}$ \\
\hline $\mathrm{X} 2 \_323$ & $\begin{array}{l}\text { John knowingly drives a car through a school zone while drunk (with a blood alcohol } \\
\text { concentration of . } 09 \% \text {, above the legal limit). This is John's third offense of this kind. }\end{array}$ \\
\hline $\mathrm{X} 2 \_340$ & $\begin{array}{l}\text { John knowingly assists in cloning a human being. (Cloning means using a human cell's } \\
\text { genetic material to create a new human.) }\end{array}$ \\
\hline $\mathrm{X} 2 \_343$ & John knowingly starts a fire in a church. \\
\hline X2_348 & $\begin{array}{l}\text { In applying for a driver's license, John knowingly presents a forged birth certificate as } \\
\text { proof of identity. }\end{array}$ \\
\hline $\mathrm{X} 2 \_349$ & John knowingly sells another person a forged birth certificate. \\
\hline X2_350 & $\begin{array}{l}\text { John knowingly sells pirated CD's on the subway. This is John's second offense of this } \\
\text { type. }\end{array}$ \\
\hline $\mathrm{X} 2 \_359$ & John agrees to accept new sneakers, valued at $\$ 100$, in return for not reporting a crime. \\
\hline $\mathrm{X} 2 \_360$ & John, who is incarcerated, knowingly makes a knife that can be used for escaping. \\
\hline $\mathrm{X} 2 \_361$ & John threatens to hurt a juror in an attempt to influence the jury in a murder trial. \\
\hline X2_368 & $\begin{array}{l}\text { John allows a } 16 \text { year old to enter a theater showing an obscene film knowing that the } \\
\text { person is only } 16 \text { years old. }\end{array}$ \\
\hline$X 2 \_376$ & John holds a baseball bat with the intention of damaging his neighbor's new car. \\
\hline
\end{tabular}




\begin{tabular}{|c|c|}
\hline $2 \_377$ & $\begin{array}{l}\text { John opens a bottle of ketchup at the supermarket and places it back on the shelf without } \\
\text { purchasing it. }\end{array}$ \\
\hline X2_378 & A hospital knowingly fails to pay the wages of its unionized nurses on time. \\
\hline $\mathrm{X} 2 \_382$ & John, an adult, hires a 15 year old to help him steal a car. \\
\hline $\mathrm{X} 2 \_383$ & $\begin{array}{l}\text { John knowingly hacks into a company's computer network to access company e-mail and } \\
\text { then posts the emails online for the public to see }\end{array}$ \\
\hline X2_385 & John makes a $\$ 5000$ loan to Sam and knowingly charges him a 55\% interest rate. \\
\hline X2_392 & $\begin{array}{l}\text { John knowingly interferes with a police dog search at the airport by giving treats to the } \\
\text { dog. }\end{array}$ \\
\hline X2_398 & John knowingly manufactures one gram (20000 doses) of the drug LSD. \\
\hline X2_402 & $\begin{array}{l}\text { John knowingly buys a handgun and carries it around with him, but he does not have a } \\
\text { permit for the gun. }\end{array}$ \\
\hline $\mathrm{X} 2 \_403$ & $\begin{array}{l}\text { A hardware store knowingly sells oil-burning camping stoves that create so much carbon } \\
\text { dioxide when they are used that they become hazardous. }\end{array}$ \\
\hline X3_307 & John threatens to punch another man if the man registers to vote in the next election. \\
\hline X3_308 & $\begin{array}{l}\text { John offers to pay for Super Bowl tickets for someone if that person votes for John's } \\
\text { preferred Presidential candidate. }\end{array}$ \\
\hline X3_311 & $\begin{array}{l}\text { John, a doctor, uses a false name on a } \\
\text { prescription in order to obtain drugs for personal use. }\end{array}$ \\
\hline X3_315 & John possesses a device designed to intercept private telephone calls. \\
\hline X3_331 & $\begin{array}{l}\text { John uses a calculator that is specifically programmed to help him count cards at a casino } \\
\text { and manages to win } \$ 100,000 \text {. }\end{array}$ \\
\hline X3_332 & $\begin{array}{l}\text { John holds a legally purchased lottery ticket which cost } \$ 3 \text { and sells his friend the right to } \\
\text { have half of the ticket's winnings for } \$ 3,000 \text {. }\end{array}$ \\
\hline X3_341 & $\begin{array}{l}\text { John intentionally snatches a politician from the street and holds him in a truck with } \\
\text { blacked-out windows to prevent that politician from voting on a law. }\end{array}$ \\
\hline X3_342 & $\begin{array}{l}\text { As a driver is stopped at a traffic light in his car, John opens the door, pulls the driver } \\
\text { from his seat, and drives the car away. }\end{array}$ \\
\hline X3_343 & $\begin{array}{l}\text { John recklessly keeps a lot of flammable liquid in his kitchen next to his gas stove. If the } \\
\text { flammable liquid were to catch fire it could cause widespread damage to properties } \\
\text { around his house, but John continues to use his stove in spite of the risk. }\end{array}$ \\
\hline X3_346 & John hacks into his ex-girlfriend's computer to get her bank account details. \\
\hline X3_349 & $\begin{array}{l}\text { John owns paper, a machine, and seal that he knows can be used to make forged birth } \\
\text { certificates. }\end{array}$ \\
\hline X3_350 & $\begin{array}{l}\text { John, a lawyer, hires someone to try to convince patients at an emergency room to hire } \\
\text { John for a personal injury law suit. }\end{array}$ \\
\hline X3_352 & $\begin{array}{l}\text { John, a patient, knowingly makes } 6 \text { fraudulent health insurance claims, which add up to } \\
\$ 2000 \text {. }\end{array}$ \\
\hline
\end{tabular}




\begin{tabular}{|c|c|}
\hline K3_355 & $\begin{array}{l}\text { John, an accused murderer, threatens to hurt a potential witness in his murder trial, to try } \\
\text { to ensure that the witness will not testify against John. }\end{array}$ \\
\hline X3_357 & $\begin{array}{l}\text { John, a prison guard, gives a cell phone to an inmate, knowing that cell phones are not } \\
\text { allowed in prison. }\end{array}$ \\
\hline X3_359 & $\begin{array}{l}\text { John offers a witness a new laptop, valued at } \$ 700 \text {, in return for the witness not reporting } \\
\text { John for a crime. }\end{array}$ \\
\hline X3_369 & $\begin{array}{l}\text { John has base materials for making crystal meth, including anhydrous ammonia, and } \\
\text { intends to use it for that purpose. }\end{array}$ \\
\hline X3_370 & John sells 500 doses of a date rape drug ("flunitrazepam") to another person. \\
\hline X3_371 & $\begin{array}{l}\text { John, a manufacturer of glass pipes, places an advertisement in a newspaper, knowing } \\
\text { that the glass pipes are intended for smoking marijuana. }\end{array}$ \\
\hline $\mathrm{X} 3 \_372$ & $\begin{array}{l}\text { For his illegal business collecting bets, John knowingly has in his possession a list of } 6 \text { or } \\
\text { more bets, totaling more than } \$ 1,000 \text {, which were made for a sporting event. }\end{array}$ \\
\hline X3_378 & $\begin{array}{l}\text { John, an attorney, personally visits the damaged homes of tornado victims and offers } \\
\text { them legal services. }\end{array}$ \\
\hline X3_382 & $\begin{array}{l}\text { John, a computer hacker, purposefully breaks into the computer systems of the utility } \\
\text { grid, shutting down electricity for three city blocks. }\end{array}$ \\
\hline X3_384 & John bribes a jockey with $\$ 100,000$ to lose a horse race. \\
\hline X3_396 & John manufactures 10 ounces (about 2800 doses) of c1 \\
\hline X3_397 & John possesses a gram (about two doses) of marijuana \\
\hline X3_398 & $\begin{array}{l}\text { John manufactures } 1 \text { pound (about } 1760 \text { doses) of the illegal substance commonly called } \\
\text { crystal meth. }\end{array}$ \\
\hline X3_399 & $\begin{array}{l}\text { John, a scientist who researches with anthrax, accidentally leaves the door to his } \\
\text { laboratory unlocked one night, allowing an unauthorized person to take a sample of the } \\
\text { anthrax. }\end{array}$ \\
\hline X3_401 & $\begin{array}{l}\text { John has a semi-automatic rifle in his car along with gloves and stockings, because he is } \\
\text { planning to rob a house, taking the gun with him. }\end{array}$ \\
\hline X4_335 & $\begin{array}{l}\text { John uses an extra prescription slip attached to an actual prescription to obtain pain pills } \\
\text { from a pharmacy. }\end{array}$ \\
\hline X4_421 & John possesses half a gram of cocaine, which has a street value of about $\$ 35$. \\
\hline X4_422 & $\begin{array}{l}\text { John possesses } 4 \text { codeine pills (a moderate prescription painkiller), but he does not have a } \\
\text { valid prescription for them. }\end{array}$ \\
\hline X4_423 & $\begin{array}{l}\text { John possesses } 2 \text { ounces of marijuana, which has a street value of about } \$ 500 \text { and is } \\
\text { enough to roll } 100 \text { joints. }\end{array}$ \\
\hline X4_426 & John smokes a marijuana joint while out at a party with some friends. \\
\hline X4_427 & $\begin{array}{l}\text { One of John's friends gives him a marijuana joint. John fails to turn over the joint to the } \\
\text { nearest police officer. }\end{array}$ \\
\hline
\end{tabular}


